\title{
TASK 3.0 - ADVANCED POWER SYSTEMS SUBTASK 3.18 - ASH BEHAVIOR IN POWER SYSTEMS
}

\section{Draft Final Report}

for the period January 1, 1997, through June 30, 1998

(including the semiannual report for the period January 1 - June 30, 1998)

Prepared for:

Federal Energy Technology Center

AAD Document Control

U.S. Department of Energy

PO Box 10940, MS 921-143

Pittsburgh, PA 15236

Cooperative Agreement No. DE-FC21-93MC30097-37

Performance Monitor: Norman Holcombe

Prepared by:

Christopher J. Zygarlicke Donald P. McCollor Michael L. Swanson John P. Kay

Energy \& Environmental Research Center University of North Dakota

PO Box 9018

Grand Forks, ND 58202-9018 


\section{DRAFT}

\section{DISCLAIMER}

This report was prepared as an account of work sponsored by an agency of the United States Government. Neither the United States Government, nor any agency thereof, nor any of their employees makes any warranty, express or implied, or assumes any legal liability or responsibility for the accuracy, completeness, or usefulness of any information, apparatus, product, or process disclosed or represents that its use would not infringe privately owned rights. Reference herein to any specific commercial product, process, or service by trade name, trademark, manufacturer, or otherwise does not necessarily constitute or imply its endorsement, recommendation, or favoring by the United States Government or any agency thereof. The views and opinions of authors expressed herein do not necessarily state or reflect those of the United States Government or any agency thereof.

\section{ACKNOWLEDGMENT}

This report was prepared with the support of the U.S. Department of Energy (DOE) Federal Energy Technology Center, Cooperative Agreement No. DE-FC21-93MC30097. However, any opinions, findings, conclusions, or recommendations expressed herein are those of the author(s) and do not necessarily reflect the views of the DOE.

\section{EERC DISCLAIMER}

LEGAL NOTICE This research report was prepared by the Energy \& Environmental Research Center (EERC), an agency of the University of North Dakota, as an account of work sponsored by the U.S. Department of Energy. Because of the research nature of the work performed, neither the EERC nor any of its employees makes any warranty, express or implied, or assumes any legal liability or responsibility for the accuracy, completeness, or usefulness of any information, apparatus, product, or process disclosed or represents that its use would not infringe privately owned rights. Reference herein to any specific commercial product, process, or service by trade name, trademark, manufacturer, or otherwise does not necessarily constitute or imply its endorsement or recommendation by the EERC. 


\section{TABLE OF CONTENTS}

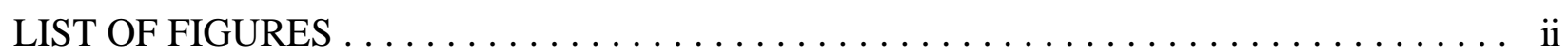

LIST OF TABLES $\ldots \ldots \ldots \ldots \ldots \ldots \ldots \ldots \ldots \ldots \ldots \ldots \ldots \ldots \ldots \ldots \ldots$

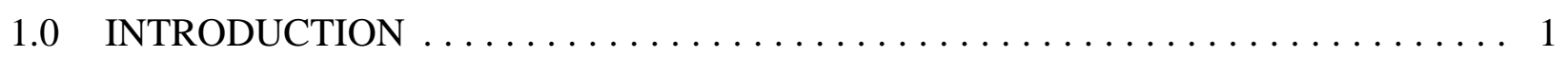

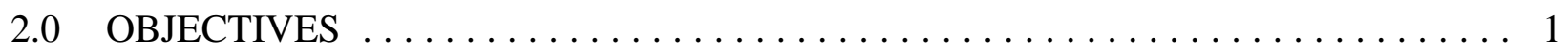

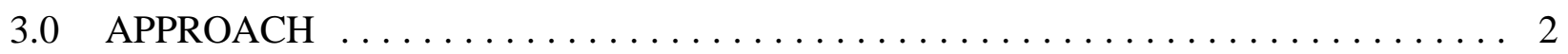

3.1 Task 1 - Critical Issues in Ash Behavior ......................... 2

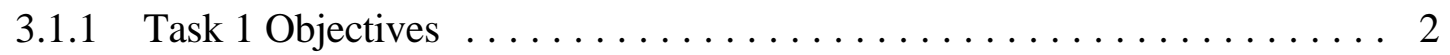

3.1 .2 Task 1 Results . .............................. 2

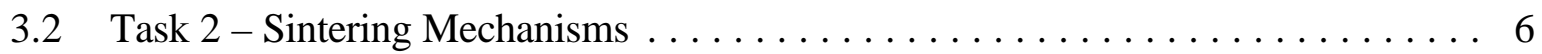

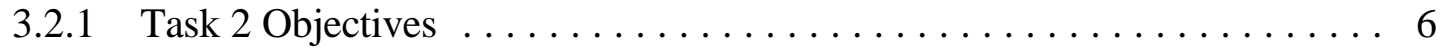

3.2.2 Task 2 Results - Viscosity and Crystallization Relationships ........ 6

3.2.3 Task 2 Results - Sintering Studies Using HSM $\ldots \ldots \ldots \ldots \ldots \ldots$

3.2.3.1 Apparatus . ............................... 7

3.2.3.2 Sintering Material Selection and Preparation $\ldots \ldots \ldots \ldots \ldots \ldots \ldots$

3.2.3.3 Heated-Stage Microscope Operating Procedure $\ldots \ldots \ldots \ldots \ldots \ldots 9$

3.2.3.4 Sample Analysis . . . . . . . . . . . . . . . . . . . . . . 10

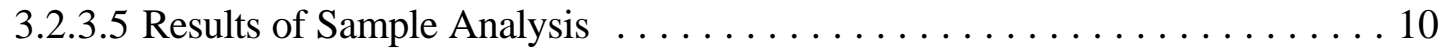

3.2.3.6 HSM Growth Rate Measurements . . . . . . . . . . . . . . . . 14

3.2.3.7 Viscosity Calculation with HSM Measurements . . . . . . . . . . . . 14

3.2.3.8 Discussion . . . . . . . . . . . . . . . . . . . . . . . . 20

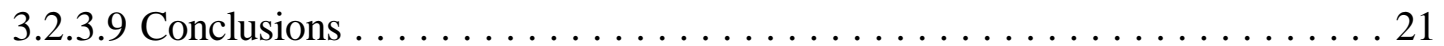

3.3 Task 3 - Ash Deposit Chemistry and Phase Relationships $\ldots \ldots \ldots \ldots \ldots \ldots 21$

3.3.1 Task 3 Objectives ........................... 21

3.3.2 Task 3 Results - Deposit Ash Chemistry and Phase Relationships . . . . . 22

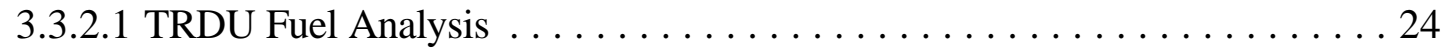

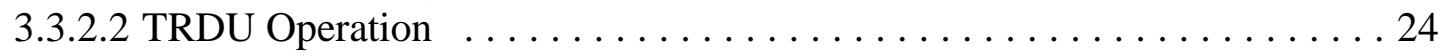

3.3 .2 .3 HGFV Operation .............................. 27

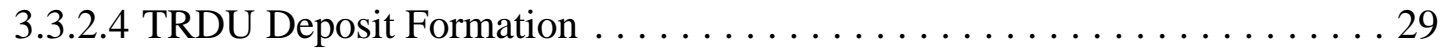

3.3.3 Task 3 Results - Alloy Corrosion $\ldots \ldots \ldots \ldots \ldots \ldots \ldots \ldots \ldots \ldots$

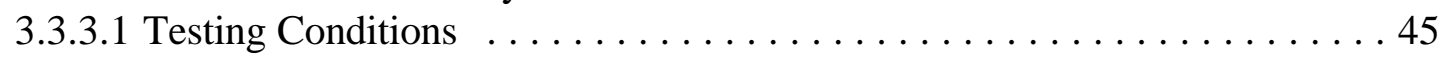

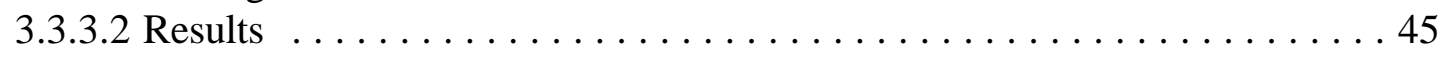

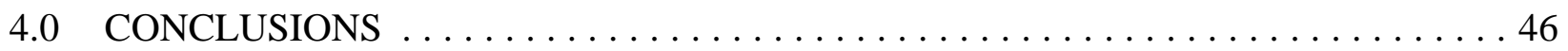

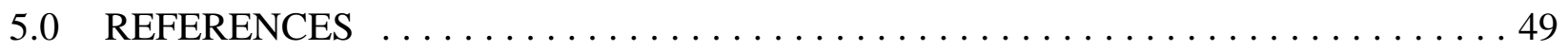

PRELIMINARY SUMMARY OF KEY ISSUES IN ASH BEHAVIOR ....... Appendix A 


\section{DRAFT}

\section{TABLE OF CONTENTS (continued)}

COMPUTED VARIABLES FOR HOPPER MODEL AND MODIFIED

FRENKEL MODEL

Appendix B

\section{LIST OF FIGURES}

1 BP- and Kalmanovitch-predicted viscosity compared to the measured viscosity for

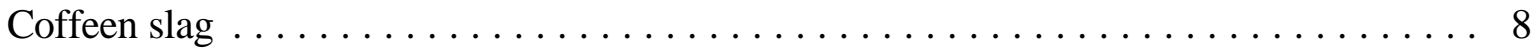

2 BP- and Senior-predicted viscosity compared to measured viscosity for MTI 254 slag . . 8

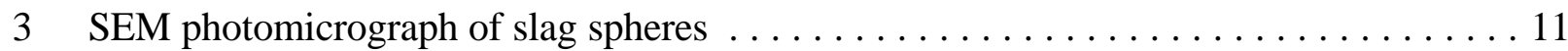

4 SEM photomicrograph of sintered slag spheres $\ldots \ldots \ldots \ldots \ldots \ldots \ldots \ldots \ldots \ldots$

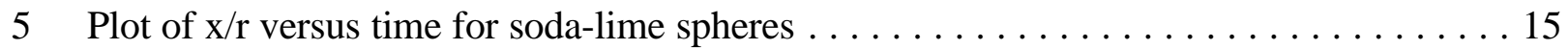

6 Plot of $\mathrm{x} / \mathrm{r}$ versus time for Illinois No. 6 slag spheres $\ldots \ldots \ldots \ldots \ldots \ldots \ldots \ldots \ldots \ldots \ldots \ldots$

7 Plot of $\log _{10}(\eta / T)$ versus $1 / \mathrm{T}$ for the soda-lime glass $\ldots \ldots \ldots \ldots \ldots \ldots \ldots$

8 Plot of $\log _{10}(\eta / T)$ versus $1 /$ T for the Illinois No. 6 slag $\ldots \ldots \ldots \ldots \ldots \ldots$

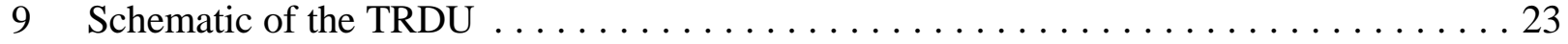

10 SEM photomicrograph of TRDU deposit showing Points $1-3 \ldots \ldots \ldots \ldots$

11 SEM photomicrograph of TRDU deposit showing Point $6 \ldots \ldots \ldots \ldots \ldots$

12 SEM photomicrograph of a deposit from the mixing zone of the TRDU . . . . . . 32

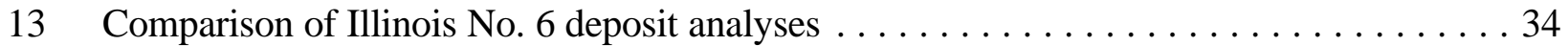

14 Comparison of SEMPC analyses of burner deposits for various fuels tested in TRDU . . 34

15 SEM micrograph of standpipe deposit from gasification test of Wyodak coal . . . . . . 41

16 SEM micrograph of standpipe deposit from gasification test of Wyodak coal . . . . . . 41

continued 


\section{LIST OF FIGURES (continued)}

17 SEM micrograph of mixing zone deposit from gasification test on Wyodak coal . . . . . 42

18 SEM micrograph of mixing zone deposit from gasification test on Wyodak coal . . . . . 42

19 SEM micrograph of mixing zone deposit from gasification test of Illinois No. 6 coal . . . 43

20 SEM micrograph of mixing zone deposit from gasification test of Illinois No. 6 coal . . . 43

21 SEM micrograph of standpipe deposit material from the combustion test of

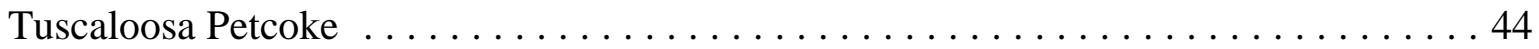

22 SEM micrograph of standpipe deposit material from the combustion test of

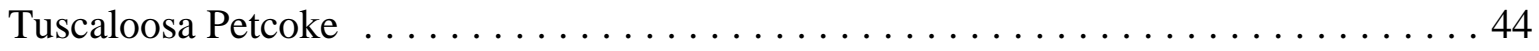

\section{LIST OF TABLES}

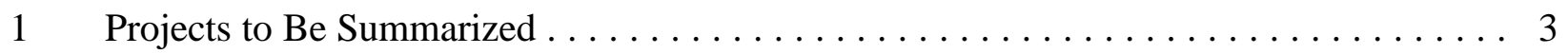

2 Summary of Key Issues in Ash Behavior $\ldots \ldots \ldots \ldots \ldots \ldots \ldots \ldots \ldots$

3 Composition of the Coal Ash Slags Used in the Validation of the Neural

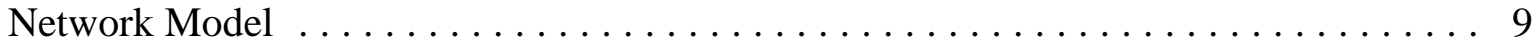

4 Chemistry of Glass Spheres and Illinois No. 6 Slag $\ldots \ldots \ldots \ldots \ldots \ldots \ldots \ldots$

5 Analysis of Illinois No. 6 Slag Spheres $\ldots \ldots \ldots \ldots \ldots \ldots \ldots \ldots \ldots \ldots \ldots \ldots \ldots$

6 Analysis of HSM-Sintered Illinois No. 6 Slag Spheres $\ldots \ldots \ldots \ldots \ldots \ldots \ldots \ldots$

7 Coefficients for Hopper and Modified Frenkel Equations $\ldots \ldots \ldots \ldots \ldots \ldots$

8 Model Calculations of Soda-Lime Glass and Illinois No. 6 Slag Viscosities . . . . . . . . 19

$9 \quad$ Illinois No. 6, Wyodak, and SUFCo Coals, Tuscaloosa Petcoke, and Plum Run Dolomite Analyses . . . . . . . . . . . . . . . . . . . 25

10 Summary of CCSEM Results for Belle Ayr (Wyodak) Subbituminous Coal . . . . . . 26 


\section{LIST OF TABLES (continued)}

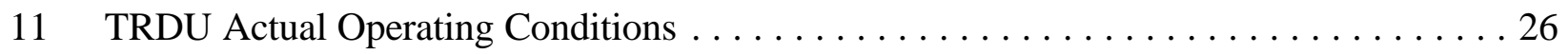

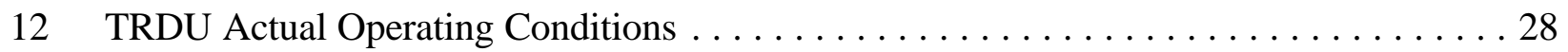

13 XRF Chemical Composition of TRDU Samples Test P051 $(2 / 27 / 97) \ldots . \ldots \ldots$

14 SEM Morphology Analysis of TRDU Riser Deposits from Test P051 . . . . . . . . . 31

15 SEM Morphology Analysis of TRDU Burner Throat Deposits from Test P055 . . . . . . 33

16 SEM Morphology Analysis of TRDU Mixing Zone Deposits from Test P055 . . . . . . 33

17 XRF and SEMPC Data from TRDU Mixing Zone Deposits Formed from

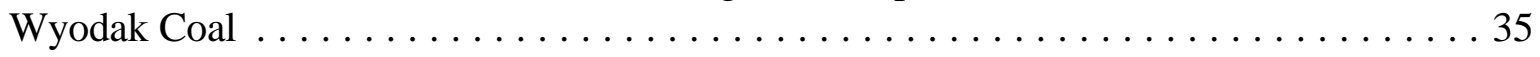

18 Comparison of XRF and SEMPC Data on Burner Deposits from Illinois No. 6 Fuel . . . 35

19 Comparison of XRF and SEMPC Data on Mixing Zone Deposits from SUFCo Fuel . . 36

20 SEM Morphology Analysis of TRDU Standpipe Deposits from Wyodak Coal Gasification Test P056 2/21/98 (Sample 98-0403) . . . . . . . . . . . . . . . . . 37

21 SEM Morphology Analysis of TRDU Burner Deposits from SUFCo Coal Gasification Test P057 4/5/98 (Sample 98-0400) . . . . . . . . . . . . . . . 37

22 SEM Morphology Analysis of TRDU Burner Deposits from Wyodak Coal Gasification Test P057 (Sample 98-0404) . . . . . . . . . . . . . . . . . 38

23 SEM Morphology Analysis of TRDU Burner Deposits from Illinois No. 6 Coal Gasification Test P056 (Sample 98-0402) . . . . . . . . . . . . . . . . . . 39

24 SEM Morphology Analysis of TRDU Disengager Deposit from Tuscaloosa Petcoke

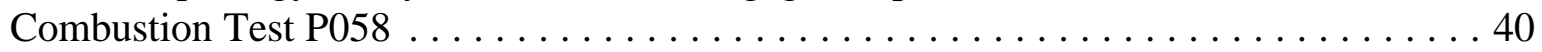

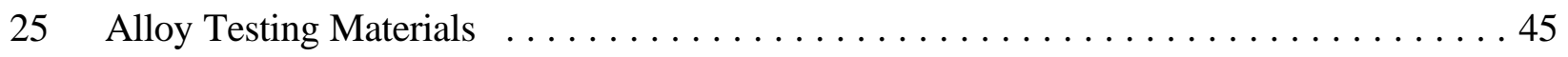




\section{DRAFT}

\section{TASK 3.0 - ADVANCED POWER SYSTEMS SUBTASK 3.18 - ASH BEHAVIOR IN POWER SYSTEMS}

\subsection{INTRODUCTION}

Advanced power systems such as integrated gasification combined cycle and fluidized-bed combustion (FBC) systems are at the forefront of power industry research because of the need for increased efficiency and reduction of greenhouse gases. Ash behavior in power systems can have a significant impact on the design and performance of these systems. The Energy \& Environmental Research Center (EERC) has developed a focused research initiative aimed at filling gaps in the understanding of fundamental mechanisms of ash behavior, which has relevance to commercial application and marketable products associated with advanced power systems. This program develops methods and means to better understand and mitigate adverse coal ash behavior in advanced power systems and can act to relieve the U.S. reliance on diminishing recoverable oil resources and other greenhouse gas-producing fossil fuels.

\subsection{OBJECTIVES}

The overall goal of this initiative is to develop fundamental knowledge of ash behavior in power systems for the purpose of increasing power production efficiency, reducing operation and maintenance costs, and reducing greenhouse gas emissions into the atmosphere. The specific objectives of this initiative focus primarily on ash behavior related to advanced power systems and include the following:

- Determine the current status of the fundamental ash interactions and deposition formation mechanisms as already reported through previous or ongoing projects at the EERC or in the literature.

- Determine sintering mechanisms for temperatures and particle compositions that are less well known and remain for the most part undetermined.

- Identify the relationship between the temperature of critical viscosity $\left(\mathrm{T}_{\mathrm{cv}}\right)$ as measured in a viscometer and the crystallization occurring in the melt.

- Perform a literature search on the use of heated-stage microscopy (HSM) for examining in situ ash-sintering phenomena and then validate the use of HSM in the determination of viscosity in spherical ash particles.

- Ascertain the formation and stability of specific mineral or amorphous phases in deposits typical of advanced power systems.

- Evaluate corrosion for alloys being used in supercritical combustion systems. 


\subsection{APPROACH}

Subtask 3.18 is structured as three tasks. Task 1 pertains to summarizing the critical issues in ash behavior, especially for advanced power systems. Task 2 focuses on fundamental ash sintering and viscosity-ash composition relationships that are critical for developing a better mechanistic understanding of ash deposit formation and for predicting ash behavior. Task 3 is aimed primarily at determining the role of the ash chemistry and phase relationships for specific ash interactions in advanced power systems. The role of sulfides in the formation of ash deposits in gasification systems and the factors that influence alloy corrosion in supercritical boilers will be specifically analyzed.

The primary questions that are being addressed in Subtask 3.18 and the scientific approach to finding potential answers to the questions and achieving the objectives of the project are outlined below by task.

\subsection{Task 1 - Critical Issues in Ash Behavior}

\subsubsection{Task 1 Objectives}

Over the past 25 years, the EERC has studied various aspects of ash behavior in combustion and gasification power systems. The results of the different projects that have been undertaken to understand ash behavior in advanced power systems need to be synthesized into a cohesive report that can be used as a synopsis of the current status of the EERC knowledge base. This information, coupled with a review of literature on ash behavior in advanced power systems from sources outside the EERC, provides excellent focus and direction to this project. Key questions addressed in this task are as follows:

- What are the critical issues and the current status in understanding ash behavior for advanced power systems?

- Does the EERC already have mechanistic information on ash behavior for advanced power systems or for reducing conditions in general that can be used to enhance the structured initiative?

- What are some key studies in the literature that relate to advanced power system deposits?

\subsubsection{Task 1 Results}

The EERC has generated a wealth of data through several research projects in the last few years that need to be summarized and reported concisely and distributed to key personnel. The summary report and a selective survey of key literature relating to ash behavior for advanced power systems will provide a sound basis for determining the status of current knowledge and understanding of ash behavior for advanced systems. Projects at the EERC to develop critical information pertaining to ash deposition mechanisms in gasification or reducing environments are 


\section{DRAFT}

given in Table 1. Some of the project information that is proprietary is not disclosed; however, the fundamental mechanistic principles for ash formation and behavior established through these projects are available for review and summary.

TABLE 1

Projects to Be Summarized

\begin{tabular}{|c|c|}
\hline Project Name & Description \\
\hline $\begin{array}{l}\text { Coal Ash Behavior in Reducing Environments } \\
\text { (CABRE) }\end{array}$ & $\begin{array}{l}\text { Study of laboratory and full-scale entrained- } \\
\text { flow gasifier-type deposits, deposit } \\
\text { mechanisms, and novel analytical methods }\end{array}$ \\
\hline $\begin{array}{l}\text { DOE }^{1} \text { Cooperative Agreement - Alkali Capture } \\
\text { in Advanced Power Systems }\end{array}$ & $\begin{array}{l}\text { Alkali formation and capture in advanced } \\
\text { power systems }\end{array}$ \\
\hline $\begin{array}{l}\text { DOE Cooperative Agreement - The EERC } \\
\text { Transport Reactor Demonstration Unit }\end{array}$ & $\begin{array}{l}\text { Demonstration of a pilot-scale pressurized } \\
\text { fluidized-bed gasifier }\end{array}$ \\
\hline $\begin{array}{l}\text { DOE Cooperative Agreement - The Fuel } \\
\text { Quality Advisor }\end{array}$ & $\begin{array}{l}\text { Development of ash deposition and coal- } \\
\text { handling predictive models within a user- } \\
\text { friendly computer platform }\end{array}$ \\
\hline $\begin{array}{l}\text { DOE Cooperative Agreement - Fuel Utilization } \\
\text { Properties }\end{array}$ & $\begin{array}{l}\text { Fundamental properties of entrained ash } \\
\text { deposit formation in combustion and in } \\
\text { reducing environments }\end{array}$ \\
\hline Hot-Gas Filter Ash Characterization Project & $\begin{array}{l}\text { Characteristics of ash material in hot-gas } \\
\text { filters and formation mechanisms for filter- } \\
\text { blinding deposits. }\end{array}$ \\
\hline Fireside Performance Indices Project & $\begin{array}{l}\text { Predictive indices formulated for coal-fired } \\
\text { boilers that assess ash deposition potential } \\
\text { and stack gas opacity }\end{array}$ \\
\hline Fluidized-Bed Combustion Agglomeration & $\begin{array}{l}\text { Determination of key mechanisms for bed } \\
\text { agglomeration in systems }\end{array}$ \\
\hline Project Calcium & $\begin{array}{l}\text { Mechanistic algorithms and predictive } \\
\text { software for predicting ash deposition from } \\
\text { high-calcium coals }\end{array}$ \\
\hline Project Sodium & $\begin{array}{l}\text { Low-rank coal fouling deposit formation, } \\
\text { especially for western fuels, and the role of } \\
\text { sodium in the formation of ash deposits }\end{array}$ \\
\hline
\end{tabular}

${ }^{1}$ Department of Energy. 


\section{DRAFT}

Summaries of the current knowledge of key ash transformation issues along with references to applicable EERC project information and seminal literature articles are given in Appendix A. Combustion and gasification processes are seen as being sufficiently different to warrant separate treatment, although some redundancy will occur. The entry for each key issue will consist of the level of research priority, a short description of the issue and its relevance, a ranking of EERC expertise on the issue and research project results, a statement of unanswered research questions, a synopsis of current knowledge, and a listing of associated references. Some of the references contain abstracts of key information.

A summary of key issues with a relative ranking of research priority and the expertise of the EERC with each issue is given in Table 2. It is apparent from the current and previous analysis of work performed on ash behavior that there is a wealth of information on the mechanisms of ash formation and deposition in conventional coal-fired power systems. It is in this area also that the greatest EERC expertise is centered, the result of years of research experience with such systems.

The unanswered research questions involving conventional power systems fall into two general categories. The first involves obtaining more quantitative relationships for ash behavior for which the quantitative mechanism is known in order to better predict real-world ash deposition behavior and better model combustion systems. An example of this is the issue of relating ash viscosity and size to actual deposition rates seen in a utility boiler. The second category is the extension of proven analysis and ash deposition mechanisms to fuels outside the traditional mainstream, an example being the extension of chemical fractionation and combustion models to tropical coals containing soluble silicon, aluminum, and iron species.

\section{TABLE 2}

Summary of Key Issues in Ash Behavior

\begin{tabular}{lcc}
\hline Issue & $\begin{array}{c}\text { Research } \\
\text { Priority }\end{array}$ & $\begin{array}{c}\text { EERC } \\
\text { Expertise }\end{array}$ \\
\hline Coal Grindability & 2 & 4 \\
Coal Organic Mineral Analysis & 2 & 5 \\
CCSEM $^{1}$ Mineral Determination & 3 & 5 \\
High-Temperature Combustion Deposition & 3 & 5 \\
Low-Temperature Combustion Deposition & 3 & 5 \\
High-Temperature Gasification Deposition & 5 & 3 \\
Low-Temperature Gasification Deposition & 5 & 3 \\
Ash and Deposit Radiative Properties & 4 & 3 \\
Ash and Deposit Thermal Conductivity & 4 & 3 \\
\hline${ }^{1}$ Computer-controlled scanning electron microscopy & &
\end{tabular}




\section{DRAFT}

The issues impacting conventional combustion systems seen as having the highest priority are the prediction of ash and deposit thermal convective and radiative properties. The chemical composition of ash is only indirectly related to the deposit thermal conductivity, with conductivity strongly dependent on deposit particle size, porosity, and degree of sintering. Further, deposit conductivity exhibits hysteresis due to sintering or slagging at elevated temperature. Prediction of deposit conductivity is difficult, requiring knowledge of the thermal history of the deposit as well as an estimation of the change in deposit physical properties with temperature. Ash emissivity strongly increases with decreasing particle size, with chemical composition again having only an indirect effect. Measurements of actual surface emissivities simulating those on an actual boiler wall are difficult to recreate at the bench or pilot scale. To date, no good prediction of ash and deposit emissivity from coal ash physical and chemical properties is available, although qualitative accounts of highly reflective ash from several subbituminous coals have been invoked to explain lack of heat transfer in the lower furnace box of utility boilers.

Both thermal conductivity and emissivity remain the most difficult ash and deposit properties to model. However, these are of key importance to developing quantitative models for conventional power systems. The EERC is currently pursuing a program of bench-scale experiments, with the goal of developing an initial method of predicting ash emissivity from coal mineral properties.

The emphasis on advanced, highly efficient power systems gives the issues of high- and low-temperature deposition in gasification systems the highest research priority. For advanced power systems, fundamental mechanistic information pertaining to ash behavior is sporadic, and much of the research that has been performed in this area has been proprietary and excluded from the public literature. Experimental measurements of full-scale gasifier environments are difficult because of the temperature, pressure, and gas environment encountered. These conditions also ensure that it is very difficult to nearly impossible to simulate ash transformation processes under gasification conditions in pilot- or bench-scale systems. Although the EERC expertise of these mechanisms is limited, it reflects the general state of knowledge in this area and is probably equal to any other research facility. Besides years of operating experience with the EERC pilot-scale slagging gasifier and the EERC entrained-flow gasifier (transport reactor demonstration unit [TRDU]), the EERC has been one of very few facilities to successfully conduct ash transformation tests under gasification conditions in pressurized bench-scale reactors.

Overall, the state of understanding of ash transformation and deposition mechanisms under gasification conditions is two or more decades behind that for conventional power systems. Of highest priority is the development of a conceptual framework from existing experimental protocol which qualitatively outlines the entire ash transformation mechanism in a manner analogous to that for conventional combustion systems. Once this framework is in place, experiments can be targeted at understanding specific features of the process. 


\section{DRAFT}

\subsection{Task 2 - Sintering Mechanisms}

\subsubsection{Task 2 Objectives}

Despite the importance of ash physical properties, specifically viscosity, in the temperature range where boiler fouling and wall slagging occur, there is an almost complete lack of experimental measurements in this range. The viscosity range of interest where fouling occurs for conventional and advanced power systems is $10^{5}$ to $10^{8}$ poise. The non-Newtonian behavior and the presence of both solid and liquid phases make interpretation and modeling of the ash behavior particularly difficult. Existing models based on lower viscosities at higher temperatures are used, although not known to be strictly applicable. Further, the relationship of ash properties to realworld fouling and slagging behavior is known in only a qualitative way, seriously hampering understanding of ash behavior in real-world combustion and gasification systems. One objective in Task 2 is to achieve the ability to better predict fouling and slagging behavior under oxidizing conditions from coal and ash mineral composition, which will significantly enhance the ability of the EERC to assist commercial clients with urgent problems related to ash deposition. It is hoped that the database of information currently available and the information added to it from this work will result in a better predictive model, eventually also applied to reducing environments typical of advanced power systems.

Some of the key questions answered in this task relating to ash deposit sintering mechanisms and viscosity include the following:

- Can the distribution of solids and liquids in a slag be predicted using thermodynamic calculations?

- Does the amount of crystalline phase present regulate the viscosity, or does the resultant residual glassy material describe the viscosity?

\subsubsection{Task 2 Results - Viscosity and Crystallization Relationships}

Measurements of fundamental ash properties of ash slag were performed using heated-stage $\mathrm{x}$-ray diffractometry on ash slag that had previously been characterized for viscositytemperature-composition relationships. The ash slag was heated to a molten state and then cooled through the temperature of critical viscosity and the crystallization path determined. This information was compared to phase diagrams of the principle chemical constituents to determine if the crystallization path followed in the slag is that found in pure compounds. This information is also being used to enhance viscosity models that have been developed at the EERC.

Heated-stage x-ray diffraction was performed on six coal slags including a Powder River Basin (PRB) subbituminous coal from the Rochelle mine, a Rochelle coal with fluxing additives, two North Dakota Center mine lignites supposedly having different slagging performances in a conventional cyclone boiler, and two Illinois No. 6 coals, one containing a calcium-fluxing agent additive. A heated-stage x-ray diffraction (XRD) capability is being added to a new Phillips $X^{\prime}$ Pert $\mathrm{X}$-ray diffractometer at the EERC; however, the system was not available for testing 


\section{DRAFT}

during this period. Samples were taken to Oak Ridge National Laboratory and analyzed. Results were disappointing, with only the Rochelle coal slags exhibiting crystalline paths of mineral components. Problems primarily stemmed from inadequate analytical equipment for heating samples and detecting mineral diffraction patterns. The crystalline minerals were indiscernible from the spectra, and a new series of tests in the EERC heated-stage XRD will be proposed for future work.

Empirical models of the composition-temperature-viscosity relationship in coal ash slag exist in the literature. Many of them are applicable to only limited ranges of temperature and composition. Coal ash slags can have an extremely wide variation in composition and encounter a large temperature distribution in the combustor. In an attempt to build a model encompassing a broader temperature and composition range, a back propagation-of-errors (BP) neural network was trained and implemented. The data set used to train and validate the network was culled from the glass, metallurgical, and coal literature. The model was tested on slags of various compositions. To assess the model's effectiveness, the results were compared to two of the more recent viscosity models in the coal ash and slag literature.

Figures 1 and 2 illustrate the performance of the BP neural network built to predict viscosity. The predicted viscosity of the BP neural network is compared to measured viscosity as well as to that generated by a recently developed viscosity model. Table 3 shows the composition of the two coal ash slags used in the validation of the neural network model.

The BP neural network model, along with eight other viscosity models, was incorporated into a computer program, allowing comparative calculation of viscosity by any or all of the models. The model has a user-friendly interface and will accept elemental ash compositions, data files assembled by the user, and the standard scanning electron microscopy point count (SEMPC) data files. Viscosity as a function of temperature is output in separate files for each of the models selected for later use.

\subsubsection{Task 2 Results - Sintering Studies Using HSM}

\subsubsection{Apparatus}

Experimental sintering measurements were performed using a Leitz heated-stage microscope. The apparatus comprised a Leitz Metallux II optical microscope with a water-cooled heating stage rated to $1750^{\circ} \mathrm{C}$, a tantalum (Ta) heating strip, a black-and-white video camera for recording the data, a computer for logging temperatures, and a computer-video mixer to overlay computer data on the video. A 0.4-mm (0.016-in.) Type $\mathrm{S}$ thermocouple attached to the heating strip with high-temperature ceramic cement provided temperature monitoring and control.

As was previously reported, preliminary calibration and sintering tests indicated the need for more precise control of the heated stage. Consequently, a temperature controller was incorporated into the HSM electrical heating system to maintain a near-constant $\left( \pm 5^{\circ} \mathrm{C}\right)$ strip temperature. 


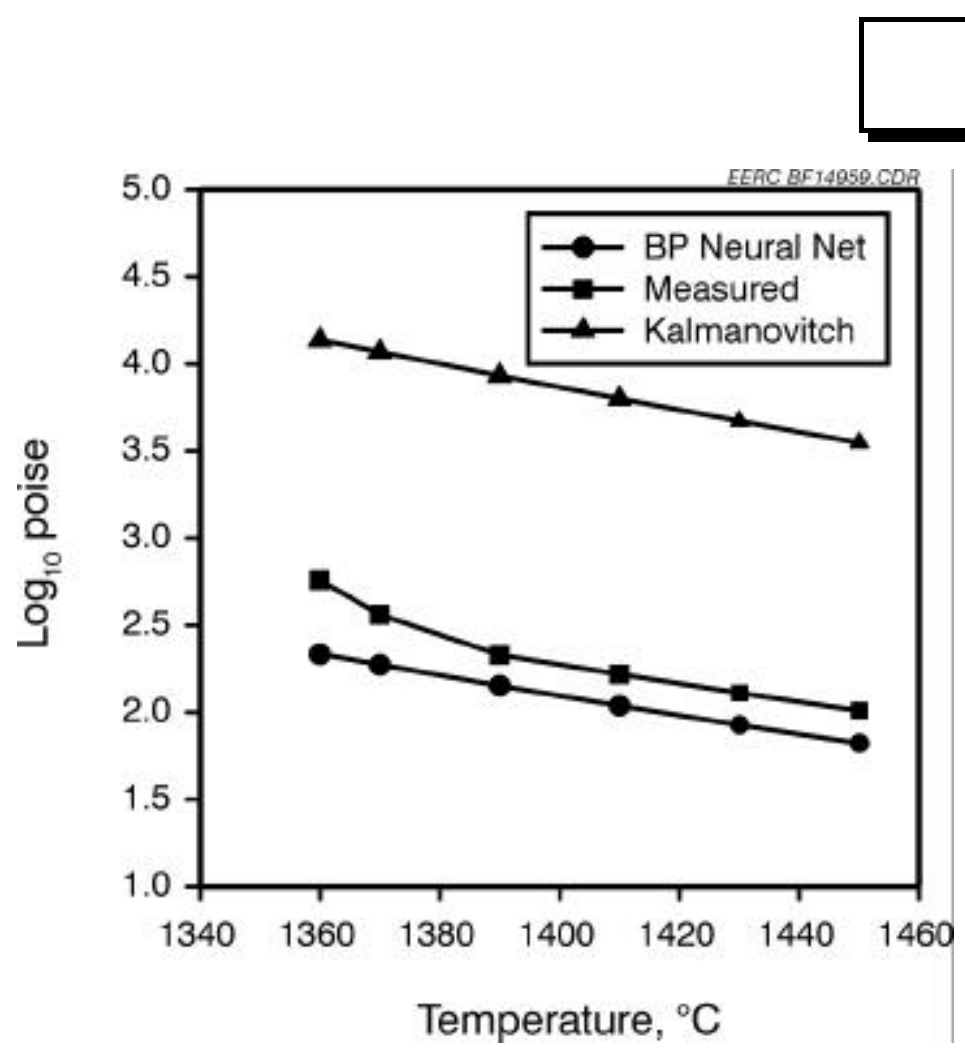

Figure 1. BP- and Kalmanovitch-predicted viscosity compared to the measured viscosity for Coffeen slag.

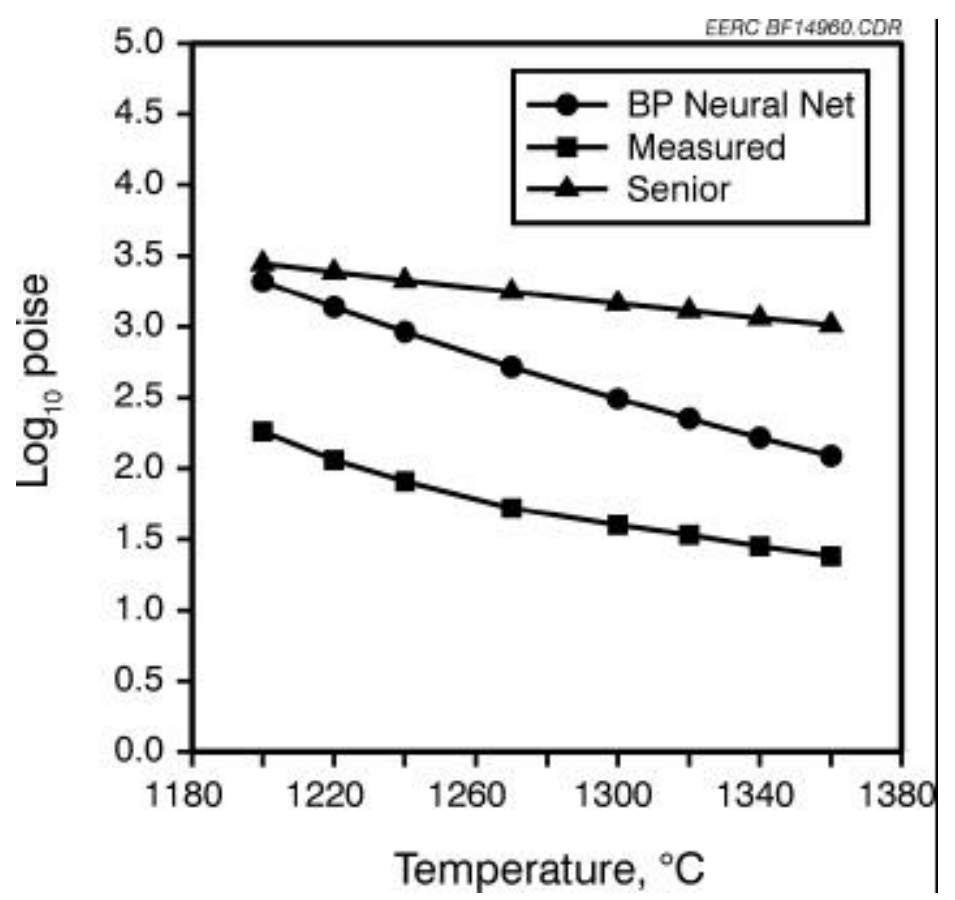

Figure 2. BP- and Senior-predicted viscosity compared to measured viscosity for MTI $254 \mathrm{slag}$. 
TABLE 3

Composition of the Coal Ash Slags Used in the Validation of the Neural Network Model

\begin{tabular}{lrc}
\hline Element, wt $\%$ & Coffeen & MTI 254 \\
\hline $\mathrm{Na}$ & 0.77 & 4.2 \\
$\mathrm{Mg}$ & 1.18 & 3.7 \\
$\mathrm{Al}$ & 16.06 & 15.3 \\
$\mathrm{Si}$ & 52.12 & 50.9 \\
$\mathrm{~K}$ & 1.58 & 1.8 \\
$\mathrm{Ca}$ & 13.19 & 14.2 \\
$\mathrm{Ti}$ & 0.65 & 0.7 \\
$\mathrm{Fe}$ & 14.27 & 8.0 \\
$\mathrm{Ba}$ & 0.00 & 0.0 \\
\hline
\end{tabular}

\subsubsection{Sintering Material Selection and Preparation}

Two materials were used for HSM sintering experiments, a commercial glass of certified composition and a slag produced from the combustion of an Illinois No. 6 bituminous coal. Properties of the model glass, such as viscosity and surface tension, were available in the literature. The bituminous coal has been previously characterized by the EERC.

Preparation of the coal slag for HSM consisted of a three-step process of 1) homogenizing via crushing and reheating, 2) sizing, and 3) spheridizing by passing through a drop-tube furnace (DTF) at $1300^{\circ} \mathrm{C}$ and a residence time of 1.2 seconds. The DTF products were examined by SEM to verify that good sphericity had been obtained. The soda-lime glass was obtained in the form of spheres.

The glass and coal slag spheres were sized using a sonic sieve to two different size ranges: 20-38 $\mu \mathrm{m}$ and 38-50 $\mu \mathrm{m}$. The sintering temperatures of the two materials were identified using HSM. Two particles of similar size were viewed during heating to observe when sintering began and when melting of the spheres occurred. Three temperatures were then chosen (nominally 20-30 degrees less than the onset of sintering temperature). The sintering tests were done on pairs of particles for each size range at the three temperatures.

\subsubsection{Heated-Stage Microscope Operating Procedure}

Particles were transported to the heating strip within the heated-stage microscope on the tip of a needle. The needle was tapped lightly on the surface of the heating strip, depositing many 


\section{DRAFT}

particles on the strip. Several areas were then viewed through the microscope to identify a pair (or pairs) of particles of the same size and in the proper juxtaposition. The computer, video equipment, and heated stage were then prepared for a run. The temperature was ramped at approximately $150^{\circ} \mathrm{C} / \mathrm{min}$ and held at temperature until sintering was well progressed. The heated stage was purged with a slow flow $(10 \mathrm{cc} / \mathrm{min})$ of argon. The temperature logging and video imaging were initiated when the run temperature was attained. The videotape recorder provided a continuous record of the sintering behavior of the particles under observation, with the video mixer superimposing time and temperature data on the video image. Upon completion of a sintering test, the videotape was reviewed and particle radius and neck growth measurements obtained on the selected pairs of sintered particles.

Standard glass beads, $30 \mu \mathrm{m}$ in size, were imaged and recorded prior to sintering tests to provide a size calibration reference. Measurements were taken either from the video monitor or from frame-grabbed images. Calibration of the heated-stage microscope strip temperature was done using standards of known melting points: lead wire $\left(327^{\circ} \mathrm{C}\right)$, sodium sulfate $\left(884^{\circ} \mathrm{C}\right)$, and copper wire $\left(1083^{\circ} \mathrm{C}\right)$. A plot of recorded vs. actual temperature was generated, with a statistical best fit determined. Recorded (thermocouple) temperatures were corrected using the calibration data. Calibrations were checked with sodium sulfate when the heating strip or thermocouple was changed.

\subsubsection{Sample Analysis}

Bulk chemical analysis via $\mathrm{x}$-ray fluorescence $(\mathrm{XRF})$ was performed on the glass spheres and the coal slag spheres. Select samples of the coal slag spheres were viewed by SEM microprobe to determine particle chemistry and homogeneity. Similarly, select sintered slag particles (although not those observed and measured during HSM sintering) were viewed by SEM microprobe to determine neck and particle chemistry.

\subsubsection{Results of Sample Analysis}

Table 4 shows the XRF-determined bulk chemistry of the soda-lime glass spheres and slag spheres that were subjected to sintering via HSM. The slag was formed in the Central Illinois Public Service Coffeen Plant cyclone-fired boiler, which burns Illinois No. 6 bituminous coal. Limestone is blended with the coal prior to combustion to reduce the slag viscosity.

Figures 3 and 4 show SEM photomicrographs of slag spheres and sintered slag particles, respectively. Chemical analyses were obtained for several areas on the particles and on the neck

growth areas; average values are reported. The chemistry of slag spheres selected for microprobe analysis (Table 5) showed a rather wide variation in composition. Further, it was noted that the spheres appeared to be enriched in iron at the surface, apparently due to segregation of material as the molten slag spheres cooled. The segregation of iron was somewhat unexpected. The chemistry of sintered slag spheres (Table 6) showed the particles to be quite homogeneous, with no significant change in chemistry. The neck growth areas also show analysis consistent with the particle analysis. The points shown in Figure 4 correspond to the points in Table 6. 


\section{DRAFT}

TABLE 4

Chemistry of Glass Spheres and Illinois No. 6 Slag

\begin{tabular}{lcr}
\hline Oxide, wt & Glass & Slag \\
\hline $\mathrm{Na}_{2} \mathrm{O}$ & 14.75 & 1.00 \\
$\mathrm{MgO}$ & 2.78 & 0.89 \\
$\mathrm{Al}_{2} \mathrm{O}_{3}$ & 0.00 & 17.27 \\
$\mathrm{SiO}_{2}$ & 71.21 & 50.73 \\
$\mathrm{P}_{2} \mathrm{O}_{5}$ & 0.15 & 0.56 \\
$\mathrm{SO}_{3}$ & 0.32 & 1.07 \\
$\mathrm{~K}_{2} \mathrm{O}$ & 0.00 & 2.12 \\
$\mathrm{CaO}$ & 0.23 & 7.79 \\
$\mathrm{TiO}_{2}$ & 9.83 & 1.36 \\
$\mathrm{Fe}_{2} \mathrm{O}_{3}$ & 0.67 & 17.20 \\
\hline
\end{tabular}

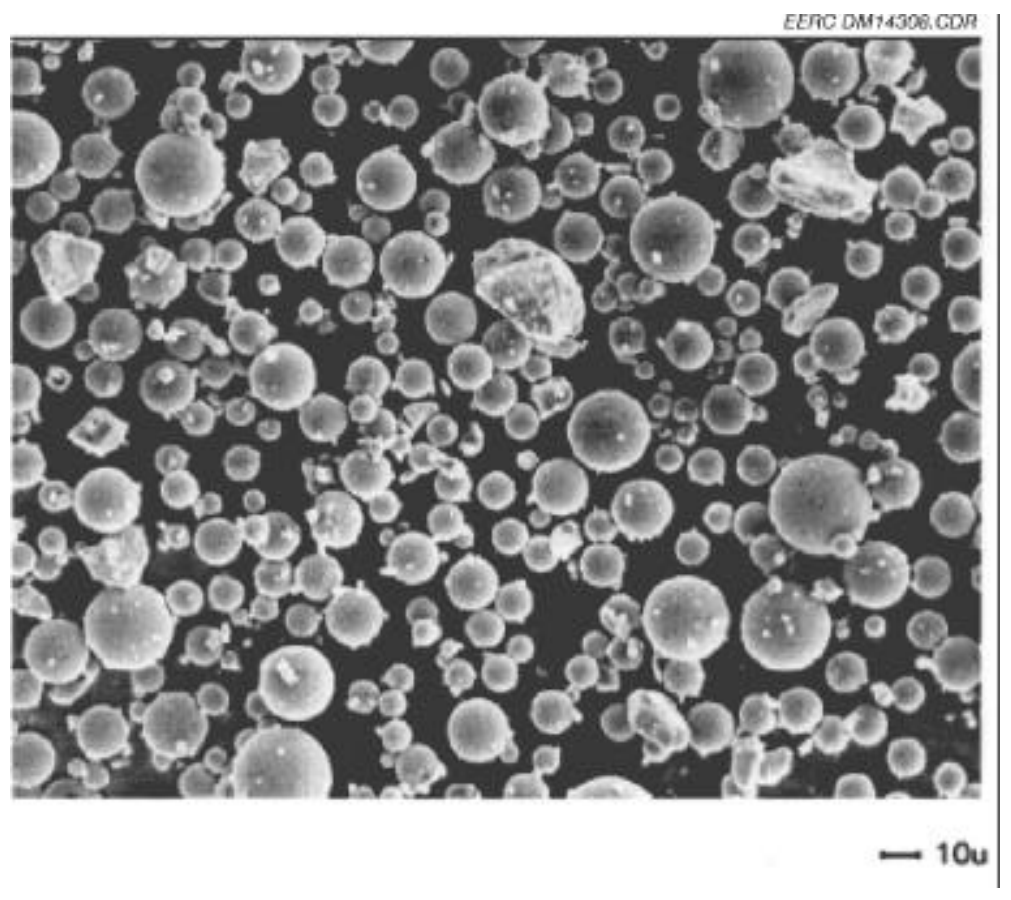

Figure 3. SEM photomicrograph of slag spheres. 

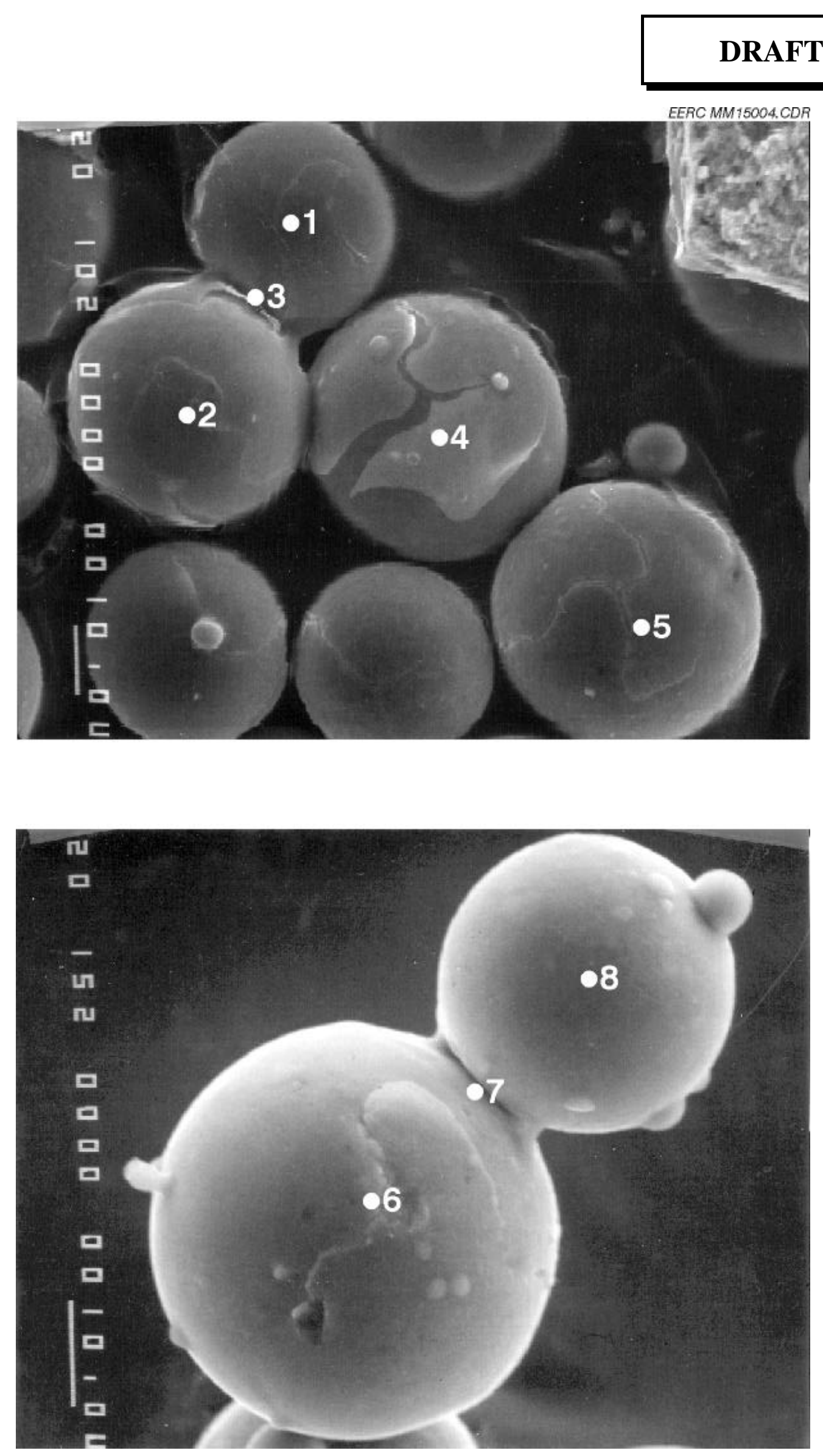

Figure 4. SEM photomicrograph of sintered slag spheres. 
TABLE 5

Analysis of Illinois No. 6 Slag Spheres

\begin{tabular}{|c|c|c|c|c|c|c|c|c|c|c|c|}
\hline \multirow[b]{2}{*}{ Particle } & \multirow[b]{2}{*}{ Size, $\mu \mathrm{m}$} & \multicolumn{10}{|c|}{ Element, wt\% } \\
\hline & & $\mathrm{Na}$ & $\mathrm{Si}$ & $\mathrm{Ca}$ & $\mathrm{Mg}$ & $\mathrm{Al}$ & $\mathrm{P}$ & $\mathrm{S}$ & $\mathrm{K}$ & $\mathrm{Ti}$ & $\mathrm{Fe}$ \\
\hline 1 & 25.0 & 1.71 & 47.06 & 9.72 & 1.23 & 18.03 & 0.13 & 0.19 & 3.22 & 1.05 & 17.66 \\
\hline 2 & 32.5 & 1.31 & 48.30 & 9.74 & 0.88 & 19.34 & 0.09 & 0.05 & 2.21 & 1.14 & 16.95 \\
\hline 3 & 12.5 & 0.37 & 28.66 & 10.03 & 0.99 & 11.85 & 1.30 & 2.49 & 4.95 & 3.32 & 36.04 \\
\hline 4 & 10.0 & 1.78 & 49.16 & 8.98 & 1.85 & 20.91 & 0.37 & 0.00 & 3.36 & 1.38 & 12.22 \\
\hline 5 & 27.5 & 0.54 & 40.74 & 12.28 & 0.67 & 15.45 & 0.20 & 0.00 & 3.06 & 2.45 & 24.61 \\
\hline 6 & 25.0 & 0.90 & 30.46 & 15.50 & 0.47 & 10.41 & 0.00 & 0.07 & 3.40 & 1.89 & 36.91 \\
\hline 8 & 30.0 & 1.00 & 47.89 & 12.20 & 1.08 & 17.88 & 0.25 & 0.23 & 2.92 & 0.91 & 15.65 \\
\hline 9 & 26.7 & 1.07 & 43.18 & 10.43 & 0.90 & 16.58 & 0.66 & 0.77 & 3.54 & 0.75 & 22.13 \\
\hline 10 & 26.7 & 1.61 & 40.06 & 8.97 & 0.95 & 16.25 & 0.12 & 0.00 & 3.34 & 1.29 & 27.42 \\
\hline 11 & 23.3 & 1.52 & 46.56 & 9.06 & 1.05 & 18.75 & 0.07 & 0.32 & 3.16 & 1.20 & 18.32 \\
\hline 12 & 13.3 & 1.27 & 40.54 & 7.02 & 0.67 & 15.11 & 1.06 & 7.31 & 2.13 & 2.04 & 22.87 \\
\hline 13 & 10.0 & 1.30 & 45.90 & 8.79 & 1.33 & 17.92 & 0.00 & 0.00 & 3.20 & 1.12 & 20.43 \\
\hline 15 & 15.2 & 1.98 & 49.54 & 9.25 & 1.13 & 19.06 & 0.92 & 0.00 & 3.23 & 1.25 & 13.63 \\
\hline 16 & 15.2 & 0.74 & 34.54 & 9.43 & 0.14 & 11.17 & 0.99 & 1.74 & 3.34 & 1.88 & 36.02 \\
\hline 17 & 30.3 & 1.25 & 45.77 & 9.65 & 0.71 & 18.38 & 0.62 & 0.24 & 3.24 & 1.67 & 18.46 \\
\hline 18 & 30.3 & 2.25 & 46.74 & 10.86 & 0.97 & 17.90 & 0.27 & 0.00 & 3.04 & 0.79 & 17.18 \\
\hline 19 & 9.1 & 1.69 & 50.45 & 9.78 & 1.44 & 18.71 & 0.73 & 0.00 & 3.10 & 1.43 & 12.67 \\
\hline 20 & 3.0 & 1.59 & 44.22 & 10.16 & 1.15 & 17.07 & 0.28 & 0.58 & 2.98 & 0.98 & 20.98 \\
\hline \multicolumn{2}{|c|}{ Average } & 1.33 & 43.32 & 10.10 & 0.98 & 16.71 & 0.45 & 0.78 & 3.19 & 1.47 & 21.67 \\
\hline \multicolumn{2}{|c|}{ Standard Deviation } & 0.50 & 6.42 & 1.81 & 0.38 & 2.93 & 0.41 & 1.77 & 0.57 & 0.65 & 7.83 \\
\hline
\end{tabular}




\section{DRAFT}

TABLE 6

Analysis of HSM-Sintered Illinois No. 6 Slag Spheres

\begin{tabular}{lcccccccccc}
\hline & \multicolumn{10}{c}{ Element, wt\% } \\
\cline { 2 - 11 } Point & $\mathrm{Na}$ & $\mathrm{Si}$ & $\mathrm{Ca}$ & $\mathrm{Mg}$ & $\mathrm{Al}$ & $\mathrm{P}$ & $\mathrm{S}$ & $\mathrm{K}$ & $\mathrm{Ti}$ & $\mathrm{Fe}$ \\
\hline 1 & 2.27 & 31.76 & 12.46 & 0.81 & 12.61 & 0.53 & 0.50 & 1.18 & 2.29 & 35.35 \\
2 & & & & & & & & & & \\
3 & 2.73 & 33.68 & 9.48 & 1.05 & 12.92 & 0.69 & 0.05 & 2.43 & 1.16 & 35.74 \\
4 & 2.51 & 38.28 & 9.40 & 1.24 & 13.78 & 0.00 & 0.10 & 2.89 & 1.27 & 29.57 \\
5 & 2.50 & 42.04 & 9.24 & 1.60 & 14.95 & 0.00 & 0.00 & 0.00 & 1.34 & 27.71 \\
6 & 2.89 & 36.28 & 14.14 & 0.00 & 16.60 & 0.00 & 0.00 & 0.00 & 1.95 & 27.23 \\
7 & 3.62 & 40.75 & 6.17 & 1.86 & 17.36 & 0.36 & 0.00 & 0.92 & 0.97 & 27.38 \\
8 & 1.72 & 36.10 & 7.99 & 1.06 & 15.96 & 0.09 & 0.18 & 2.83 & 1.25 & 32.64 \\
\hline
\end{tabular}

\subsubsection{HSM Growth Rate Measurements}

Particle radius and neck growth measurements were obtained by reviewing the videotaped sintering runs. The Illinois No. 6 slag spheres were more difficult to observe under HSM because of their dark color; therefore neck growth measurements were more difficult to obtain. The particle radius and neck growth measurements were used to calculate the degree of sintering $\mathrm{x} / \mathrm{r}$, where $\mathrm{x}$ is the radius of the sintering neck and $\mathrm{r}$ is the arithmetic average radius of the sintering particles.

Figure 5 shows $\mathrm{x} / \mathrm{r}$ plotted against time (sec) for the soda-lime spheres at three temperatures: $674^{\circ}, 684^{\circ}$, and $690^{\circ} \mathrm{C}$. Similarly, Figure 6 shows $\mathrm{x} / \mathrm{r}$ vs. time for the Illinois No. 6 slag spheres at $783^{\circ}, 810^{\circ}$, and $930^{\circ} \mathrm{C}$. The replicate plots at each temperature represent different pairs of sintered particles and give an indication of the repeatability of the data.

From the plots, it appears that the sintering should be done for a longer time to more definitively show the curvature of the plots. The test with the soda-lime glass at $690^{\circ} \mathrm{C}$ apparently was not continued long enough to observe the curvature seen at the other two temperatures. The downward curvature with the Illinois No. 6 slag at $810^{\circ} \mathrm{C}$ may be due to each of these particle pairs having a third particle attached to it, with one particle pair growing at the expense of the neck of the other particle pair.

\subsubsection{Viscosity Calculation with HSM Measurements}

The particle radius and neck growth measurement data were used to calculate dynamic viscosity using four analytical models: Frenkel (1) Frenkel-Eshelby (2), Hopper (2, 3) and Modified Frenkel (4). Frenkel's model, shown in Eq. 1, describes the rate of coalescence 

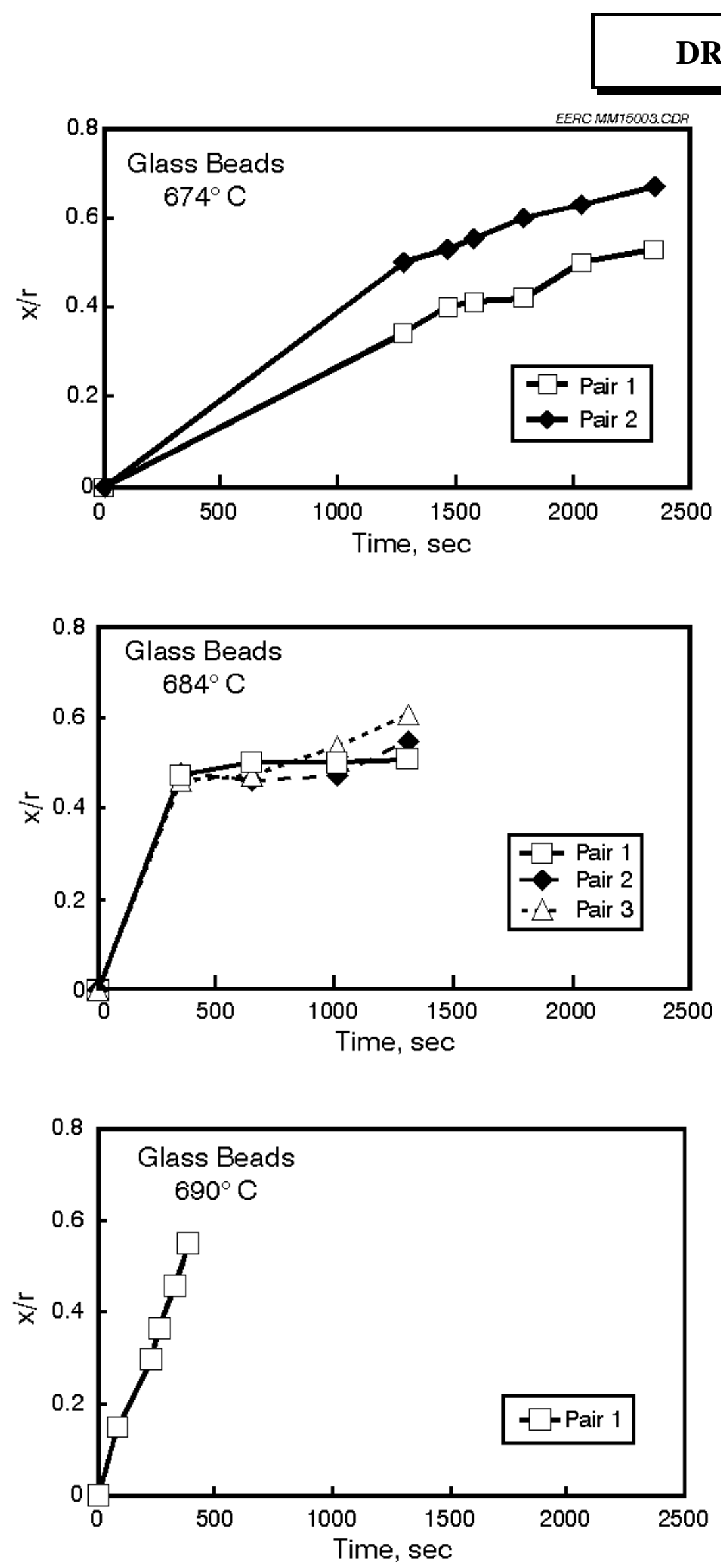

Figure 5. Plot of $\mathrm{x} / \mathrm{r}$ versus time for soda-lime spheres. 

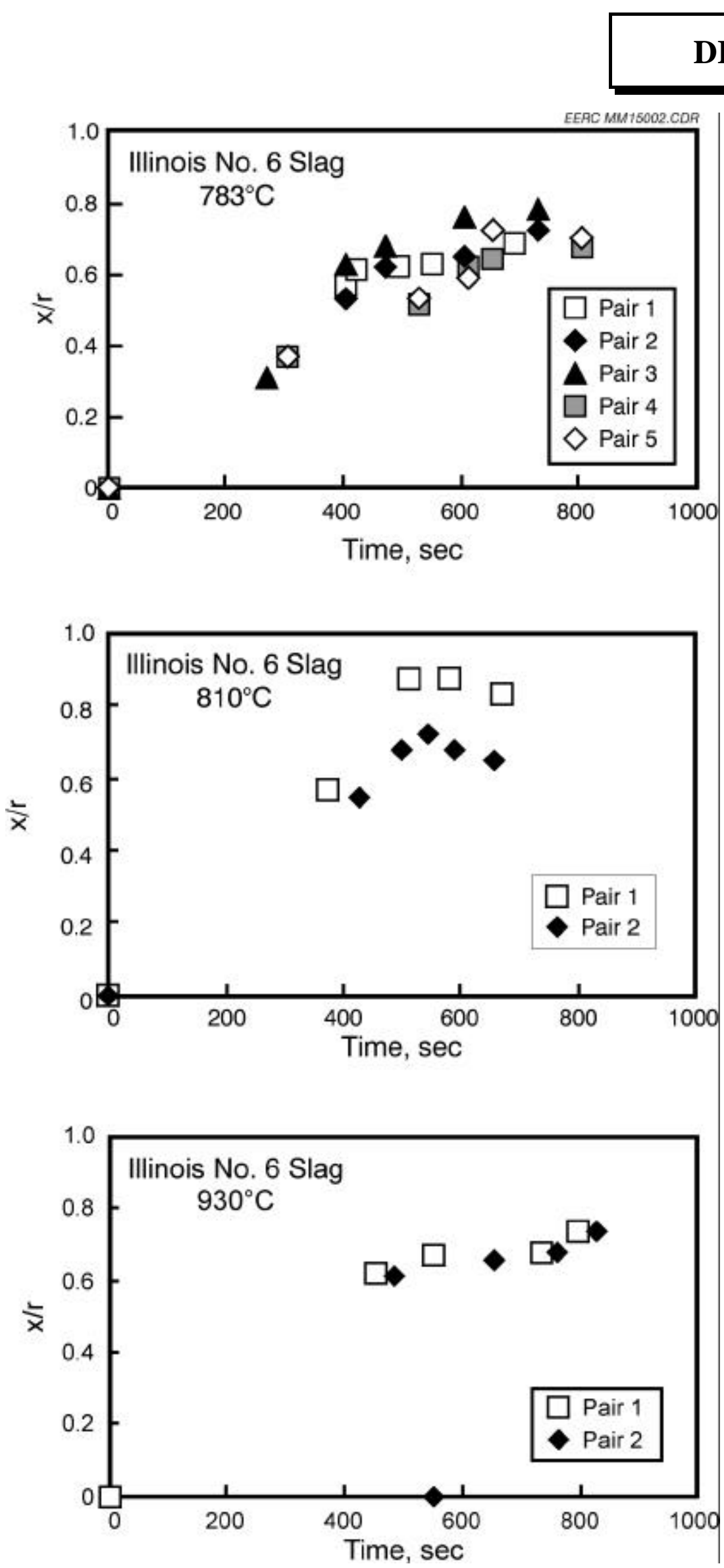

Figure 6. Plot of $\mathrm{x} / \mathrm{r}$ versus time for Illinois No. 6 slag spheres. 


\section{DRAFT}

occurring by Newtonian viscous flow under the action of surface tension for two identical spheres:

$$
\mathrm{x} / \mathrm{r}=[1.5(\gamma \mathrm{t}) /(\eta \mathrm{r})]^{1 / 2}
$$

where $\eta=$ viscosity $(\mathrm{Pa} \cdot \mathrm{sec})$.

$\mathrm{x}=$ radius $(\mathrm{m})$ of neck between two spherical particles.

$\mathrm{t}=$ time $(\mathrm{sec})$.

$\mathrm{r}=$ particle radius $(\mathrm{m})$ at time $\mathrm{t}$.

$\gamma=\operatorname{surface}$ tension $(\mathrm{N} / \mathrm{m})$.

Frenkel's model was corrected by Eshelby to satisfy the continuity equation for an incompressible fluid. The corrected model, referred to as the Frenkel-Eshelby model (Eq. 2), and the Frenkel model are both limited to Newtonian flow and only in the early stages of sintering when the particle diameters remain relatively constant, i.e., $\mathrm{x} / \mathrm{r}<0.3$.

$$
\mathrm{x} / \mathrm{r}=[(\gamma \mathrm{t}) /(\eta \mathrm{r})]^{1 / 2}
$$

Hopper's model for sintering is based on the exact analytical solution of the Navier-Stokes equation for two-dimensional viscous flow driven by capillary forces acting on the free surface. Hopper's analysis was applied to two long cylinders having an inverse ellipse as their cross section $(2,3)$. The Modified Frenkel model, as developed by Pokluda, Bellehumeur, and Vlachopoulos, is based on an approach similar to that used by Frenkel and Eshelby in their model derivations (4). However, in contrast to the Frenkel and Frenkel-Eshelby models, the Modified Frenkel model is applicable to all stages of spherical particle sintering. Further, the Modified Frenkel model considers the change in particle radius as sintering progresses.

Solutions of the Hopper and Modified Frenkel models, although not trivial, were not required for this test program. Values of dimensionless time $\left[(\gamma t) /\left(\eta r_{f}\right)\right]$ and the corresponding degree of sintering $\left(\mathrm{x} / \mathrm{r}_{\mathrm{f}}\right)$ have been computed by Hopper (3) and are presented in Table B-1, Appendix B. Similarly, values of $\left[(\gamma t) /\left(\eta r_{o}\right)\right]$ and $x / r$ have been computed by Pokluda, Bellehumeur, and Vlachopoulos (4) and are presented in Table B-2, Appendix B. The variable $r_{f}$ is the final particle radius for the Hopper model, and $r_{o}$ is the initial particle radius for the Modified Frenkel model.

For this study, a best-fit curve was generated from the tabulated values (dimensionless time, $\tau$, and degree of sintering, X) for both the Hopper and Modified Frenkel models. The general equations for the best-fit curves for the Hopper and Modified Frenkel models are shown in Eqs. 3 and 4 , respectively.

$$
\begin{aligned}
& \tau=\left[\left(a+c X+e X^{2}\right) /\left(1+b X+d X^{2}+f X^{3}\right)\right] \\
& \tau=\left[\left(a+c X^{2}+e X^{4}\right) /\left(1+b X^{2}+d X^{4}+f X^{6}\right)\right]
\end{aligned}
$$




\section{DRAFT}

The independent variable $\mathrm{X}$ is $\left(\mathrm{x} / \mathrm{r}_{\mathrm{f}}\right)$ for the Hopper model and $(\mathrm{x} / \mathrm{r})$ for the Modified Frenkel model. Similarly, the dependent variable $\tau$ is $\left[(\gamma t) /\left(\eta r_{f}\right)\right]$ for the Hopper model and $\left[(\gamma t) /\left(\eta r_{o}\right)\right]$ for the Modified Frenkel model. For the Hopper model, $r_{f}$ is $r_{o}(2)^{1 / 2}$. Coefficients $a, b, c, d$, e, and $f$ for both models are presented in Table 7.

\section{TABLE 7}

Coefficients for Hopper and Modified Frenkel Equations

\begin{tabular}{lrrrrrr}
\hline & \multicolumn{7}{c}{ Coefficient } \\
\cline { 2 - 7 } Model & $\mathrm{a}$ & $\mathrm{b}$ & $\mathrm{c}$ & $\mathrm{d}$ & $\mathrm{e}$ & $\mathrm{f}$ \\
\hline Hopper & -0.0136 & -1.3067 & 0.82496 & -0.1083 & -0.7982 & 0.4169 \\
$\begin{array}{r}\text { Modified } \\
\text { Frenkel }\end{array}$ & -0.0129 & -0.5603 & 1.32777 & -1.5526 & -1.3050 & 1.1140 \\
\hline
\end{tabular}

Dynamic viscosity values were calculated from each of the four models for each $\mathrm{x} / \mathrm{r}$ (and corresponding t) value. The Frenkel and Frenkel-Eshelby models, Eqs. 1 and 2, respectively, were rearranged to solve for the unknown variable, $\eta$. In applying the Hopper and Modified Frenkel models, Eqs. 3 and 4 were each used to compute dimensionless time values $(\tau)$ for each corresponding $\mathrm{x} / \mathrm{r}$ value. The dynamic viscosity was then calculated from Eq. 5 , where $r$ is $r_{f}$ from the Hopper model or $r_{o}$ from the Modified Frenkel model. The surface tension $(\gamma)$ value for the soda-lime glass, $0.304 \mathrm{~N} / \mathrm{m}$, was obtained from the literature (5). As an approximation, the same value was used as the surface tension for the Illinois No. 6 slag.

$$
\eta=(\gamma \mathrm{t}) /(\tau \mathrm{r})
$$

The dynamic viscosity values computed from the four models are presented in Table 8 for the soda-lime glass and Illinois No. 6 slag spheres. The value presented for each pair of sintered particles is an arithmetic average of the dynamic viscosities calculated at each measured $\mathrm{x} / \mathrm{r}$ (and t). Owing to the small number of observations for each pair of sintered particles, no data points were excluded from the averaging. Viscosities were also estimated for the soda-lime glass and Illinois No. 6 slag using the VISCALC (6) thermodynamic equilibrium program; an Urbain equation, with parameters taken from the literature (6), was used to estimate viscosity for the soda-lime glass. Viscosity values predicted with VISCALC and the Urbain equation are also shown in Table 8.

The $\log _{10}(\eta / T)$ vs. $1 /$ T is plotted for the soda lime glass and Illinois No. 6 slag in Figures 7 and 8 , respectively. The viscosity $(\eta)$ is in poise and temperature $(T)$ is $K$. 


\section{DRAFT}

\section{TABLE 8}

Model Calculations of Soda-Lime Glass and Illinois No. 6 Slag Viscosities

\begin{tabular}{|c|c|c|c|c|c|c|c|c|c|}
\hline \multicolumn{10}{|c|}{ Viscosity (poise) $\times 10^{-8}$ Model } \\
\hline \multirow[b]{2}{*}{ Material } & \multirow[b]{2}{*}{ Temp. ${ }^{\circ} \mathrm{C}$} & \multirow[b]{2}{*}{ Pair } & \multicolumn{2}{|c|}{ Particle } & \multirow{2}{*}{$\begin{array}{l}\text { Frenkel- } \\
\text { Eshelby }\end{array}$} & \multirow{2}{*}{$\begin{array}{c}\text { Modified } \\
\text { Frenkel }\end{array}$} & \multirow[b]{2}{*}{ Hopper } & \multirow[b]{2}{*}{ VISCALC } & \multirow[b]{2}{*}{ Urbain } \\
\hline & & & Size, $\mu \mathrm{m}$ & Frenkel & & & & & \\
\hline \multirow[t]{6}{*}{ Glass } & 674 & 1 & 42,46 & 19.6 & 13.1 & 11.9 & 6.24 & 0.0080 & 6.31 \\
\hline & & 2 & 52,47 & 9.42 & 6.29 & 5.22 & 3.72 & & \\
\hline & 684 & 1 & 42,52 & 6.44 & 4.29 & 3.76 & 2.31 & 0.0062 & 3.63 \\
\hline & & 2 & 42,39 & 7.57 & 5.05 & 4.42 & 2.70 & & \\
\hline & & 3 & 41,40 & 6.51 & 4.34 & 3.72 & 2.43 & & \\
\hline & 690 & 1 & 22,19 & 9.47 & 6.31 & 5.95 & 2.38 & 0.0048 & 2.63 \\
\hline \multirow[t]{9}{*}{ Slag } & 783 & 1 & 22,24 & 5.17 & 3.28 & 2.65 & 2.13 & 0.047 & \\
\hline & & 2 & 18,16 & 7.39 & 4.92 & 3.85 & 3.04 & & \\
\hline & & 3 & 16,16 & 6.13 & 4.08 & 2.85 & 2.69 & & \\
\hline & & 4 & 24,22 & 7.27 & 4.85 & 4.01 & 2.74 & & \\
\hline & & 5 & 22,26 & 6.71 & 4.48 & 3.65 & 2.54 & & \\
\hline & 810 & 1 & 17,13 & 5.38 & 3.59 & 2.25 & 2.38 & 0.013 & \\
\hline & & 2 & 17,20 & 6.29 & 4.19 & 3.20 & 2.64 & & \\
\hline & 930 & 1 & 40,39 & 3.14 & 2.09 & 1.56 & 1.35 & 0.0022 & \\
\hline & & 2 & 36,44 & 3.42 & 2.28 & 1.68 & 1.47 & & \\
\hline
\end{tabular}

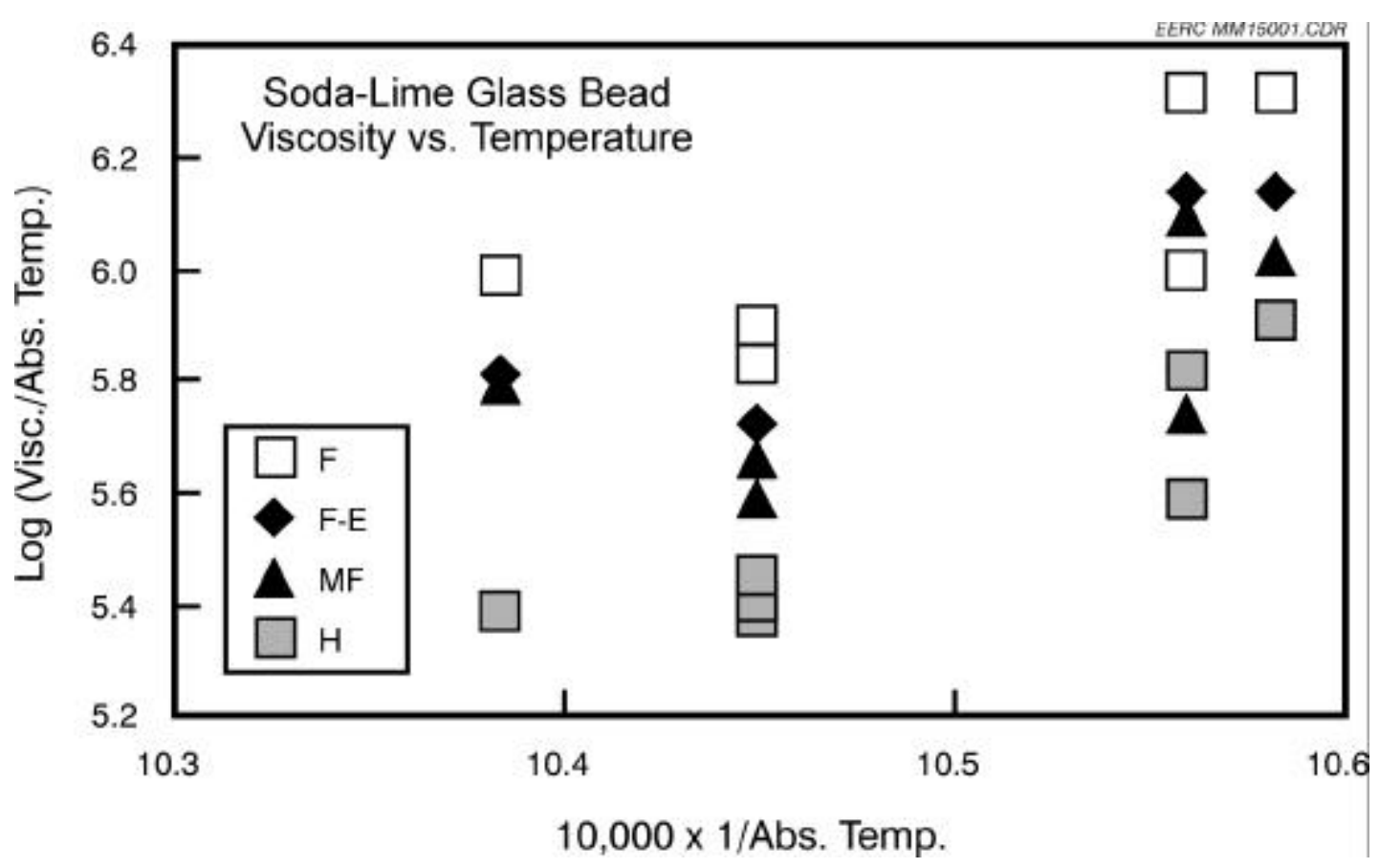

Figure 7. Plot of $\log _{10}(\eta / T)$ versus $1 / T$ for the soda-lime glass. 


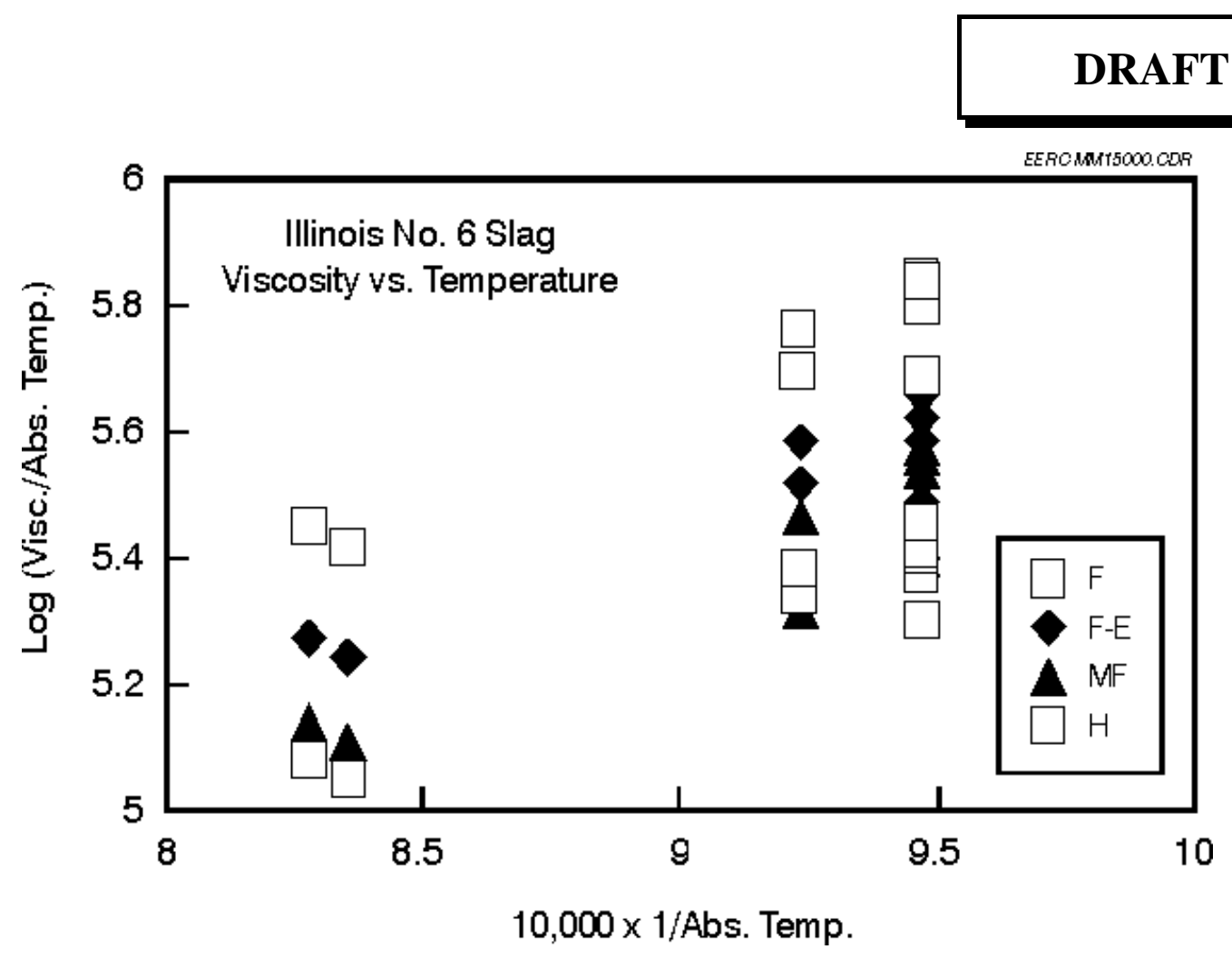

Figure 8. Plot of $\log _{10}(\eta / T)$ versus $1 /$ T for the Illinois No. 6 slag.

\subsubsection{Discussion}

Preliminary tests indicate that HSM may be a very useful tool to obtain sintering measurements of coal ash or boiler deposits under controlled conditions to allow predictions of low-temperature viscosities. Selection of an appropriate sintering model, however, may be contingent on corroboration with other low-temperature viscosity data, e.g., values generated from stress-strain measurements. Although the sintering tests were not allowed to progress for a sufficient time, it is presumed that truly homogeneous particles would closely follow the rate of sintering predicted by the Modified Frenkel model if particle mass and density were maintained and phase separation or reaction did not occur.

The limited data indicate that all four analytical sintering models predicted viscosities within the range of interest for low-temperature fouling $\left(10^{5}\right.$ to $10^{8}$ poise). Further, at any given sintering temperature, all four models predicted viscosities within one order of magnitude. The reproducibility of viscosity predictions at any given temperature was quite good for the Illinois No. 6 slag. The model predictions also correctly exhibited a decrease in viscosity with an increase in sintering temperature.

Viscosities predicted by the Frenkel-Eshelby and Modified Frenkel models differ by less than $20 \%$ for the soda-lime glass. Most of the viscosities were calculated at $\mathrm{x} / \mathrm{r}$ values below 0.6. At values of $\mathrm{x} / \mathrm{r}$ above 0.6 , where most viscosities were calculated for the Illinois No. 6 slag, the Frenkel-Eshelby and Modified Frenkel model predictions show much greater divergence. Because 


\section{DRAFT}

the Modified Frenkel model becomes asymptotic with the Frenkel-Eshelby model as $\mathrm{x} / \mathrm{r}$ approaches 0 , predictions with these two models are similar at low $\mathrm{x} / \mathrm{r}$.

Predictions of viscosities for the soda-lime glass using the Urbain equation were of the same order of magnitude as predictions generated by the sintering models. However, no one sintering model tended to closely parallel the Urbain predictions throughout the range of sintering temperatures. The VISCALC thermodynamic equilibrium program predicted viscosities of two to three orders of magnitude lower than values predicted by the sintering models or the Urbain equation.

\subsubsection{Conclusions}

Preliminary tests indicate that HSM may be a very useful tool to obtain sintering measurements of coal ash or boiler deposits under controlled conditions. Viscosity measurement in low-temperature ranges such as below $900^{\circ} \mathrm{C}$-where deposit formation is particularly of interest in gasification systems - is possible using this technique. The technique also promotes a better morphological understanding of how sintering occurs at these low temperatures. Selection of an appropriate sintering model, however, may be contingent on corroboration with other lowtemperature viscosity date, e.g., values generated from stress-strain measurements.

At any given sintering temperature, all four models will predict viscosities within one order of magnitude. It is not possible, without further corroborating viscosity measurements, to select a model that most closely predicts the sintering behavior of coal slag or ashes.

\subsection{Task 3 - Ash Deposit Chemistry and Phase Relationships}

\subsubsection{Task 3 Objectives}

Although it is well established that sulfides readily break down in combustion environments, usually into oxides of iron (7), the mechanisms of sulfide formation in gasification are not well understood. Work by Benson and Sondreal (8) revealed that initial sulfidation of coal ash or bed material may have led to $\mathrm{Ca}-\mathrm{Mg}$-rich aluminosilicate deposits that formed in a pressurized circulating fluidized-bed gasifier. Volatile sulfide species can exist in the temperatures noted for the gasifier studied by Benson and Sondreal (8) and also in other gasification environments. Lowmelting-point sulfides of $\mathrm{Ca}, \mathrm{Fe}$, or possibly even $\mathrm{Na}$ are stable at temperatures of less than $900^{\circ} \mathrm{C}$ in these environments, but the specific interaction that causes the sulfides to lead to other silicate and oxide components becoming the "glue" material in a deposit is not understood.

For alloy corrosion studies in this task, there are several questions relating to the specific impacts of gas and ash composition, alloy type, and temperature on the magnitude and rate of corrosion of alloys that are being used in the construction of high-temperature components of advanced supercritical boilers. Ultrasupercritical (USC) boilers employing higher temperatures and pressures than conventional coal-fired boilers require improved materials to achieve high performance and long life. These energy systems will be required to fire low-grade solid fuels and meet higher energy conversion efficiencies. The steam cycle used in a typical conventional power 


\section{DRAFT}

system is limited to a maximum pressure of 175 bar and a metal temperature of $550{ }^{\circ} \mathrm{C}$, with efficiencies around $35 \%$. To boost the efficiency significantly, up to 50\%, working pressures and temperatures of $325 \mathrm{bar} / 625^{\circ} \mathrm{C}$ are required, exposing the metal system components to a much more corrosive environment.

Japanese researchers are already utilizing USC parameters in two liquefied natural gas (LNG)-fired units at Kawagoe, which have been operating extremely well since being commissioned in 1989 and 1990. Danish workers are also in the process of building two USC units (CONVOY), along with three contractors working on low-emission boiler systems (LEBS) for DOE. This illustrates how utilities are being pushed toward lower emissions and higher efficiencies.

A few key components to consider in a USC system are the thick-walled sections of the boiler, steam tubes, and superheaters. The main properties required of an alloy for these systems are resistance to ash corrosion and creep rupture strength. Of these two properties, little information on the corrosion resistance of these alloys is currently available. Knowledge of the expected integrity of various alloys over time is crucial to the success of supercritical boilers.

Several questions need to be answered in this task relating to ash deposits in advanced power systems, including the following:

- How does the formation of sulfide species in a gasification system impact the formation of deposits?

- What are some of the mechanisms of fine particulate agglomeration and deposition in gasifiers?

- How does ash composition, flue gas composition, and the composition of various alloys impact corrosion severity and rates of corrosion for alloy materials of the type used in high-efficiency supercritical boilers?

\subsubsection{Task 3 Results - Deposit Ash Chemistry and Phase Relationships}

This program obtained deposit samples from the TRDU which is a $200-300-\mathrm{lb} / \mathrm{hr}$ pressurized circulating fluid-bed gasifier similar to the gasifier being tested at the Wilsonville facility. The TRDU has an operating gas temperature of up to $1093^{\circ} \mathrm{C}$, a gas flow rate of $350 \mathrm{scfm}$, and an operating pressure of $120 \mathrm{psig}$. The TRDU system can be divided into three sections: the coal feed section, the TRDU, and the product recovery section. The TRDU proper, as shown in Figure 9, consists of a riser reactor with an expanded mixing zone at the bottom, a disengager, and a primary cyclone and standpipe. The standpipe is connected to the mixing section of the riser by a J-leg transfer line. All of the components in the system are refractory-lined and designed mechanically for $150 \mathrm{psig}$ and an internal temperature of $1093^{\circ} \mathrm{C}$. 


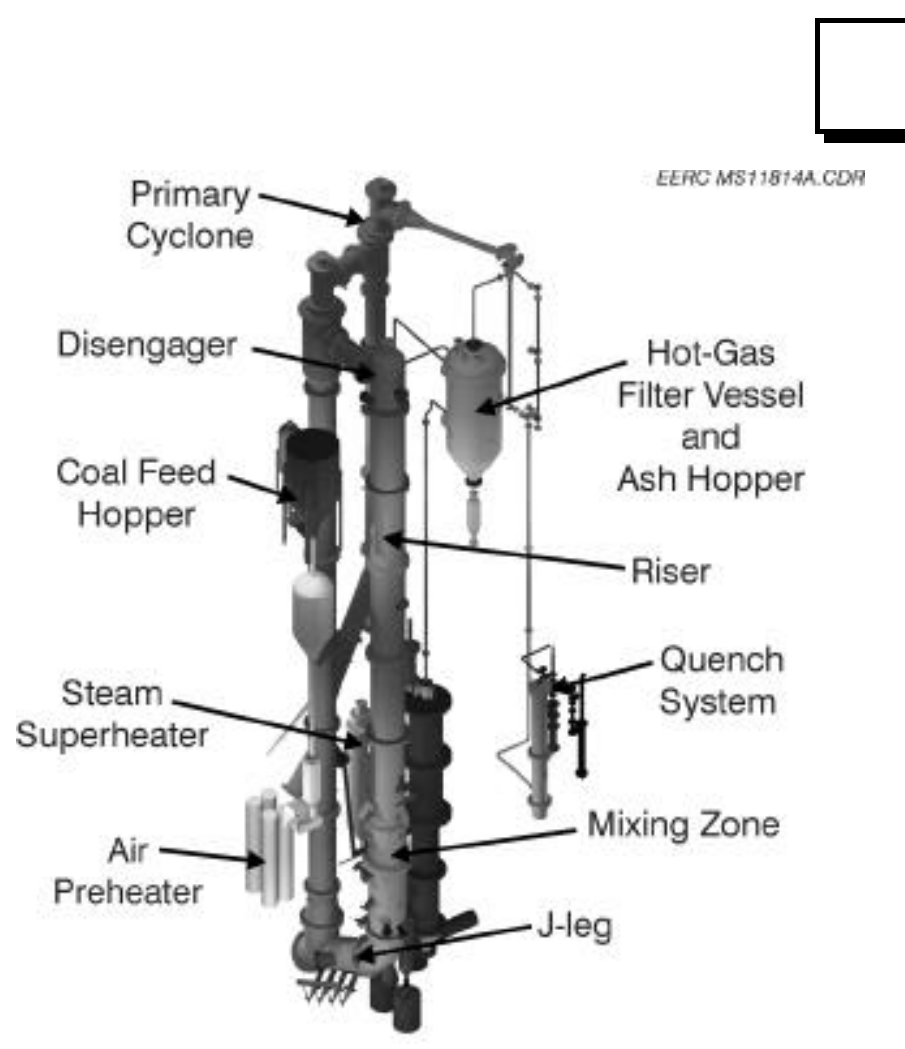

Figure 9. Schematic of the TRDU.

The premixed coal and limestone feed to the transport reactor can be admitted through three nozzles, which are at varying elevations. Two of these nozzles are located near the top of the mixing zone (gasification), and the remaining one is near the bottom of the mixing zone (combustion). During operation of the TRDU, feed is admitted through only one nozzle at a time. The coal feed is measured by an rpm controlled metering auger. Oxidant is fed to the reactor through two pairs of nozzles at varying elevations within the mixing zone. For the combustion mode of operation, additional nozzles are provided in the riser for feeding secondary air. Hot solids from the standpipe are circulated into the mixing zone, where they come into contact with the nitrogen and the steam being injected into the J-leg. This feature enables spent char to contact steam prior to the fresh coal feed. This staged gasification process is expected to enhance the process efficiency. Gasification or combustion and desulfurization reactions are carried out in the riser as coal, sorbent, and oxidant (with steam for gasification) flow up the tube. The solids circulation into the mixing zone is controlled by the solids level in the standpipe.

The riser, disengager, standpipe, and cyclones are equipped with several internal and skin thermocouples. Nitrogen-purged pressure taps are also provided to record differential pressure across the riser, disengager, and the cyclones. The data acquisition and control system scans the

data points every one-half second but is only saving the process data every 30 seconds. The bulk of entrained solids leaving the riser is separated from the gas stream in the disengager and circulated back to the riser via the standpipe. A solids stream is withdrawn from the standpipe via an auger to maintain the system's solids inventory. Gas exiting the disengager enters a primary cyclone that has been modified to provide variable particulate collection performance. Solids from the primary cyclone are collected in a lock hopper. Gas exiting this cyclone enters a jacketed-pipe 


\section{DRAFT}

heat exchanger before entering the hot-gas filter vessel (HGFV). The cleaned gases leaving the HGFV enter a quench system before being depressurized and vented to a flare.

The quench system uses a sieve tower and two direct-contact water scrubbers to act as heat sinks and remove impurities. All water and organic vapors are condensed in the first scrubber, with the second scrubber capturing entrained material and serving as a backup. The condensed liquid is separated from the gas stream in a cyclone that also serves as a reservoir. Liquid is pumped either to a shell-and-tube heat exchanger for reinjection into the scrubber or down to the product receiver barrels.

\subsubsection{TRDU Fuel Analysis}

The fuels which have been tested in the TRDU to date have consisted of a PRB subbituminous coal from the Wyodak seam at the Belle Ayr mine in Gillette, Wyoming, an Illinois No. 6 bituminous coal from Seam 6 of the Baldwin mine in Baldwin, Illinois, a western bituminous coal mined from the Hiawatha seam at the SUFCo mine in Salina, Utah, and a petroleum coke from the Hunt Oil Refinery in Tuscaloosa, Alabama. Table 9 shows the proximate, ultimate and XRF analysis of all the fuels. All fuels were mixed with Plum Run dolomite from the Greenfield formation before testing in the TRDU. The dolomite was mixed with the respective coals to provide a $\mathrm{Ca} / \mathrm{S}$ ratio of approximately 2 on a sorbent-only basis for the fuels being gasified ( $\sim 5 \mathrm{wt} \%$ for the PRB and SUFCo coals, and $17 \mathrm{wt} \%$ for the Illinois No. 6 coal) and at a $\mathrm{Ca} / \mathrm{S}$ ratio of $1.0(\sim 20 \mathrm{wt} \%)$ for the petroleum coke combustion test.

Table 10 summarizes the major minerals identified by CCSEM analyses of the PRB coal as a function of mineral particle diameter. This analysis shows that the mineral sizes are small $(70.5 \mathrm{wt} \%<10 \mu \mathrm{m})$. In addition, the difference between the ash concentration as identified as minerals and the total ash content of the coal suggests that approximately $25 \mathrm{wt} \%$ of the ash is organically associated (mostly calcium).

\subsubsection{TRDU Operation}

A test campaign was conducted during the weeks of February 19 and 28, 1997. During these weeks, approximately 204 hours of coal feed and 198 hours of gasification with the Wyodak fuel (over 190 hours of continuous operation) were achieved, with the system gases and fly ash passing through the filter vessel during the whole test campaign except during off-line cleaning experiments performed during the later stages of the test campaign. The TRDU gasification system performed well, and the desired 200 hours were achieved.

The TRDU was operated at a higher average temperature of $875^{\circ} \mathrm{C}$ since no deposition problems were seen in the riser and disengager as reported in previous tests. The last day, the gasifier temperature was decreased to $825^{\circ} \mathrm{C}$ to see if standpipe carbon levels could be increased. Table 11 summarizes the operational performance for the TRDU during the 200-hour test period. Coal feed rates ranged from 266 to $390 \mathrm{lb} / \mathrm{hr}$, and the gasifier pressure averaged $120 \mathrm{psig}$. The dry product gas produced ranged from $3.9 \%$ to $6.4 \% \mathrm{CO}, 6.3 \%$ to $9.6 \% \mathrm{H}_{2}, 7.6 \%$ to $11.0 \% \mathrm{CO}_{2}$, $0.2 \%$ to $1.5 \% \mathrm{CH}_{4}$, with the balance being $\mathrm{N}_{2}$ and other trace constituents. The moisture in the 
TABLE 9

Illinois No. 6, Wyodak, and SUFCo Coals, Tuscaloosa Petcoke, and Plum Run Dolomite Analyses

\begin{tabular}{|c|c|c|c|c|c|}
\hline & $\begin{array}{c}\text { - 10-mesh Wyodak } \\
\text { Subbituminous } \\
\text { Coal }\end{array}$ & $\begin{array}{c}\text {-10-mesh } \\
\text { Illinois No. } 6 \\
\text { Bituminous Coal } \\
\end{array}$ & $\begin{array}{c}-10 \text {-mesh } \\
\text { SUFCo Bituminous } \\
\text { Coal } \\
\end{array}$ & $\begin{array}{c}\text {-10-mesh } \\
\text { Tuscaloosa } \\
\text { Petroleum Coke }\end{array}$ & $\begin{array}{l}-35 \text {-mesh } \\
\text { Plum Run } \\
\text { Dolomite }\end{array}$ \\
\hline \multicolumn{6}{|c|}{ Proximate Analysis, as run, wt $\%$} \\
\hline Moisture & 20.0 & 8.5 & 9.5 & 0.9 & $\mathrm{NA}^{1}$ \\
\hline Volatile Matter & 38.9 & 36.0 & 39.1 & 9.6 & \\
\hline Fixed Carbon & 36.4 & 44.8 & 43.8 & 88.5 & \\
\hline Ash & 4.7 & 10.7 & 7.6 & 1.0 & \\
\hline \multicolumn{6}{|c|}{ Ultimate Analysis, $\mathrm{MF}^{2}$, wt $\%$} \\
\hline Carbon & 69.06 & 69.27 & 77.10 & 90.65 & NA \\
\hline Hydrogen & 5.19 & 5.03 & 4.61 & 3.89 & \\
\hline Nitrogen & 0.84 & 1.1 & 1.29 & 1.70 & \\
\hline Sulfur & 0.44 & 3.55 & 0.36 & 5.49 & \\
\hline Oxygen & 18.63 & 9.34 & 8.29 & 0.0 & \\
\hline Ash & 5.85 & 11.7 & 8.4 & 1.0 & \\
\hline \multicolumn{6}{|c|}{ Ash Composition, $\%$ as oxides } \\
\hline Calcium, $\mathrm{CaO}$ & 26.6 & 3.2 & 16.3 & 11.9 & 66.6 \\
\hline Magnesium, $\mathrm{MgO}$ & 7.0 & 1.6 & 3.0 & 5.1 & 27.5 \\
\hline Sodium, $\mathrm{Na}_{2} \mathrm{O}$ & 1.3 & 1.1 & 4.6 & 1.0 & 0.3 \\
\hline Silica, $\mathrm{SiO}_{2}$ & 27.8 & 53.9 & 38.3 & 18.9 & 2.7 \\
\hline Aluminum, $\mathrm{Al}_{2} \mathrm{O}_{3}$ & 13.1 & 21.2 & 9.3 & 4.8 & 1.0 \\
\hline Ferric, $\mathrm{Fe}_{2} \mathrm{O}_{3}$ & 5.5 & 13.6 & 6.1 & 7.6 & 1.3 \\
\hline Titanium, $\mathrm{TiO}_{2}$ & 1.3 & 0.9 & 0.8 & 0.0 & 0.0 \\
\hline Phosphorus, $\mathrm{P}_{2} \mathrm{O}_{5}$ & 1.0 & 0.2 & 0.2 & 0.1 & 0.0 \\
\hline Potassium, $\mathrm{K}_{2} \mathrm{O}$ & 0.3 & 1.9 & 0.2 & 0.7 & 0.3 \\
\hline Sulfur, $\mathrm{SO}_{3}$ & 16.0 & 2.5 & 21.1 & 13.8 & 0.4 \\
\hline Vanadium, $\mathrm{V}_{2} \mathrm{O}_{5}$ & $\mathrm{ND}^{3}$ & ND & ND & 30.2 & ND \\
\hline Nickel, NiO & ND & ND & ND & 6.0 & ND \\
\hline \multicolumn{6}{|l|}{ High Heating Value } \\
\hline Moisture-Free, Btu/lb & 11,700 & 12,080 & 12,200 & 15,300 & NA \\
\hline As-Received, Btu/lb & 9,750 & 11,300 & 11,040 & 15,150 & NA \\
\hline Loss on Ignition, as run & NA & NA & NA & NA & 43.1 \\
\hline \multicolumn{6}{|l|}{$\begin{array}{l}1 \text { Not applicable. } \\
{ }^{2} \text { Moisture-free. } \\
{ }^{3} \text { Not determined. }\end{array}$} \\
\hline
\end{tabular}


TABLE 10

Summary of CCSEM Results for Belle Ayr (Wyodak) Subbituminous Coal, wt $\%$ on a mineral basis

\begin{tabular}{lrrrrrrr}
\hline & & & & & & & \\
Particle-Size Dist., $\mu \mathrm{m}$ & $1.0-3.2$ & $3.2-10.0$ & $10.0-31.6$ & $31.6-100.0$ & $100-316$ & $>316$ & Total \\
\hline Quartz & 5.2 & 9.1 & 6.3 & 2.4 & 0.2 & 0.0 & 23.2 \\
Rutile & 0.1 & 0.3 & 0.1 & 0.0 & 0.0 & 0.0 & 0.5 \\
Calcite & 0.2 & 0.1 & 0.0 & 0.0 & 0.0 & 0.0 & 0.3 \\
Kaolinite & 3.0 & 14.0 & 4.8 & 4.2 & 1.7 & 1.8 & 29.5 \\
Montmorillonite & 2.0 & 8.9 & 1.3 & 0.0 & 0.4 & 0.0 & 12.7 \\
K Al-Silicate & 0.1 & 0.2 & 0.0 & 0.0 & 0.2 & 0.0 & 0.5 \\
Ca Al-Silicate & 0.4 & 0.1 & 0.0 & 0.0 & 0.0 & 0.0 & 0.5 \\
Aluminosilicate & 0.8 & 2.4 & 1.0 & 0.2 & 0.0 & 0.0 & 4.4 \\
Mixed Al-Silica & 0.1 & 0.1 & 0.1 & 0.0 & 0.0 & 0.0 & 0.3 \\
Pyrite & 0.2 & 0.4 & 1.5 & 0.0 & 0.0 & 0.0 & 2.1 \\
Gypsum & 0.0 & 0.1 & 0.0 & 0.0 & 0.0 & 0.0 & 0.1 \\
Barite & 0.2 & 0.8 & 0.0 & 0.0 & 0.0 & 0.0 & 1.0 \\
Ca Al-P & 5.0 & 3.5 & 1.6 & 0.0 & 0.0 & 0.0 & 10.1 \\
Gypsum-Barite & 0.1 & 0.1 & 0.0 & 0.0 & 0.0 & 0.0 & 0.2 \\
Gyp-Al-Silicate & 0.1 & 0.0 & 0.0 & 0.0 & 0.0 & 0.0 & 0.1 \\
Si-Rich & 0.5 & 4.4 & 0.3 & 0.2 & 0.0 & 0.0 & 5.4 \\
Ca-Rich & 0.2 & 0.1 & 0.0 & 0.0 & 0.0 & 0.0 & 0.3 \\
Unknown & 3.0 & 4.9 & 0.8 & 0.2 & 0.0 & 0.0 & 8.8 \\
Total & 21.1 & 49.4 & 17.8 & 7.3 & 2.5 & 1.8 & 100.0 \\
\hline
\end{tabular}

TABLE 11

TRDU Actual Operating Conditions

\begin{tabular}{lc}
\hline Parameter & P051 \\
\hline Conditions & Gasification \\
Coal & Wyodak \\
Moisture Content, \% & 23.3 \\
Pressure, bar & 9.3 \\
Steam:Coal Ratio & 0.30 \\
Air:Coal Ratio & 2.5 \\
Ca:S Ratio, mole, total & 4.7 \\
Coal Feed Rate, lb/hr & $280-390$ \\
Mixing Zone, ${ }^{\circ} \mathrm{C}$, avg. & 878 \\
Riser, ${ }^{\circ} \mathrm{C}$, avg. & 856 \\
Standpipe, ${ }^{\circ} \mathrm{C}$, avg. & 760 \\
Conversion, \% (excluding dipleg) & $92(98)$ \\
Carbon in Bed, \%, Standpipe (dipleg) & 6 to $15(15$ to 35$)$ \\
Riser Velocity, ft/sec & 32 to 38 \\
Standpipe Velocity, ft/sec & 0.15 to 0.27 \\
Circulation Rate, lb/hr & 2600 to 4400 \\
Duration, hr & 204 \\
Time & $15: 45-18: 45$ \\
Date & $2-20$ to $2-28$ \\
\hline
\end{tabular}




\section{DRAFT}

fuel gas averaged $15 \%$. The $\mathrm{H}_{2} \mathrm{~S}$ concentration started at approximately $500 \mathrm{ppm}$ and increased to approximately $1200 \mathrm{ppm}$ when recycling of dipleg material was terminated. Calculated recirculation rates started at approximately $4500 \mathrm{lb} / \mathrm{hr}$ and slowly decreased to approximately $2500 \mathrm{lb} / \mathrm{hr}$ until the standpipe fluffing nitrogen was turned up at the end of the test where it increased back to $4200 \mathrm{lb} / \mathrm{hr}$. Relative bed density dropped from $98 \%$ for a $100 \%$ silica sand bed to approximately $62 \%$ with the high-carbon and coal ash bed.

Four test campaigns have been conducted during the past year. During these tests, 179 hours of gasification and 234 hours of coal feed with Wyodak subbituminous coal and 41 hours of gasification on Illinios No. 6 bituminous coal and 118 hours of gasification on SUFCo bituminous coal were completed. In addition, 70 hours of combustion on a petroleum coke were also completed, with the system gases and fly ash passing through the filter vessel during all of the test campaigns. The TRDU was operated at an average temperature of $875^{\circ} \mathrm{C}$ for the Wyodak coal tests and up to $950^{\circ} \mathrm{C}$ for the bituminous coal tests. Coal feed rates ranged from 220 up to $320 \mathrm{lb} / \mathrm{hr}$, depending on the coal type and operating conditions, while the gasifier pressure averaged $120-11 \% \mathrm{CO}_{2}$, and $1.0 \%-2.5 \% \mathrm{CH}_{4}$, with the balance being $\mathrm{N}_{2}$ and other trace constituents. The $\mathrm{H}_{2} \mathrm{~S}$ concentration averaged 50 to $400 \mathrm{ppm}$. Correction of the fuel gas concentrations for nitrogen purges and the high system heat loss as a percentage of the coal feed demonstrates that heating values ranging from 105 to $130 \mathrm{Btu} / \mathrm{scf}$ can be achieved. Table 12 summarizes the operating conditions for these tests.

Factors that affect the TRDU product gas quality appear to be circulation rate, coal type, temperature, and air:coal and steam:coal ratios. A decrease in circulation rate improves the product gas quality by increasing the solid residence time in the gasification zones of the TRDU; however, lower circulation rate tests are more prone to deposition and agglomeration problems as a result of inadequate gas-solid mixing in the mixing zone. The less reactive bituminous fuels were gasified at higher temperatures to produce a product gas quality similar to those obtained with the Wyodak fuel. Higher operating temperatures increase carbon conversion for the TRDU, but again at the risk of increased ash deposition. Higher steam/coal ratios result in improved product gas quality with increased hydrogen and carbon dioxide formation from the water-gas shift reaction, but data also show additional $\mathrm{CO}$ was produced via the steam-carbon reaction. Higher air/coal ratios gave lower product gas quality, especially at ratios above 3.5, with generally under 3.0 providing the best product gas.

\subsubsection{HGFV Operation}

Operation of the HGFV during the last year has tested 1-meter-long candles from 3M (SiCcoated fiber), Schumacher Dia-Schumalith 10-20, and Pall Advanced Separations Vitropore 326 and iron aluminide candles along with Westinghouse fail-safes. There have been no candles failures of these candles in $~ 700$ hours of testing. The HGFV has been operated between $510^{\circ}$ to $570^{\circ} \mathrm{C}$ at a face velocity of approximately 3.8 to $4.5 \mathrm{ft} / \mathrm{min}$. Backpulse operating parameters were 270 to 400 psig reservoir pressure with a 1/2-second opening time. The average particulate loading going into the HGFV has ranged from approximately $4500 \mathrm{ppm}$ up to 38,000 ppm with a $\mathrm{d}_{50}$ between $7 \mu \mathrm{m}$ to $22 \mu \mathrm{m}$, depending on the fuel type, quantity of Plum Run dolomite utilized for sulfur control, and whether solids were being recirculated from the dipleg back into 


\section{DRAFT}

TABLE 12

TRDU Actual Operating Conditions

\begin{tabular}{lcccc}
\hline Parameter & P056 and P057 & P056 & P057 & P058 \\
\hline Conditions & Gasification & Gasification & Gasification & Combustion \\
Coal & Wyodak & Illinois No. 6 & SUFCo & Pet Coke \\
Moisture Content, \% & 20.0 & 8.5 & 9.5 & 0.9 \\
Pressure, bar & 9.3 & 9.3 & 9.3 & 8.6 \\
Steam:Coal Ratio (lb/lb coal) & 0.29 & 0.39 & $0.14-0.41$ & 0 \\
Air:Coal Ratio (lb/lb coal) & 2.69 & 2.59 & $3.34-3.45$ & $15-20$ \\
Ca:S Mole Ratio, (sorbent) & 2.0 & 2.0 & 2.0 & 1.0 \\
Coal Feed Rate, lb/hr & 276.6 & 232.5 & 220 & 50 \\
J-leg Zone, ${ }^{\circ} \mathrm{C}$, avg. & 800 & 901 & $866-876$ & 814 \\
Mixing Zone, ${ }^{\circ} \mathrm{C}$, avg. & 850 & 935 & $920-950$ & 835 \\
Riser, ${ }^{\circ} \mathrm{C}$, avg. & 840 & 923 & $894-914$ & 873 \\
Standpipe, ${ }^{\circ} \mathrm{C}$, avg. & 790 & 856 & $828-860$ & 827 \\
Dipleg, ${ }^{\circ} \mathrm{C}$, avg. & 600 & 576 & $555-591$ & 471 \\
TRDU Outlet, ${ }^{\circ} \mathrm{C}$, avg. & 795 & 870 & $856-877$ & 835 \\
Carbon Conversion, $\%$ & 89 & 76 & $72-87$ & 100 \\
Carbon in Bed, \%, Standpipe & $6-15$ & $6-15$ & $5-20$ & 0 \\
Riser Velocity, ft/s & 30 & 24 & $25-31$ & 24.5 \\
Standpipe Velocity, ft/s & $0.4-0.5$ & .45 & $0.4-0.45$ & $0.45-0.5$ \\
Circulation Rate, lb/hr & $3000-6000$ & 4000 & $2650-4200$ & $2000-4000$ \\
HHV of Fuel Gas, act., & $62-75$ & 61 & $52-75$ & NA \\
Btu/scf, cor., Btu/scf & $105-117$ & 113 & $93-130$ & \\
Duration, hr & 179 & 41 & 118 & 70 \\
Date & $2 / 17-2 / 23$ and & $2 / 23-2 / 25$ & $4 / 3-4 / 8$ & $5 / 1-5 / 4$ \\
& $3 / 31-4 / 3$ & & & \\
\hline
\end{tabular}

the standpipe. A substantial increase in the "cleaned" filter baseline (from $\sim 25$ to 90 " $\mathrm{H}_{2} \mathrm{O}$ ) has been observed in some but not all of the tests. This filter ash averaged 40 to $60 \mathrm{wt} \%$ carbon and had a low bulk density of approximately $20 \mathrm{lb} / \mathrm{ft}^{3}$. The small size, the lack of the cohesiveness seen in other filter ashes, and the low density of the ash suggests that a high percentage of the filter cake will be reentrained back onto the filters after they are backpulsed. Off-line cleaning tests were completed which indicated that 20 to 25 inches of the baseline increase is due to reentrainment of fine filter ash back on the candles and that off-line cleaning times up to $300 \mathrm{sec}$ were needed to allow the backpulsed ash to clear the filters. In gasification mode, the pulse frequency has been short, with pulses occurring every 8 to 15 minutes. This rapid pulsing is thought to be due to the high-carbon, low-density filter cake being able to minimize its porosity on the surface of the candle thereby resulting in a rapid rise in pressure drop across the filters. Injection of filter aid additives has been tested with some success: no additives have increased the backpulsing frequency but some have reduced or eliminated the rise in baseline pressure drop. The additives that appeared to help reduce baseline pressure drop include a fluid catalytic cracking (FCC) catalyst support material and combustion coal ash from the Southern Company Services (SCS) Power Systems Development Facility (PSDF) transport reactor (when fed at relatively high rates). 


\section{DRAFT}

\subsubsection{TRDU Deposit Formation}

During the last 30 hours of Test P051, a gas purge of nitrogen to the transition from the horizontal riser to the vertical inlet of the disengager cyclone was shut off. It appears that the presence of this purge is enough to keep the deposits which formed in this area from occurring, since approximately 12 hours after shutting the purge down some process upsets occurred which would be indicative of some type of deposit forming in this area. These deposits were formed at a relatively low temperature of $825^{\circ}$ to $875^{\circ} \mathrm{C}$ in an area where the gas and solid flow make a $90^{\circ}$ turn using a flooded tee. The deposits were white in color on the inside edge where they were exposed to air during shutdown, while the outside edge was black in color due to the carbon contained in the deposit which did not get exposed to air during the shutdown. Table 13 shows the bulk chemical composition of various Wyodak fuel steady-state solid samples obtained from the TRDU during the time period that these deposits formed. The standpipe sample is the material large enough to be removed by the disengager cyclone, while the dipleg material is the finer material removed by the primary cyclone and the filter sample is the finest-size material removed by the hot-gas filter on the system. The material flowing past the deposition point in the TRDU riser is the sum of all three samples.

TABLE 13

XRF Chemical Composition of TRDU Samples

Test P051 (2/27/97)

\begin{tabular}{lcccr}
\hline Element & Coal Ash & Standpipe & Dipleg & Filter \\
\hline $\mathrm{Si}$ & 19.7 & 37.0 & 21.6 & 16.6 \\
$\mathrm{Al}$ & 10.5 & 4.8 & 5.5 & 9.5 \\
$\mathrm{Fe}$ & 4.2 & 4.0 & 5.1 & 10.1 \\
$\mathrm{Ti}$ & 1.0 & 0.6 & 0.8 & 1.6 \\
$\mathrm{P}$ & 0.5 & 0.1 & 0.2 & 0.6 \\
$\mathrm{Ca}$ & 41.4 & 38.5 & 47.4 & 48.3 \\
$\mathrm{Mg}$ & 13.3 & 13.1 & 17.7 & 10.9 \\
$\mathrm{Na}$ & 1.4 & 0.8 & 0.6 & 0.3 \\
$\mathrm{~K}$ & 0.5 & 0.2 & 0.1 & 0.2 \\
$\mathrm{~S}$ & 7.7 & 0.9 & 0.9 & 1.9 \\
Total & 100.0 & 100.0 & 99.9 & 100.0 \\
\hline
\end{tabular}

Figures 10 and 11 are photographs showing some of the points which were analyzed. Table 14 shows the elemental analysis of the interstitial "glue" used to hold the deposit together. A comparison of the glue chemistry with that of the bulk samples from the TRDU indicates that the glue is enriched in the smallest ash particles, particularly the high concentration of organically associated calcium which should form very fine aerosols. There did not appear to be any appreciable sulfur in either the white oxidized layer or the black carbonaceous layer of the deposit, perhaps suggesting that the formation of a sticky calcium sulfide is not a major 


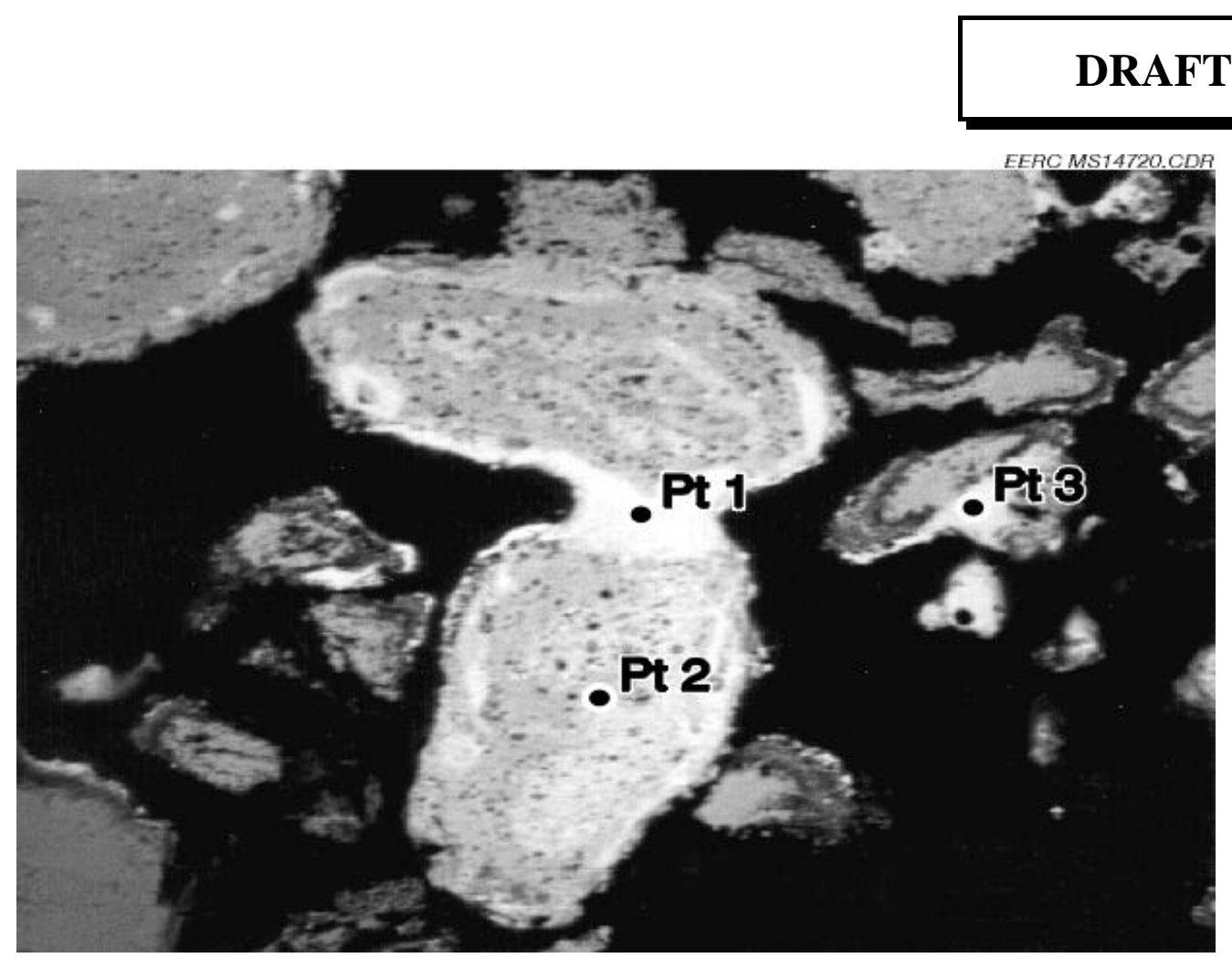

Figure 10. SEM photomicrograph of TRDU deposit showing Points 1-3.

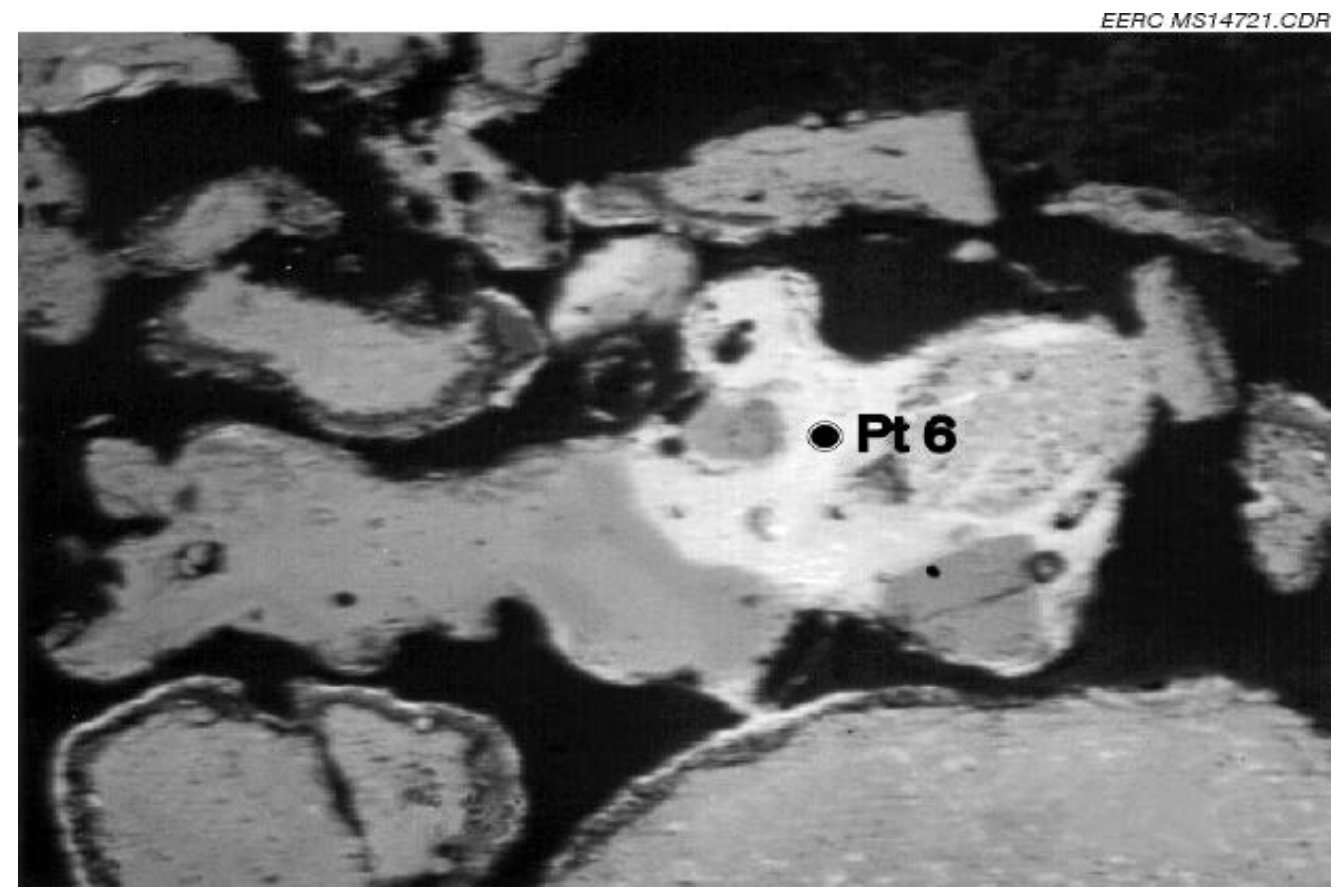

Figure 11. SEM photomicrograph of TRDU deposit showing Point 6. 


\section{DRAFT}

TABLE 14

SEM Morphology Analysis of TRDU Riser Deposits from Test P051

\begin{tabular}{lrrrr}
\hline SEM Point Number: & 1 & 3 & 5 & 6 \\
Description: & With Dolomite & $\begin{array}{c}\text { With } \\
\text { Dolomite }\end{array}$ & $\begin{array}{c}\text { With } \\
\text { Silica Sand }\end{array}$ & $\begin{array}{c}\text { With Silica- } \\
\text { Dolomite }\end{array}$ \\
\hline Normalized Elemental wt\% & & & & \\
$\mathrm{Na}$ & 1.9 & 0.0 & 0.0 & 0.0 \\
$\mathrm{Mg}$ & 2.8 & 1.3 & 2.3 & 0.0 \\
$\mathrm{Al}$ & 5.7 & 22.5 & 7.4 & 2.2 \\
$\mathrm{Si}$ & 20.3 & 10.7 & 11.8 & 18.0 \\
$\mathrm{P}$ & 0.8 & 0.7 & 0.4 & 0.5 \\
$\mathrm{~S}$ & 0.6 & 0.0 & 0.3 & 0.0 \\
$\mathrm{~K}$ & 0.6 & 0.4 & 0.0 & 0.7 \\
$\mathrm{Ca}$ & 59.3 & 51.6 & 59.2 & 71.7 \\
$\mathrm{Ti}$ & 1.3 & 1.1 & 1.9 & 0.5 \\
$\mathrm{Fe}$ & 4.4 & 11.6 & 11.9 & 3.3 \\
$\mathrm{Ba}$ & 2.3 & 0.0 & 4.9 & 3.1 \\
$\mathrm{Total}$ & 100.0 & 99.9 & 100.1 & 100.0 \\
\hline
\end{tabular}

mechanism for the deposit formation. The presence of very small mineral particles, especially high concentrations of kaolinite $\left(\mathrm{Al}_{4} \mathrm{Si}_{4} \mathrm{O}_{10}[\mathrm{OH}]_{8}\right)$ and the fact that the organically associated calcium will form vapor or very fine aerosols can lead to the formation of lower melting aluminosilicates such as calcium aluminosilicates and montmorillonite $\left([0.5 \mathrm{Ca}, \mathrm{Na}]_{0.7}[\mathrm{Al} . \mathrm{Mg}, \mathrm{Fe}]_{4}[\mathrm{Si}, \mathrm{Al}]_{8} \mathrm{O}_{20}\right)$. Previous tests using this same coal showed significant increases in calcium aluminosilicates and montmorillonite in the hot-gas filter ash (i.e., the smallest particle sizes), suggesting the formation of these compounds under the operating conditions of the TRDU. These data suggest that the "glue" appears to be a calcium aluminosilicate that was, possibly, the result of vapor-phase calcium from the organically associated calcium in the coal reacting directly with the fine coal/ash to form a low-melting eutectic coating on the bed material and dolomite particles.

Two other gasification tests were performed using the Wyodak subbituminous coal, with a short test approximately 6 hours long trying to feed an Illinois No. 6 bituminous coal to the TRDU. At the end of this test, some deposits were found in the mixing section and burner throat

Figure 12 is a photograph of a deposit from the mixing zone of the TRDU showing some of the points analyzed by SEM morphology. Tables 15 and 16 show the elemental chemical 


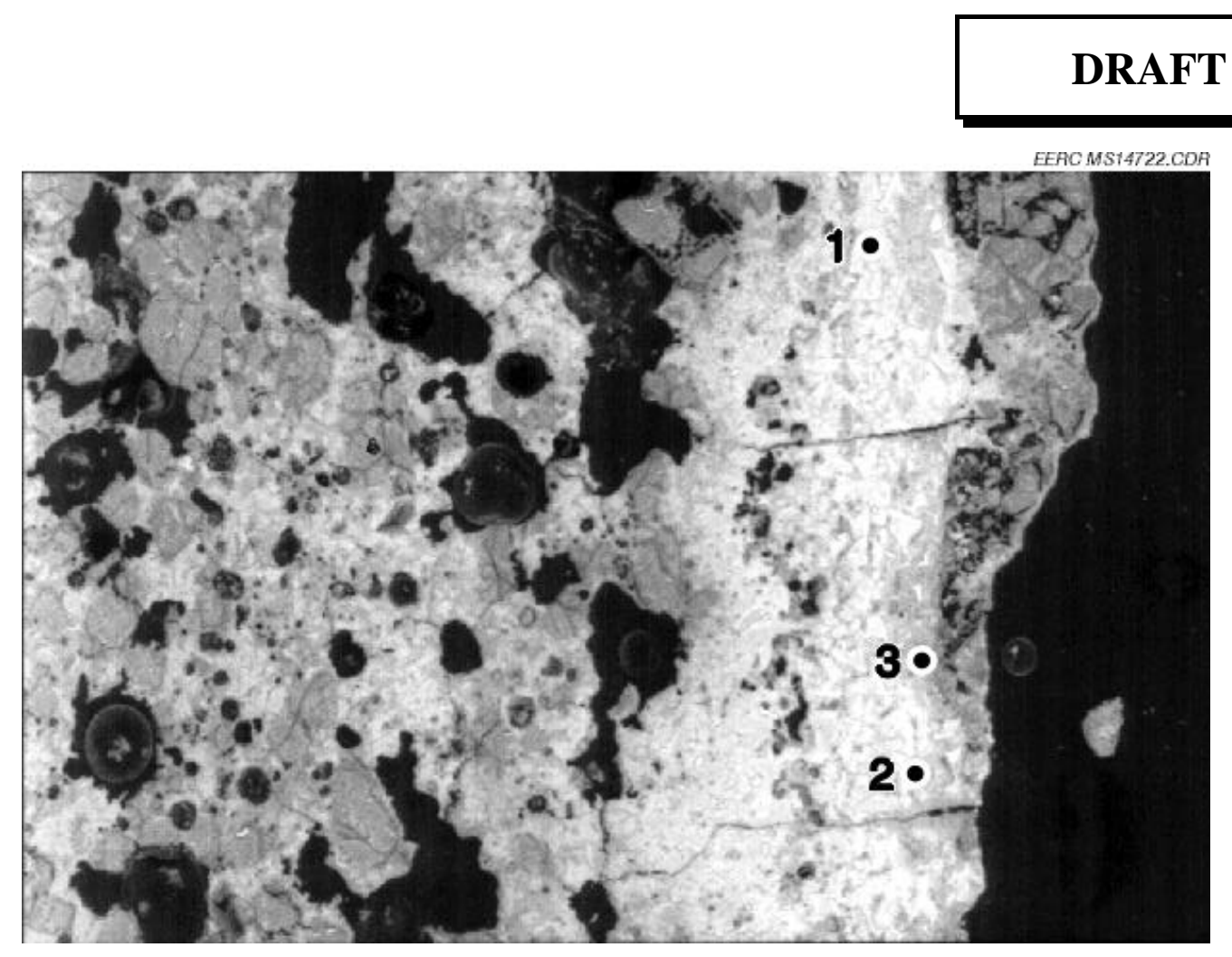

Figure 12. SEM photomicrograph of a deposit from the mixing zone of the TRDU.

composition of these points. It was found that chemical composition toward the inside edge of these deposits was substantially higher in iron than the outer edge (which probably started forming using the low-iron Wyodak coal) and previous deposits obtained from the TRDU.

The additional tests performed during the past year have all had episodes of deposit formation that have resulted in shutdown of the TRDU system to remove these deposits. The deposits that formed were generally in the mixing zone where the air first enters the TRDU through the burner inlet and comes into contact with the carbon-containing bed material circulating through the J-leg. If the solid-gas mixing is not adequate, localized hot spots can occur. As a result, some of the coal ash can reach temperatures where a sticky layer around bed material particles can form and start to "glue" impacting particles together in the form of deposits or agglomerates. Conventional bulk chemical analysis of deposits provides an analysis of the entire deposit when only the sticky layer on the outer surface bed material particle that is of concern. Figure 13 compares a deposit from the Illinois No. 6 coal in the burner region of the TRDU as analyzed by XRF with a manual SEMPC analysis of only the outer layers found on bed material particles and compares them to the coal ash analysis. As can be seen, the coal ash analysis and the SEMPC analysis are very similar, while the XRF analysis includes a lot of the bed material in the analysis. As shown in Figure 13, the Illinois No. 6 ash deposit is high in iron, calcium, magnesium, and sulfur with the analysis of the necks by SEM showing an enrichment in iron and sulfur over the bulk XRF analysis. Figure 14 shows a comparison of the SEMPC data for the three different fuels. From this figure, it appears the deposition chemistry of the Wyodak and SUFCo fuels is similar, primarily being calcium aluminosilicates with little or no sulfur present in the deposit. The Illinois No. 6 deposit, however, is much higher in iron and sulfur from the pyrite 


\section{DRAFT}

present in the coal, while containing less silica. Table 17 shows the bulk chemical analysis and SEMPC analyses of deposits obtained during the gasification test completed on the

TABLE 15

SEM Morphology Analysis of TRDU Burner Throat Deposits from Test P055

\begin{tabular}{|c|c|c|c|c|c|c|}
\hline $\begin{array}{l}\text { SEM Point Number: } \\
\text { Description: }\end{array}$ & $\begin{array}{c}521-a-1 \\
\text { Fill }\end{array}$ & $\begin{array}{c}521-\mathrm{a}-2 \\
\text { Fill }\end{array}$ & $\begin{array}{c}521-a-3 \\
\text { Fill }\end{array}$ & $\begin{array}{l}521-\mathrm{b}-1 \\
\text { Fill }\end{array}$ & $\begin{array}{c}\text { 521-b-2 } \\
\text { Fill }\end{array}$ & $\begin{array}{l}522-1 \\
\text { Neck }\end{array}$ \\
\hline \multicolumn{7}{|c|}{ Normalized Elemental wt\% } \\
\hline $\mathrm{Na}$ & 0.6 & 1.5 & 0.1 & 1.9 & 1.0 & 1.2 \\
\hline $\mathrm{Mg}$ & 2.2 & 10.6 & 2.2 & 4.6 & 8.9 & 8.7 \\
\hline $\mathrm{Al}$ & 2.7 & 5.8 & 0.7 & 10.4 & 4.2 & 2.1 \\
\hline $\mathrm{Si}$ & 38.5 & 50.3 & 38.0 & 46.9 & 47.5 & 51.1 \\
\hline $\mathrm{P}$ & 0.0 & 0.3 & 0.1 & 0.1 & 0.0 & 0.5 \\
\hline $\mathrm{S}$ & 0.2 & 0.0 & 0.0 & 0.2 & 0.1 & 0.0 \\
\hline $\mathrm{K}$ & 0.6 & 2.4 & 0.0 & 1.0 & 2.6 & 0.5 \\
\hline $\mathrm{Ca}$ & 42.2 & 26.2 & 58.1 & 28.5 & 28.0 & 30.6 \\
\hline $\mathrm{Ti}$ & 1.1 & 0.1 & 0.1 & 1.1 & 0.7 & 0.7 \\
\hline $\mathrm{Fe}$ & 9.4 & 2.5 & 0.1 & 5.1 & 6.0 & 4.2 \\
\hline $\mathrm{Ba}$ & 2.6 & 0.3 & 0.6 & 0.3 & 0.9 & 0.6 \\
\hline Total & 100.1 & 100.0 & 100.0 & 100.1 & 99.9 & 100.2 \\
\hline
\end{tabular}

TABLE 16

$\underline{\text { SEM Morphology Analysis of TRDU Mixing Zone Deposits from Test P055 }}$

\begin{tabular}{lrrr}
\hline SEM Point Number: & $520-1$ & $520-2$ & $520-3$ \\
Description: & Fill & Fill & Fill \\
\hline Normalized Elemental wt\% & & & \\
$\mathrm{Na}$ & 0.0 & 0.0 & 0.4 \\
$\mathrm{Mg}$ & 12.4 & 23.9 & 15.6 \\
$\mathrm{Al}$ & 14.7 & 4.3 & 6.4 \\
$\mathrm{Si}$ & 8.3 & 9.7 & 10.0 \\
$\mathrm{P}$ & 0.2 & 0.0 & 0.3 \\
$\mathrm{~S}$ & 0.7 & 2.1 & 4.7 \\
$\mathrm{~K}$ & 0.0 & 0.0 & 0.3 \\
$\mathrm{Ca}$ & 51.2 & 41.5 & 45.0 \\
$\mathrm{Ti}$ & 2.4 & 1.4 & 1.4 \\
$\mathrm{Fe}$ & 8.7 & 17.0 & 14.9 \\
$\mathrm{Ba}$ & 1.6 & 0.0 & 0.9 \\
Total & & & \\
\hline
\end{tabular}




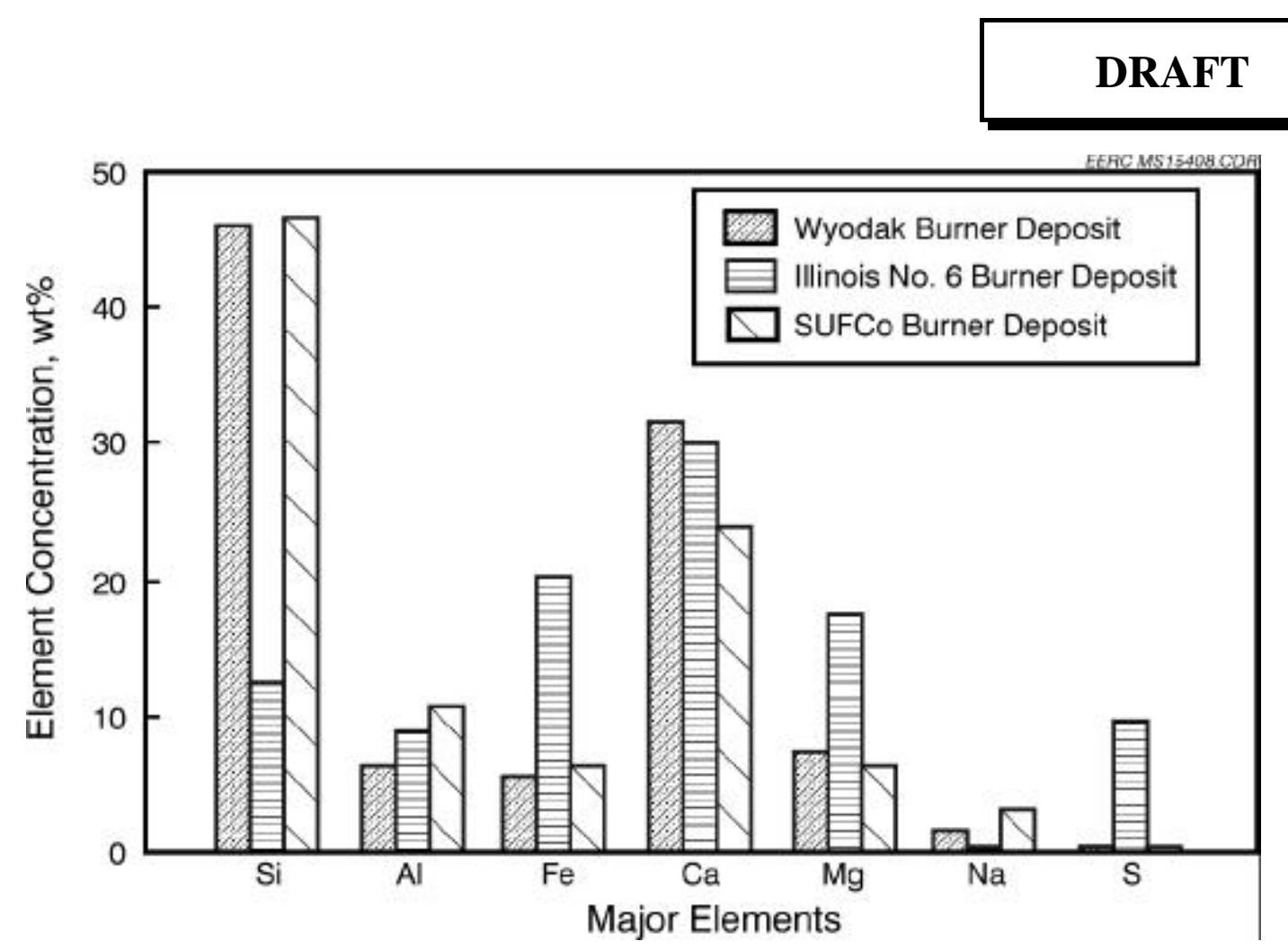

Figure 13. Comparison of Illinois No. 6 deposit analyses.

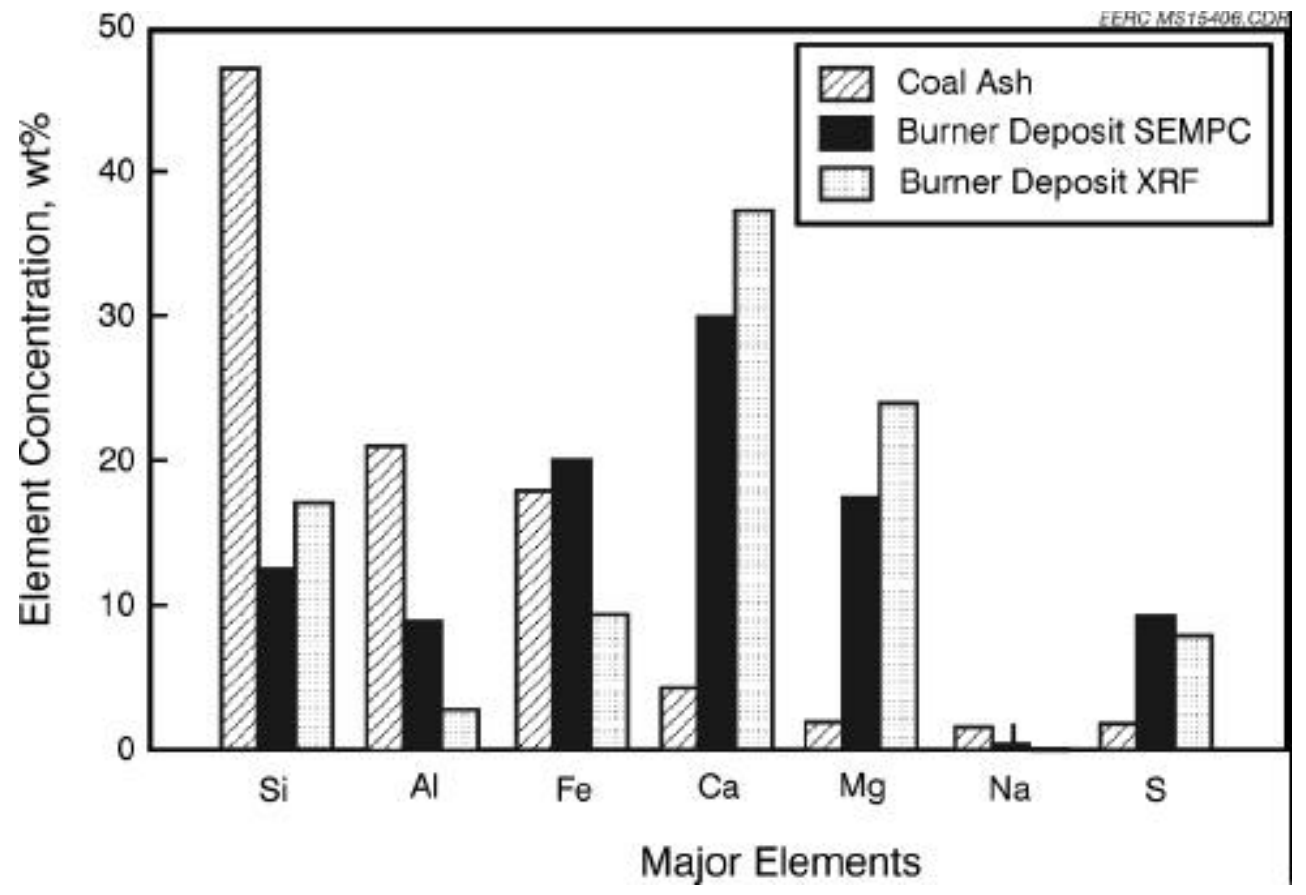

Figure 14. Comparison of SEMPC analyses of burner deposits for various fuels tested in TRDU. 


\section{DRAFT}

\section{TABLE 17}

XRF and SEMPC Data from TRDU Mixing Zone Deposits Formed from Wyodak Coal

$\begin{array}{lllll}\text { XRF Wyodak } & \text { PCT 980403 } & \text { XRF 2/21/98 } & \text { PCT 980404 } & \text { XRF 4/1/98 }\end{array}$

\begin{tabular}{lcrrrr} 
wt\% & Coal Ash & Wyodak SP Dep. & Wyodak SP Dep. & Wyodak Burn Dep. Wyodak Burn Dep. \\
\hline $\mathrm{Si}$ & 23.0 & 49.4 & 83.4 & 46.0 & 90.3 \\
$\mathrm{Al}$ & 12.5 & 6.7 & 1.5 & 6.1 & 1.7 \\
$\mathrm{Fe}$ & 6.9 & 9.8 & 1.6 & 5.4 & 1.9 \\
$\mathrm{Ti}$ & 1.4 & 0.9 & 0.2 & 0.7 & 0.2 \\
$\mathrm{P}$ & 0.8 & 0.2 & 0.0 & 0.2 & 0.1 \\
$\mathrm{Ca}$ & 34.2 & 26.7 & 8.8 & 31.5 & 4.8 \\
$\mathrm{Mg}$ & 7.6 & 3.4 & 3.9 & 7.2 & 0.5 \\
$\mathrm{Na}$ & 1.7 & 1.2 & 0.0 & 1.3 & 0.2 \\
$\mathrm{~K}$ & 0.4 & 0.2 & 0.2 & 0.6 & 0.1 \\
$\mathrm{~S}$ & 11.5 & 0.4 & 0.2 & 0.2 & 0.2 \\
$\mathrm{Ba}$ & & 0.9 & & 0.8 & 100.0 \\
Total & 100.0 & 99.8 & 99.8 & 100.0 & \\
\hline
\end{tabular}

TABLE 18

Comparison of XRF and SEMPC Data on Burner Deposits from Illinois No. 6 Fuel

\begin{tabular}{lccccccc}
\hline & XRF & XRF & PCT & PCT & PCT & PCT & PCT \\
& Illinois & 2/25/98 & 980402a & 980402b & 980402c & 980402d & 980402e \\
& No. 6 & Illinois No. 6 & Illinois No. 6 & Illinois No. 6 & Illinois No. 6 & Illinois No. 6 & Illinois No. 6 \\
wt\% & Coal Ash & Burn Dep. & Burn Dep. & Burn Dep. & Burn Dep. & Burn Dep. & Burn Dep. \\
\hline $\mathrm{Si}$ & 47.4 & 17.1 & 13.2 & 12.4 & 12.2 & 12.0 & 12.6 \\
$\mathrm{Al}$ & 21.1 & 2.9 & 4.4 & 8.5 & 12.1 & 11.1 & 8.4 \\
$\mathrm{Fe}$ & 17.9 & 9.5 & 24.3 & 21.3 & 14.8 & 19.8 & 20.3 \\
$\mathrm{Ti}$ & 1.0 & 0.2 & 0.2 & 1.0 & 0.3 & 0.3 & 0.9 \\
$\mathrm{P}$ & 0.1 & 0.1 & 0.1 & 0.1 & 0.1 & 0.1 & 0.1 \\
$\mathrm{Ca}$ & 4.4 & 37.7 & 29.3 & 29.5 & 33.3 & 29.4 & 28.8 \\
$\mathrm{Mg}$ & 1.8 & 24.0 & 13.5 & 19.3 & 16.8 & 17.2 & 20.7 \\
$\mathrm{Na}$ & 1.6 & 0.2 & 0.6 & 0.4 & 0.3 & 0.4 & 0.3 \\
$\mathrm{~K}$ & 2.9 & 0.5 & 0.5 & 0.2 & 0.1 & 0.4 & 0.1 \\
$\mathrm{~S}$ & 1.9 & 7.8 & 13.6 & 6.9 & 9.9 & 9.0 & 7.5 \\
$\mathrm{Ba}$ & & & 0.1 & 0.1 & 0.3 & 0.2 & 0.1 \\
Total & 100.1 & 100.0 & 99.8 & 99.7 & 100.2 & 99.9 & 99.8 \\
\hline
\end{tabular}




\section{DRAFT}

Wyodak fuel during Test P056. The SEM analysis shows much less silica since it was looking only at the necks and fill material between the bed material particles. Table 18 shows the comparison of the XRF and SEMPC data for the Illinois No. 6 burner deposit. Again, the SEMPC data are much more indicative of the material that is holding the deposit together than the XRF analysis. Table 19 shows the same comparison for the SUFCo coal mixing zone deposits. These analyses indicate that the deposit is similar to the Wyodak coal deposits since a calcium aluminosilicate comprises the glue which holds the bed material particles together. Tables 20 through 24 show the SEM morphology data from several deposits analyzed for the chemistry of the fill material. For the deposits from the Wyodak or SUFCo coals, the layers around or fill material between the bed material particles are predominately calcium silicate material with lesser amounts of iron, magnesium, alumina, and small levels of sodium in the case of the SUFCo deposits. These low-melting eutectics have very similar chemistry for the two low-sulfur fuels. The high-sulfur Illinois No. 6 fuel does have a different deposit chemistry, with high levels of iron sulfide being present in the deposits. The existence of iron sulfide has been documented in other gasification systems (3). Figures 15 through 22 are SEM photographs of TRDU mixing zone deposits and some of the points analyzed by the SEM microprobe. The SEM morphology analyses also provided an estimate of the degree of deposit sintering by looking at deposit porosity. A comparison of the porosity of the deposits as determined by image analysis on the SEM shows that the Wyodak and SUFCo coal deposits have a lot more porosity ( 52.2 and 43.2\%, respectively) than the Illinois No. 6 deposit ( 24.3\%). This is consistent with the observation that the Illinois No. 6 ash deposit was much harder and more sintered than the deposits from the Wyodak or SUFCo fuels. Circulation rate tests on the SUFCo fuel have shown that deposition at similar operating conditions can be eliminated with the improved solid-gas mixing that occurs at higher circulation rates. The Illinois No. 6 deposits also might be eliminated by operation of the TRDU at higher circulation rates.

\section{TABLE 19}

Comparison of XRF and SEMPC Data on Mixing Zone Deposits from SUFCo Fuel

\begin{tabular}{|c|c|c|c|c|c|c|}
\hline $\mathrm{wt} \%$ & $\begin{array}{c}\text { XRF } \\
\text { SUFCo } \\
\text { Coal Ash } \\
\end{array}$ & $\begin{array}{l}\text { PCT } 980401 \\
\text { SUFCo J-leg } \\
\text { Dep. } \\
\end{array}$ & $\begin{array}{c}\text { XRF 4/5/98 } \\
\text { SUFCo J-leg } \\
\text { Dep. } \\
\end{array}$ & $\begin{array}{l}\text { PCT } 980400 \\
\text { SUFCo Burn } \\
\text { Dep. } \\
\end{array}$ & $\begin{array}{c}\text { XRF 4/5/98 } \\
\text { SUFCo Burn } \\
\text { Dep. } \\
\end{array}$ & $\begin{array}{c}\text { PCT - Avg. } \\
\text { 980400\&401 SUFCo } \\
\text { J\&Burn Dep. }\end{array}$ \\
\hline SI & 33.7 & 48.1 & 62.5 & 45.5 & 59.5 & 46.8 \\
\hline $\mathrm{Al}$ & 9.2 & 10.7 & 10.3 & 10.7 & 8.3 & 10.7 \\
\hline $\mathrm{Fe}$ & 8.0 & 5.6 & 5.2 & 7.1 & 5.2 & 6.35 \\
\hline $\mathrm{Ti}$ & 0.9 & 1.1 & 0.6 & 0.6 & 0.5 & 0.85 \\
\hline $\mathrm{P}$ & 0.2 & 0.2 & 0.1 & 0.2 & 0.1 & 0.2 \\
\hline $\mathrm{Ca}$ & 21.9 & 23.0 & 12.8 & 24.6 & 17.0 & 23.8 \\
\hline $\mathrm{Mg}$ & 3.5 & 6.2 & 4.3 & 6.5 & 5.9 & 6.35 \\
\hline $\mathrm{Na}$ & 6.5 & 3.2 & 2.7 & 2.8 & 2.1 & 3.0 \\
\hline $\mathrm{K}$ & 0.3 & 1.3 & 1.3 & 1.1 & 0.9 & 1.2 \\
\hline S & 15.9 & 0.2 & 0.2 & 0.3 & 0.6 & 0.25 \\
\hline $\mathrm{Ba}$ & NA & 0.3 & $\mathrm{NA}$ & 0.4 & NA & 0.35 \\
\hline Total & 100.1 & 99.9 & 100.0 & 99.8 & 100.1 & 99.85 \\
\hline
\end{tabular}




\section{DRAFT}

TABLE 20

SEM Morphology Analysis of TRDU Standpipe Deposits from Wyodak Coal Gasification Test P056 2/21/98 (Sample 98-0403)

\begin{tabular}{|c|c|c|c|c|c|c|c|c|}
\hline $\begin{array}{l}\text { SEM Point No.: } \\
\text { Description: }\end{array}$ & $\begin{array}{c}1 \\
\text { Fill }\end{array}$ & $\begin{array}{c}2 \\
\text { Fill }\end{array}$ & $\begin{array}{c}3 \\
\text { Fill }\end{array}$ & $\begin{array}{c}7 \\
\text { Fill }\end{array}$ & $\begin{array}{c}8 \\
\text { Fill }\end{array}$ & $\begin{array}{c}10 \\
\text { Neck }\end{array}$ & $\begin{array}{c}11 \\
\text { Neck }\end{array}$ & $\begin{array}{c}12 \\
\text { Layer }\end{array}$ \\
\hline \multicolumn{9}{|c|}{ Normal $\mathrm{O}_{2}$-Free Element, wt $\%$} \\
\hline $\mathrm{Na}$ & 0.4 & 0.7 & 2.5 & 1.0 & 0.1 & 0.2 & 0.1 & 0.4 \\
\hline $\mathrm{Mg}$ & 12.2 & 5.4 & 5.0 & 4.2 & 4.4 & 4.4 & 4.0 & 3.7 \\
\hline $\mathrm{Al}$ & 1.1 & 13.4 & 10.2 & 4.2 & 4.8 & 5.1 & 5.2 & 5.2 \\
\hline $\mathrm{Si}$ & 26.1 & 31.6 & 44.1 & 47.8 & 41.5 & 53.5 & 53.7 & 54.2 \\
\hline $\mathrm{P}$ & 0.5 & 0.4 & 0.0 & 0.2 & 0.1 & 0.0 & 0.1 & 0.0 \\
\hline S & 0.5 & 1.6 & 1.3 & 0.0 & 1.4 & 0.0 & 0.3 & 0.0 \\
\hline $\mathrm{Cl}$ & 0.0 & 0.1 & 0.4 & 0.0 & 0.0 & 0.2 & 0.1 & 0.0 \\
\hline $\mathrm{K}$ & 0.0 & 0.0 & 0.7 & 0.0 & 0.0 & 0.0 & 0.0 & 0.3 \\
\hline $\mathrm{Ca}$ & 58.5 & 39.5 & 30.8 & 29.4 & 32.0 & 31.2 & 31.0 & 31.8 \\
\hline $\mathrm{Ti}$ & 0.6 & 2.1 & 1.0 & 6.3 & 9.9 & 0.4 & 1.1 & 0.9 \\
\hline $\mathrm{Fe}$ & 0.1 & 3.1 & 4.1 & 6.1 & 5.8 & 3.7 & 4.0 & 2.5 \\
\hline $\mathrm{Ba}$ & 0.0 & 2.1 & 0.0 & 0.8 & 0.0 & 1.3 & 0.6 & 1.0 \\
\hline Total & 100.0 & 100.1 & 100.1 & 100.0 & 100.2 & 100.1 & 100.0 & 100.0 \\
\hline
\end{tabular}

TABLE 21

SEM Morphology Analysis of TRDU Burner Deposits from SUFCo Coal Gasification Test P057 4/5/98 (Sample 98-0400)

\begin{tabular}{|c|c|c|c|c|c|}
\hline $\begin{array}{l}\text { SEM Point No.: } \\
\text { Description: }\end{array}$ & $\begin{array}{l}1.1 \\
\text { Fill }\end{array}$ & $\begin{array}{l}3.2 \\
\text { Fill }\end{array}$ & $\begin{array}{l}4.1 \\
\text { Fill }\end{array}$ & $\begin{array}{l}4.2 \\
\text { Fill }\end{array}$ & $\begin{array}{c}8 \\
\text { Fill }\end{array}$ \\
\hline \multicolumn{6}{|c|}{ Normal $\mathrm{O}_{2}$-Free Element, wt $\%$} \\
\hline $\mathrm{Na}$ & 1.4 & 3.4 & 1.5 & 1.5 & 2.3 \\
\hline $\mathrm{Mg}$ & 8.4 & 3.4 & 6.4 & 8.3 & 1.1 \\
\hline $\mathrm{Al}$ & 11.2 & 11.7 & 7.1 & 7.3 & 23.0 \\
\hline $\mathrm{Si}$ & 39.8 & 43.8 & 35.0 & 36.1 & 41.8 \\
\hline $\mathrm{P}$ & 0.4 & 0.4 & 0.2 & 0.2 & 0.1 \\
\hline S & 0.1 & 0.3 & 0.2 & 0.2 & 0.0 \\
\hline $\mathrm{Cl}$ & 0.2 & 0.1 & 0.2 & 0.2 & 0.1 \\
\hline $\mathrm{K}$ & 0.2 & 0.6 & 0.7 & 0.6 & 0.5 \\
\hline $\mathrm{Ca}$ & 27.8 & 21.5 & 25.5 & 25.9 & 21.8 \\
\hline $\mathrm{Ti}$ & 2.1 & 1.8 & 1.8 & 1.1 & 0.4 \\
\hline $\mathrm{Fe}$ & 8.2 & 12.5 & 21.5 & 18.5 & 8.8 \\
\hline $\mathrm{Mn}$ & 0.1 & 0.4 & 0.0 & 0.3 & 0.0 \\
\hline $\mathrm{Ni}$ & 0.0 & 0.0 & 0.0 & 0.0 & 0.3 \\
\hline $\mathrm{V}$ & 0.1 & 0.1 & 0.0 & 0.0 & 0.0 \\
\hline Total & 100.0 & 100.1 & 100.1 & 100.0 & 100.2 \\
\hline
\end{tabular}




\section{DRAFT}

TABLE 22

SEM Morphology Analysis of TRDU Burner Deposits from Wyodak Coal Gasification

Test P057 (Sample 98-0404)

\begin{tabular}{|c|c|c|c|c|c|c|c|c|c|c|}
\hline $\begin{array}{l}\text { SEM Point No.: } \\
\text { Description: }\end{array}$ & $\begin{array}{c}1 \\
\text { Fill }\end{array}$ & $\begin{array}{c}2 \\
\text { Fill }\end{array}$ & $\begin{array}{c}3 \\
\text { Fill }\end{array}$ & $\begin{array}{c}5 \\
\text { Neck }\end{array}$ & $\begin{array}{c}6 \\
\text { Neck }\end{array}$ & $\begin{array}{c}7 \\
\text { Fill }\end{array}$ & $\begin{array}{c}8 \\
\text { Fill }\end{array}$ & $\begin{array}{c}9 \\
\text { Fill }\end{array}$ & $\begin{array}{c}10 \\
\text { Neck }\end{array}$ & $\begin{array}{c}11 \\
\text { Neck }\end{array}$ \\
\hline \multicolumn{11}{|l|}{$\begin{array}{l}\text { Normal } \mathrm{O}_{2} \text {-Free } \\
\text { Element, wt } \%\end{array}$} \\
\hline $\mathrm{Na}$ & 1.0 & 0.9 & 0.8 & 0.9 & 2.3 & 0.4 & 0.5 & 0.0 & 0.7 & 0.4 \\
\hline $\mathrm{Mg}$ & 9.3 & 5.7 & 7.3 & 5.3 & 3.2 & 3.9 & 0.2 & 0.7 & 7.2 & 0.5 \\
\hline $\mathrm{Al}$ & 5.2 & 4.6 & 1.5 & 6.9 & 11.0 & 2.4 & 15.0 & 8.8 & 5.3 & 5.6 \\
\hline $\mathrm{Si}$ & 40.6 & 44.7 & 41.0 & 42.6 & 44.9 & 26.8 & 26.1 & 27.0 & 49.7 & 49.5 \\
\hline $\mathrm{P}$ & 0.0 & 0.2 & 0.3 & 0.0 & 0.0 & 0.2 & 1.4 & 0.8 & 0.6 & 0.0 \\
\hline S & 0.4 & 0.2 & 0.0 & 0.1 & 0.1 & 0.2 & 0.0 & 5.5 & 0.3 & 0.2 \\
\hline $\mathrm{Cl}$ & 0.3 & 0.5 & 0.0 & 0.3 & 0.2 & 0.0 & 0.2 & 0.1 & 0.2 & 0.0 \\
\hline $\mathrm{K}$ & 0.1 & 0.3 & 0.0 & 0.3 & 0.0 & 0.0 & 1.1 & 0.2 & 0.0 & 0.4 \\
\hline $\mathrm{Ca}$ & 29.1 & 23.4 & 26.0 & 36.0 & 31.5 & 65.1 & 22.5 & 31.7 & 32.0 & 38.2 \\
\hline $\mathrm{Ti}$ & 0.6 & 0.1 & 0.6 & 0.8 & 1.0 & 0.5 & 2.4 & 1.0 & 0.2 & 0.8 \\
\hline $\mathrm{Fe}$ & 13.5 & 18.1 & 22.4 & 5.2 & 5.2 & 0.5 & 2.5 & 15.4 & 2.7 & 3.0 \\
\hline $\mathrm{Ba}$ & 0.0 & 1.6 & 0.1 & 1.7 & 0.8 & 0.0 & 28.4 & 9.6 & 1.2 & 1.6 \\
\hline Total & 100.0 & 100.1 & 100.1 & 100.1 & 100.1 & 100.0 & 100.2 & 100.1 & 100.0 & 100.0 \\
\hline
\end{tabular}

\subsubsection{Task 3 Results - Alloy Corrosion}

The objective of the alloy corrosion portion of this task is to evaluate and compare the corrosion resistance of superheater and reheater tube materials in the presence of high-alkali ash from low-rank coal. Many studies have been completed in which alloys were subjected to the temperatures and pressures seen in modern and future combustion systems, but very few included the high-alkali ash required to simulate conditions of a coal-fired boiler.

The alloys chosen for the evaluation are TP347HFG, HR3C, RA253MA, and Incoloy $800 \mathrm{HT}$, highly alloyed steels with improved high-temperature corrosion resistance and creep strength. These alloys are expected to allow steam temperatures of up to $630^{\circ} \mathrm{C}$. For each of these steels, there is limited knowledge of their long-term high-temperature corrosion behavior in coal-fired systems. The alloys were selected by reviewing articles published on USC systems, talking with ELSAM engineers, and also reviewing specific studies. 
TABLE 23

SEM Morphology Analysis of TRDU Burner Deposits From Illinois No. 6 Coal Gasification Test P056 (Sample 98-0402)

\begin{tabular}{|c|c|c|c|c|c|c|c|c|c|c|}
\hline $\begin{array}{l}\text { SEM Point No.: } \\
\text { Description: }\end{array}$ & $\begin{array}{c}1 \\
\text { Part }\end{array}$ & $\begin{array}{c}2 \\
\text { Part }\end{array}$ & $\begin{array}{c}3 \\
\text { Fill }\end{array}$ & $\begin{array}{c}4 \\
\text { Part }\end{array}$ & $\begin{array}{c}5 \\
\text { Part }\end{array}$ & $\begin{array}{c}6 \\
\text { Fill }\end{array}$ & $\begin{array}{c}7 \\
\text { Part }\end{array}$ & $\begin{array}{c}8 \\
\text { Fill }\end{array}$ & $\begin{array}{c}9 \\
\text { Part }\end{array}$ & $\begin{array}{l}10 \\
\text { Fill }\end{array}$ \\
\hline \multicolumn{11}{|l|}{$\begin{array}{l}\text { Normal } \mathrm{O}_{2} \text {-Free } \\
\text { Element, wt } \%\end{array}$} \\
\hline $\mathrm{Na}$ & 0.0 & 1.6 & 0.1 & 0.1 & 1.6 & 0.1 & 1.3 & 0.0 & 1.4 & 0.0 \\
\hline $\mathrm{Mg}$ & 0.5 & 0.3 & 28.3 & 0.2 & 1.0 & 11.2 & 0.1 & 11.9 & 51.5 & 11.8 \\
\hline $\mathrm{Al}$ & 0.0 & 0.0 & 0.0 & 0.0 & 0.0 & 0.3 & 0.0 & 0.1 & 11.8 & 0.2 \\
\hline $\mathrm{Si}$ & 0.0 & 0.1 & 28.8 & 0.0 & 1.6 & 24.1 & 0.1 & 27.4 & 0.2 & 27.5 \\
\hline $\mathrm{P}$ & 0.1 & 0.1 & 0.1 & 0.1 & 0.1 & 0.3 & 0.1 & 0.3 & 0.0 & 0.0 \\
\hline S & 44.1 & 37.1 & 1.7 & 43.8 & 34.7 & 0.5 & 37.7 & 0.1 & 0.1 & 0.1 \\
\hline $\mathrm{Cl}$ & 0.0 & 0.0 & 0.0 & 0.0 & 0.0 & 0.0 & 0.0 & 0.0 & 0.0 & 0.1 \\
\hline K & 0.0 & 0.1 & 0.0 & 0.2 & 0.2 & 0.2 & 0.0 & 0.2 & 0.0 & 0.4 \\
\hline $\mathrm{Ca}$ & 53.3 & 0.6 & 39.4 & 53.7 & 4.4 & 62.0 & 0.2 & 58.6 & 0.6 & 58.9 \\
\hline $\mathrm{Ti}$ & 0.0 & 0.0 & 0.0 & 0.1 & 0.0 & 0.0 & 0.0 & 0.2 & 0.1 & 0.0 \\
\hline $\mathrm{Fe}$ & 1.8 & 60.0 & 1.0 & 1.5 & 56.4 & 0.7 & 60.2 & 0.8 & 33.5 & 0.0 \\
\hline $\mathrm{Ba}$ & 0.0 & 0.0 & 0.0 & 0.0 & 0.0 & 0.4 & 0.0 & 0.0 & 0.7 & 0.0 \\
\hline $\mathrm{Cr}$ & 0.1 & 0.1 & 0.4 & 0.1 & 0.1 & 0.0 & 0.0 & 0.2 & 0.1 & 0.4 \\
\hline Total & 100.0 & 99.9 & 100.0 & 99.6 & 100.0 & 99.7 & 99.7 & 99.7 & 100.0 & 99.5 \\
\hline
\end{tabular}


TABLE 24

SEM Morphology Analysis of TRDU Disengager Deposit from Tuscaloosa Petcoke Combustion Test P058

\begin{tabular}{|c|c|c|c|c|c|c|c|c|c|c|c|c|c|}
\hline SEM Point No.: & 1 & 4 & 7 & 8 & 9 & 10 & 11 & 12 & 13 & 14 & 15 & 16 & 18 \\
\hline Description: & Layer & Neck & Fill & Fill & Fill & Fill & Layer & Fill & Fill & Fill & Fill & Fill & Layer \\
\hline \multicolumn{14}{|l|}{$\begin{array}{l}\text { Normal } \mathrm{O}_{2} \text {-Free } \\
\text { Element, wt } \%\end{array}$} \\
\hline $\mathrm{Na}$ & 1.8 & 2.0 & 0.4 & 1.3 & 1.5 & 3.3 & 2.0 & 1.7 & 2.1 & 0.3 & 3.5 & 3.1 & 0.0 \\
\hline $\mathrm{Mg}$ & 0.7 & 0.6 & 6.2 & 1.2 & 1.8 & 0.0 & 0.8 & 3.7 & 1.2 & 16.4 & 0.2 & 0.2 & 0.4 \\
\hline $\mathrm{Al}$ & 4.9 & 7.8 & 26.2 & 10.0 & 7.6 & 39.7 & 7.9 & 6.7 & 3.0 & 2.4 & 17.6 & 14.8 & 0.0 \\
\hline $\mathrm{Si}$ & 45.9 & 57.1 & 21.5 & 47.8 & 48.0 & 41.6 & 55.0 & 50.2 & 16.4 & 43.8 & 35.0 & 25.5 & 24.9 \\
\hline $\mathrm{P}$ & 0.1 & 0.2 & 0.0 & 0.5 & 0.3 & 0.1 & 0.2 & 0.2 & 0.1 & 0.1 & 0.3 & 0.0 & 0.1 \\
\hline$S$ & 0.2 & 0.2 & 0.0 & 0.5 & 0.4 & 0.1 & 0.3 & 0.7 & 0.2 & 0.1 & 10.5 & 16.4 & 0.2 \\
\hline $\mathrm{Cl}$ & 0.1 & 0.1 & 0.1 & 0.0 & 0.1 & 0.0 & 0.0 & 0.2 & 0.0 & 0.1 & 0.1 & 0.0 & 0.0 \\
\hline $\mathrm{K}$ & 1.0 & 2.1 & 0.0 & 0.6 & 0.9 & 0.8 & 1.5 & 1.8 & 0.4 & 0.1 & 0.2 & 0.2 & 0.1 \\
\hline $\mathrm{Ca}$ & 39.5 & 17.5 & 15.5 & 28.1 & 26.0 & 13.4 & 22.6 & 17.7 & 6.8 & 32.5 & 11.8 & 8.5 & 73.9 \\
\hline $\mathrm{Ti}$ & 0.9 & 1.8 & 0.4 & 2.7 & 2.1 & 0.2 & 0.8 & 1.8 & 2.6 & 0.4 & 0.6 & 0.2 & 0.1 \\
\hline $\mathrm{Fe}$ & 3.2 & 9.3 & 26.7 & 6.2 & 8.4 & 0.7 & 6.6 & 13.2 & 66.2 & 3.3 & 19.8 & 30.1 & 0.0 \\
\hline $\mathrm{Mn}$ & 0.0 & 0.0 & 0.0 & 0.0 & 0.2 & 0.0 & 0.1 & 0.1 & 0.4 & 0.1 & 0.2 & 0.4 & 0.1 \\
\hline $\mathrm{Ni}$ & 0.1 & 0.0 & 2.5 & 0.5 & 0.2 & 0.0 & 0.0 & 0.4 & 0.4 & 0.0 & 0.3 & 0.7 & 0.0 \\
\hline $\mathrm{V}$ & 1.7 & 1.2 & 0.5 & 0.7 & 2.7 & 0.0 & 2.3 & 1.9 & 0.2 & 0.4 & 0.0 & 0.0 & 0.2 \\
\hline Total & 100.0 & 100.1 & 100.1 & 100.1 & 100.1 & 100.0 & 100.2 & 100.1 & 100.0 & 100.0 & 100.0 & 100.0 & 100.0 \\
\hline
\end{tabular}




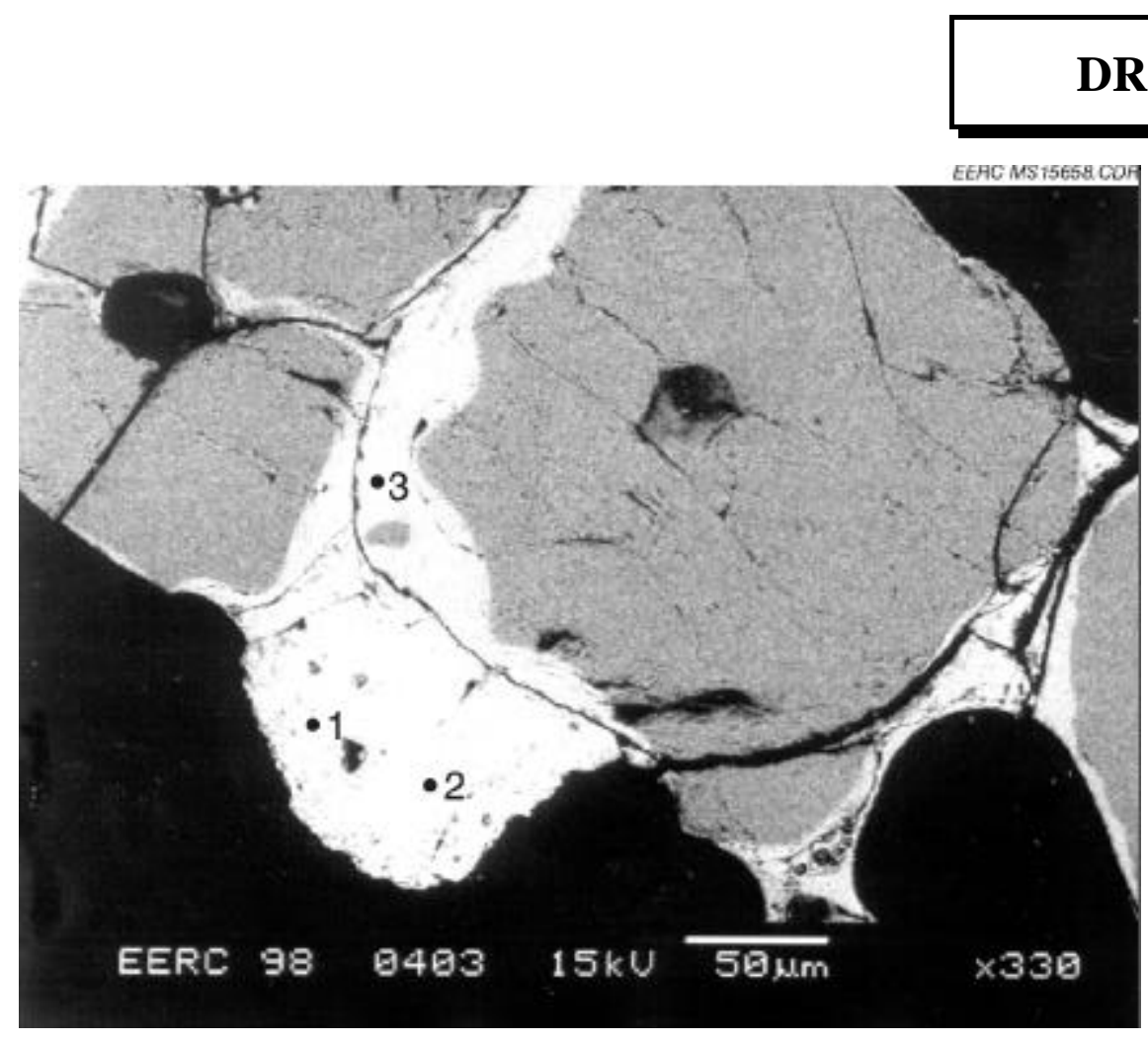

Figure 15. SEM micrograph of standpipe deposit from gasification test of Wyodak coal.

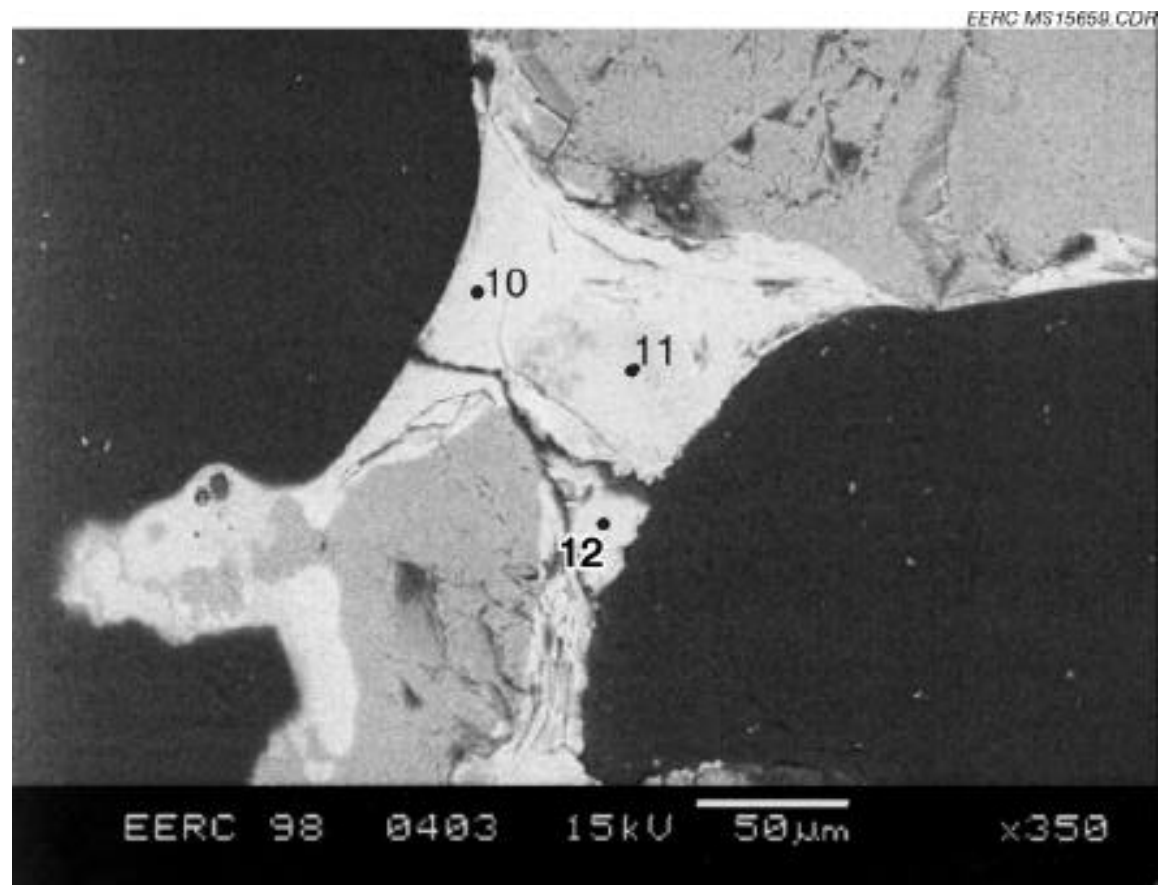

Figure 16. SEM micrograph of standpipe deposit from gasification test of Wyodak coal. 


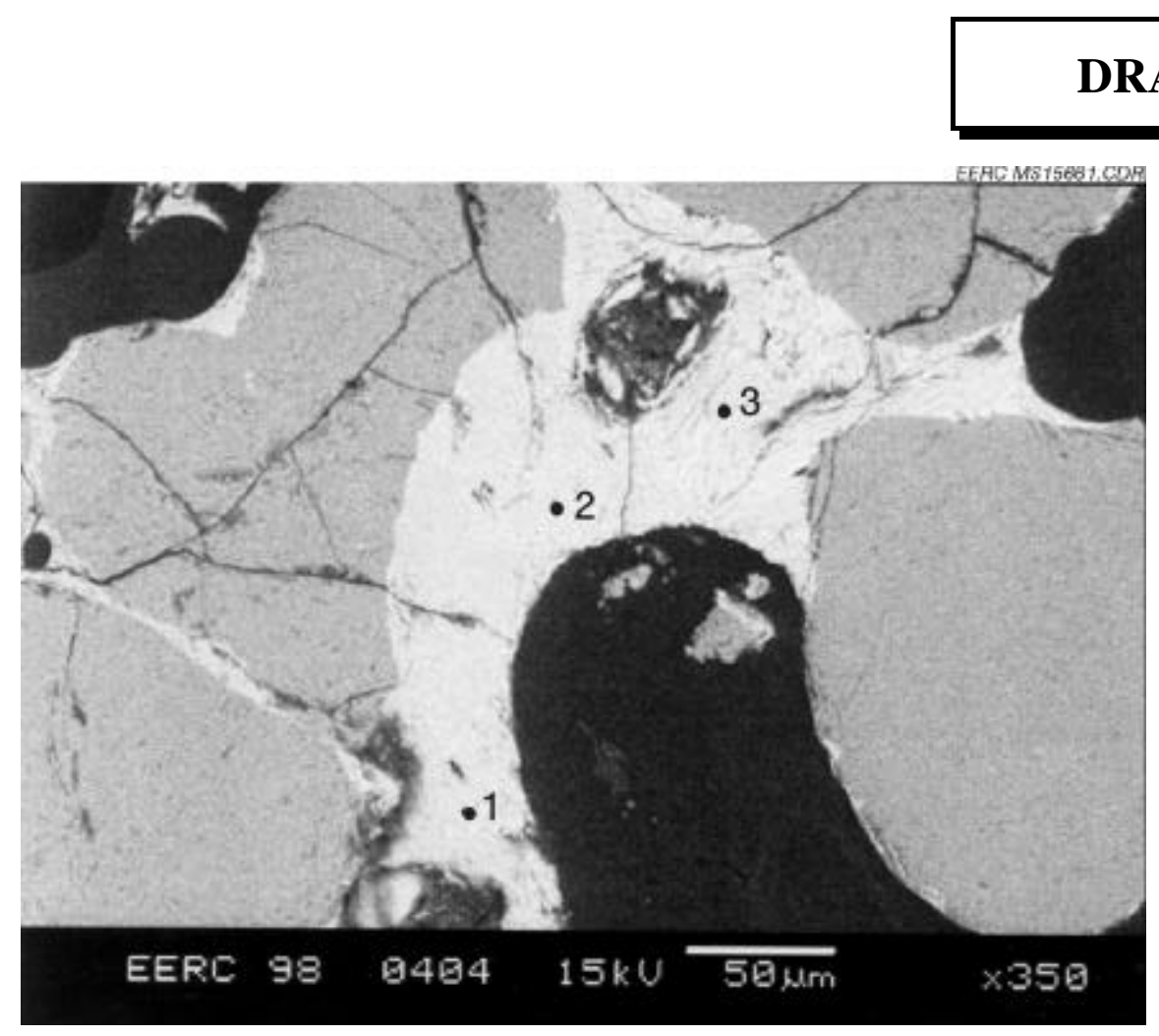

Figure 17. SEM micrograph of mixing zone deposit from gasification test on Wyodak coal.

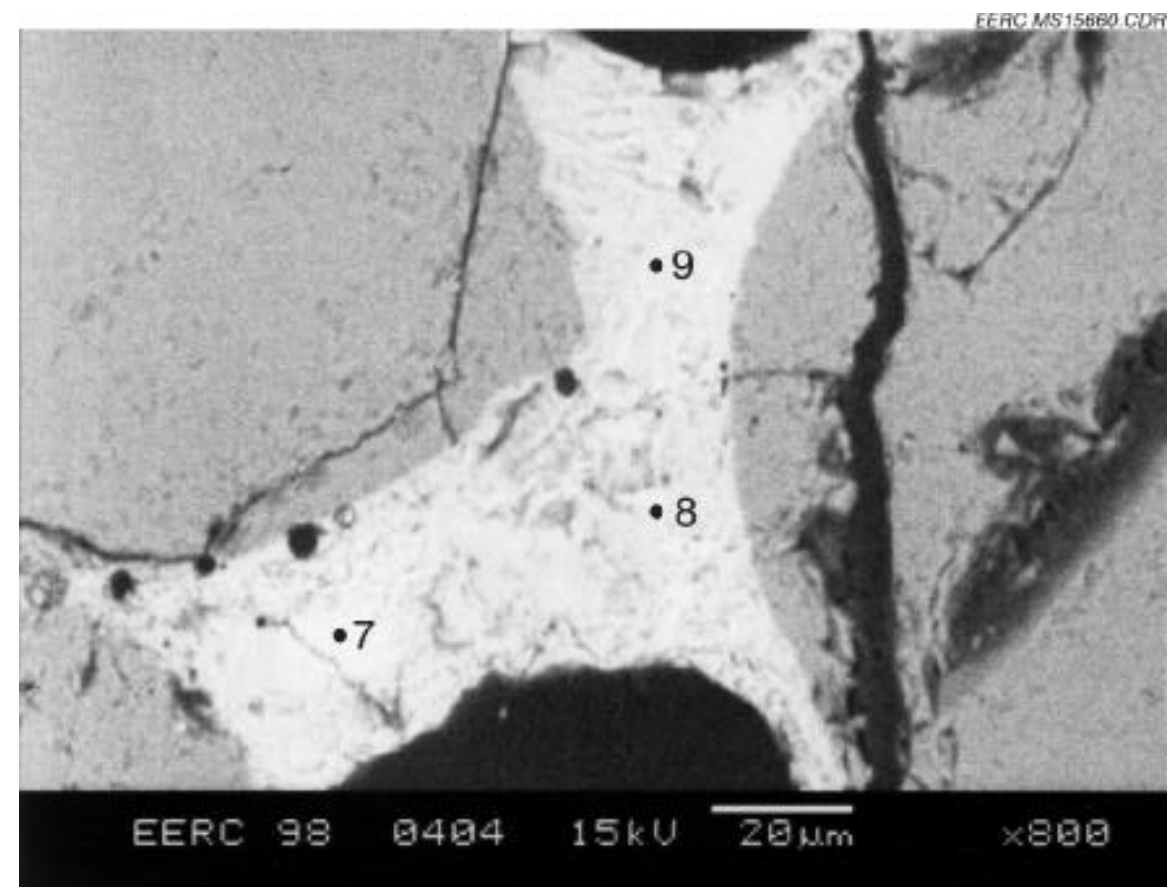

Figure 18. SEM micrograph of mixing zone deposit from gasification test of Wyodak coal. 


\section{DRAFT}

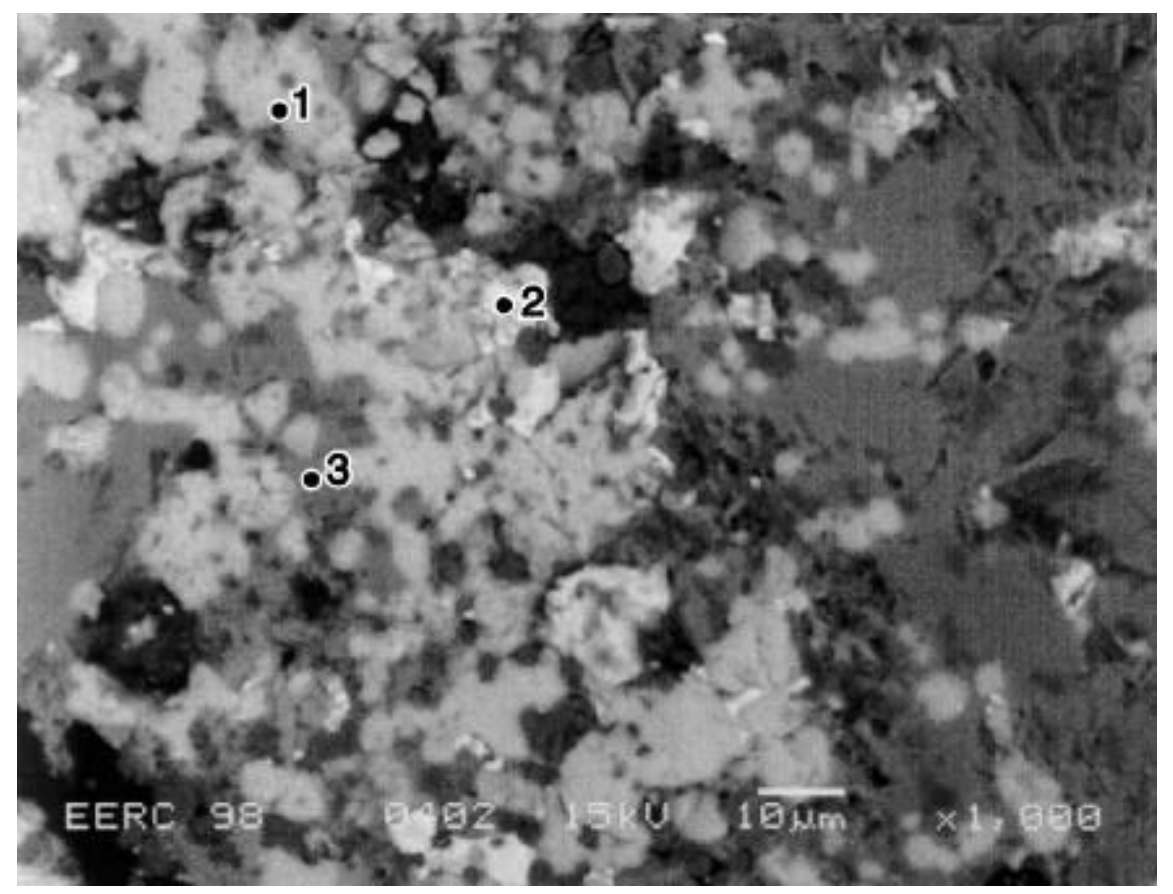

Figure 19. SEM micrograph of mixing zone deposit from gasification test of Illinois No. 6 coal.

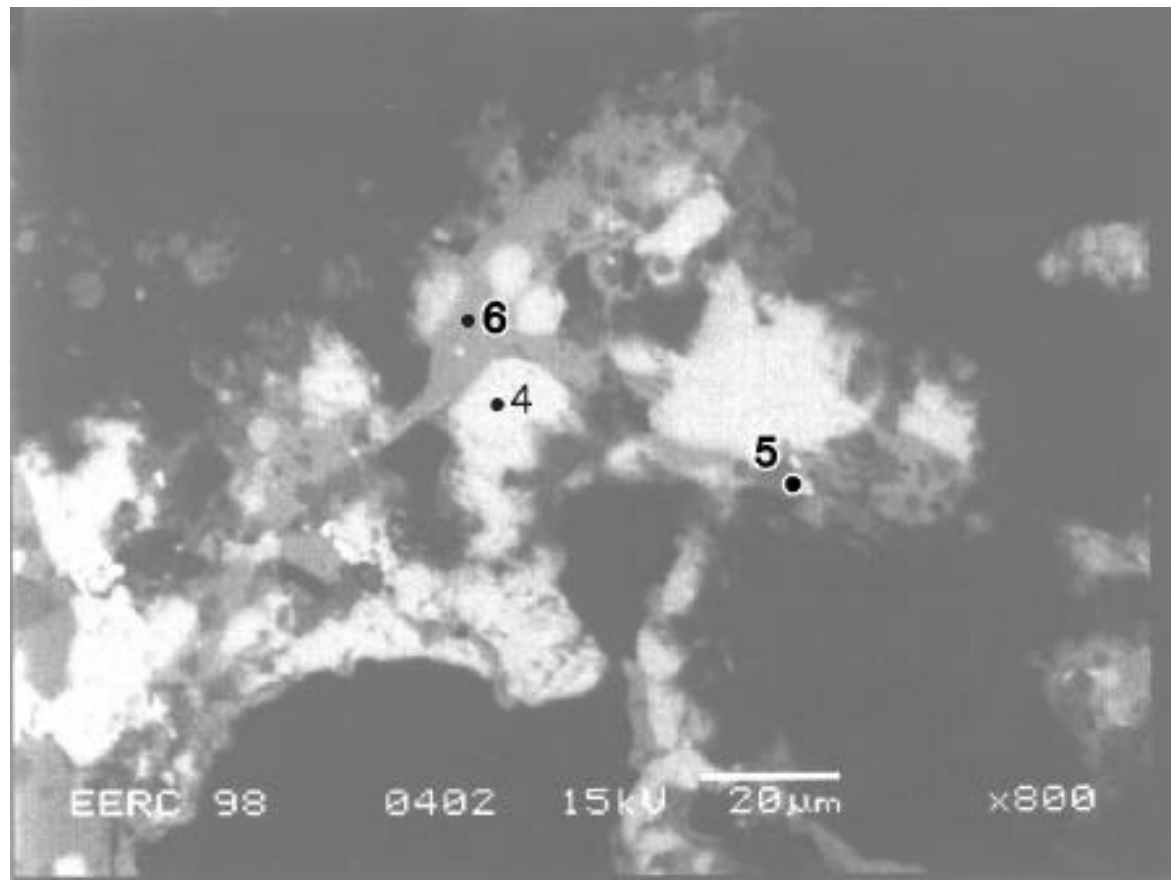

Figure 20. SEM micrograph of mixing zone deposit from gasification test of Illinois No. 6 coal. 


\section{DRAFT}

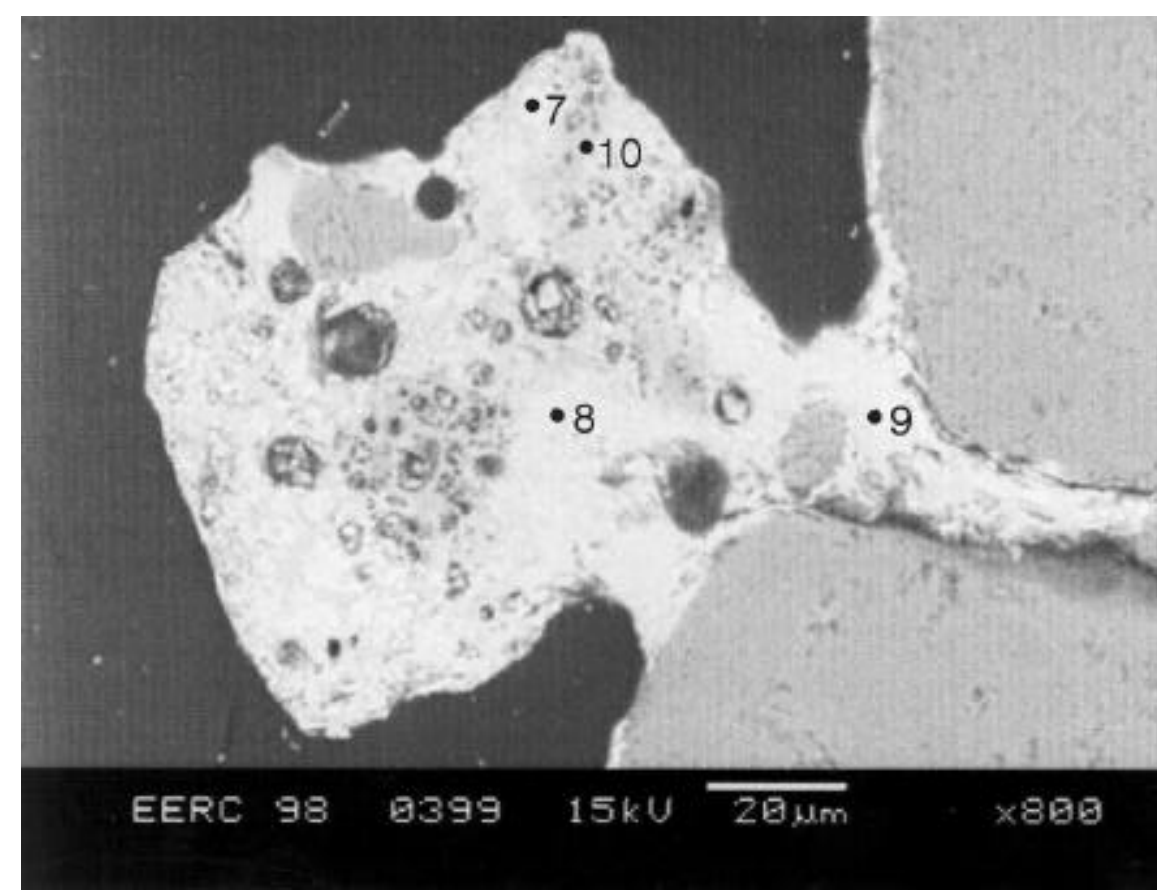

Figure 21. SEM micrograph of standpipe deposit material from the combustion test of Tuscaloosa Petcoke.

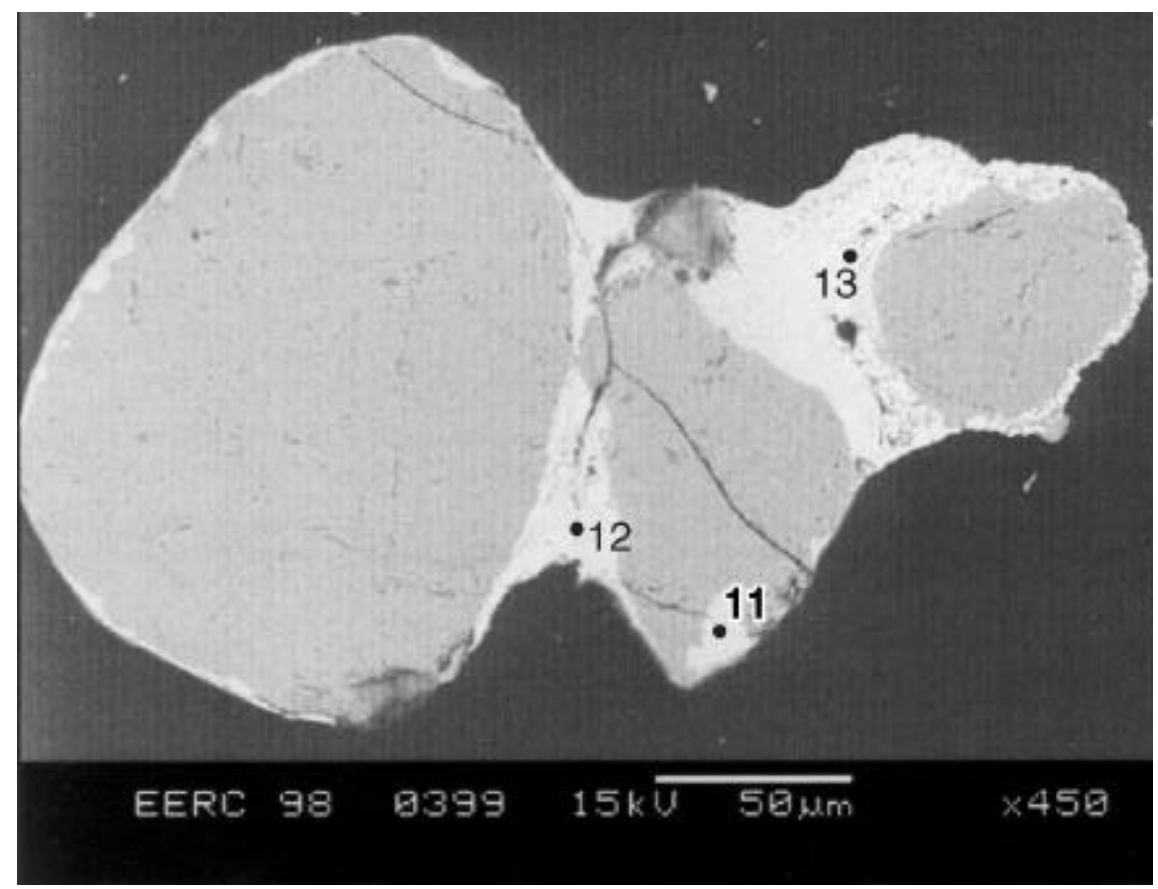

Figure 22. SEM micrograph of standpipe deposit material from the combustion test of Tuscaloosa Petcoke. 


\section{DRAFT}

\subsubsection{Testing Conditions}

Alloy RA25MA was received as a plate and the other three alloys as thick-walled tubes. Incoloy 800HT, HR3C, and TP347HFG tubes were cross-sectioned and cut into quarter sections. Coupons were cut from these alloys and ground to a flat surface with 800 grit paper. Table 25 shows the compositions of the four alloys and their test parameters. The coupons were arranged in samples sets composed of two coupons of each alloy. One was tested without slag, and the other coupon was covered with a layer of potassium sulfate and a layer of Illinois No. 6 slag. The samples were oxidized in oxygen for 100 hours at $625^{\circ} \mathrm{C}$ before testing.

The coupons were heated in a ceramic tube furnace to $625^{\circ} \mathrm{C}$ in the presence of a synthetic combustion gas whose average composition was $14 \%$ carbon dioxide, $4 \%$ oxygen, $1000 \mathrm{ppm}$ sulfur dioxide, and the balance nitrogen. The ceramic tube was modified to be pressure-sensitive for only slightly above atmospheric pressure in order to isolate reaction or combustion gases from furnace elements. Sample sets were removed at $100^{\circ}, 600^{\circ}, 900^{\circ}$, and $1178^{\circ} \mathrm{C}$. The coupons were cross-sectioned and examined by SEM.

\subsubsection{Results}

RA253MA showed little reaction to the synthetic combustion gas. Spalling did occur throughout the length in localized areas. Localized areas of iron oxide-rich scale were also detected but further chemical changes were not. The expected chromium oxide scale layer was not detected. Large changes could be detected in the samples with slag and potassium sulfate. After only 100 hours, sulfide penetration as deep as 5 microns ( 0.2 mil) was observed. At the end of the test, sulfur penetration was detected as deep as 40 microns (1.6 mil). The sulfides detected were iron- and nickel-rich.

TABLE 25

Alloy Testing Materials

\begin{tabular}{lccccccc}
\hline Alloy, wt $\%$ & $\mathrm{Cr}$ & $\mathrm{Ni}$ & $\mathrm{Nb}$ & Other & $\begin{array}{c}\text { Average Coupon } \\
\text { Surface Area, } \mathrm{cm}^{2}\end{array}$ & $\begin{array}{c}\text { Amount of } \\
\mathrm{K}_{2} \mathrm{SO}_{4}, \mathrm{~g}\end{array}$ & $\begin{array}{c}\text { Amount of Ill. } \\
\text { No. 6 Slag, g }\end{array}$ \\
\hline RA253MA & 21 & 11 & & $\begin{array}{c}\mathrm{C}, \mathrm{Si}, \mathrm{Mn}, \mathrm{P}, \mathrm{S}, \mathrm{N}, \\
\mathrm{Ce}, \mathrm{Sn}, \mathrm{Cu}\end{array}$ & 6.25 & 0.128 & 1.249 \\
Incoloy 800HT & 21 & 32.5 & & $\mathrm{Cu}, \mathrm{Al}, \mathrm{Si}, \mathrm{Ti}$ & 6.49 & 0.129 & 0.966 \\
HR3C & 25 & 20 & 0.4 & $\mathrm{~N}, \mathrm{P}, \mathrm{Si}, \mathrm{Mn}$ & 3.43 & 0.050 & 0.726 \\
TP347HFG & 18 & 10 & 1.0 & $\mathrm{Al}, \mathrm{Si}, \mathrm{Mn}, \mathrm{Cu}, \mathrm{P}$ & 3.16 & 0.051 & 0.667 \\
\hline
\end{tabular}

Localized areas of spalling were also detected with the Incoloy 800HT alloy. Iron oxiderich scale in localized areas was observed at the sample surface of coupons tested in combustion gas only. No measurable compositional changes in these coupons could be detected in samples tested below 900 hours. Above 900 hours, localized areas of oxide penetration could be measured 
as deep as 3 microns $(0.1$ mil) from the exposed surface. The oxide contained mostly chromium with some iron and nickel. Incoloy coupons, tested longer than 600 hours, with potassium sulfate and slag added, showed penetration of large amounts of oxide with sulfate and/or sulfide compounds rich in iron and nickel. Some areas showed penetration deeper than 100 microns (3.9 mils). The penetration tended to be more uniform with increasing time.

A chromium iron oxide layer could be detected with Alloy HR3C. Combustion gas had a much larger effect on these coupons. With increasing time, the oxide layer became as thick as 2 microns $(0.1 \mathrm{mil})$ and began to form a highly irregular interface with the raw alloy. This caused pits in some areas with no oxide surface as deep as 6 microns $(0.2 \mathrm{mil})$. With coupons covered with potassium sulfide and slag, sulfide compounds were not formed but rather iron and chromium oxides. Sulfur appeared to have no effect on the alloy. Corrosive attack of the alloy was minimal, and maximum penetration of oxides was only 5 microns ( $0.2 \mathrm{mil})$. Most of the niobium in the alloy was found to be concentrated in small spherical "nodules" rather than evenly dispersed throughout the alloy. It is unclear what effect this has on the alloy's corrosive resistance.

Alloy $347 \mathrm{HFG}$ shows the formation of a thin iron oxide layer with some chromium. Much like Alloy HR3C, combustion gas had a great effect on the corrosion of the coupon's surface. With the increase in time, the iron oxide layer increased in thickness. Some areas of the layer were as thick as 5 microns ( 0.2 mil). Sulfur compounds did affect the coupon's corrosion resistance, but oxides played the greater role. Niobium in the sample also was similar to that of Alloy HR3C. The concentrated nodules near the surface of the coupon were more susceptible to oxidation than the surrounding alloy. This created networks of oxidized channels which loosened zones of lowniobium alloy and allowed them break away from the coupon. The resulting pitting and irregular surface varied as much as 25 microns (1 mil).

\subsection{CONCLUSIONS}

In conclusion, great strides were made in understanding key issues in ash behavior for advanced power systems. With respect to a review of the current status of ash behavior research it was found that quantitative mechanisms for predicting ash behavior are still lacking, especially for application in predictive algorithms. It was also learned that mechanisms for predicting ash behavior for nontraditional fuels such as biomass and wastes materials are lacking. With respect to specific mechanisms of ash behavior, it is very apparent from current literature that more research is needed to understand deposit emissivity, conductivity, and reflectivity properties. Thermal conductivity and emissivity remain the most difficult ash properties to model. U.S. and world emphasis on fossil fuel efficiency and global warming issues make research on developing advanced, highly efficient power systems and associated ash behavior issues the highest research priority.

Initial pilot experiments performed using heated-stage XRD were performed in order to establish more concrete phase identification during slag melt cooling. The information is very important for understanding viscosity-temperature-composition relationships for silicate systems characteristic of coal combustion and gasification. Modeling of ash viscosity based on 
composition and temperature would be advanced by establishing the temperature critical viscosity and specific crystallization pathways. Only one of six slags tested using a heated-stage x-ray diffractometer at Oak Ridge National Laboratory, a Rochelle slag, showed any discernable crystallization phase formation during testing. The heated XRD method was never perfected, and more testing will be needed to make this method useful. A new heated-stage XRD system has been added to the diffractometer at the EERC, and future tests will be planned.

HSM was used successfully to describe in situ mechanisms of ash sintering and to calculate the viscosity of model ash and coal ash particles. The technique proved to be valuable for measuring viscosities for soda-lime glass and Illinois No. 6 fly ash at temperatures from $670^{\circ}-930^{\circ} \mathrm{C}$. Comparison of the HSM technique to four existing viscosity models showed results that were all within an order of magnitude of each other; however, without further corroborating viscosity measurements, it will be difficult to select a model that best predicts viscosity and sintering behavior.

Factors that affect the TRDU product gas quality appear to be circulation rate, coal type, temperature, and air:coal and steam:coal ratios. A decrease in circulation rate improves the product gas quality by increasing the solids residence time in the gasification zones of the TRDU; however, lower circulation rate tests are more prone to deposition and agglomeration problems as a result of inadequate gas-solid mixing in the mixing zone. The less reactive bituminous fuels were gasified at higher temperatures to produce a product gas quality similar to those obtained with the Wyodak fuel. Higher operating temperatures increase carbon conversion for the TRDU but again at the risk of increased ash deposition. Higher steam/coal ratios result in improved product gas quality with increased hydrogen and carbon dioxide formation from the water-gas shift reaction, but data also show additional $\mathrm{CO}$ was produced via the steam-carbon reaction. Higher air/coal ratios gave lower product gas quality, especially at ratios above 3.5, with generally under 3.0 providing the best product gas.

The use of a nitrogen purge as a type of sootblower kept deposits from forming in an area of relatively low temperature $\left(825^{\circ}\right.$ to $\left.875^{\circ} \mathrm{C}\right)$ at the transition from the vertical riser to the horizontal inlet of the disengager cyclone, an area where the gas and solid flow make a $90^{\circ}$ turn. Deposits would form in this region after shutting the purge down. The deposits were white in color on the inside edge where they were exposed to air during shutdown, while the outside edge was black in color due to the carbon contained in the deposit which did not get exposed to air during the shutdown. A comparison of the glue chemistry with that of the bulk samples from the TRDU indicates that the glue is enriched in the smallest ash particles, particularly the high concentration of organically associated calcium which should form very fine aerosols. There did not appear to be any appreciable sulfur in either the white oxidized layer or the black carbonaceous layer of the deposits, perhaps suggesting that the formation of a sticky calcium sulfide is not a major mechanism for the deposit formation. For the Wyodak coal the presence of very small mineral particles, especially high concentrations of kaolinite $\left(\mathrm{Al}_{4} \mathrm{Si}_{4} \mathrm{O}_{10}[\mathrm{OH}]_{8}\right)$ and the fact that the organically associated calcium will form vapor or very fine aerosols can lead to the formation of lower-melting aluminosilicates such as calcium aluminosilicates and montmorillonite $\left([0.5 \mathrm{Ca}, \mathrm{Na}]_{0.7}[\mathrm{Al}, \mathrm{Mg}, \mathrm{Fe}]_{4}[\mathrm{Si}, \mathrm{Al}]_{8} \mathrm{O}_{20}\right)$. Previous tests using this same coal showed significant increases in calcium aluminosilicates and montmorillonite in the hot-gas filter ash (i.e., the smallest particle sizes), suggesting the formation of these compounds under the operating conditions of the TRDU. These data suggest that the "glue" appears to be a calcium aluminosilicate that was possibly the 


\section{DRAFT}

result of vapor-phase calcium from the organically associated calcium in the coal reacting directly with the fine coal/ash to form a low-melting eutectic coating on the bed material and dolomite particles.

For Illinois No. 6 coal, a dark-colored semispherical agglomerate was recovered from the bed material. The chemical composition toward the inside edge of these deposits was substantially higher in iron than the outer edge (which probably started forming using the low- iron Wyodak coal) and previous deposits obtained from the TRDU. The glue appears to be a high $\mathrm{Fe}-\mathrm{Ca}$ silicate, while the white spots are an iron spinel which possibly precipitated from the amorphous glue. Calcium and iron sulfides were also found in the Illinois No. 6 burner deposits. For the deposits from the Wyodak or SUFCo coals, the layers around or fill material between the bed material particles is predominantly calcium silicate material with lesser amounts of iron, magnesium, alumina, and low levels of sodium in the case of the SUFCo deposits.

With respect to corrosion, Alloy RA253MA showed little reaction to the synthetic combustion gas. Spalling did occur throughout the length in localized areas where iron oxide-rich scales were formed. The expected chromium oxide scale layer was not detected. Large changes could be detected in the samples using slag and potassium sulfate layers. After only 100 hours, significant sulfide penetration was observed, and by the end of the test, iron and nickel sulfide penetration was detected as deep as 40 microns (1.6 mil).

Localized areas of spalling were also detected with the Incoloy 800HT alloy. Iron oxiderich scaling in localized areas was observed at the sample surface of coupons tested in combustion gas only. No measurable compositional changes in these coupons could be detected in samples tested below 900 hours. Above 900 hours, localized areas of oxide penetration could be measured as deep as 3 microns $(0.1$ mil) from the exposed surface. The oxide contained mostly chromium with some iron and nickel. Incoloy coupons, tested longer than 600 hours, with potassium sulfate and slag added, showed penetration of large amounts of oxide, with sulfate and/or sulfide compounds rich in iron and nickel. Some areas showed penetration deeper than 100 microns (3.9 mils). The penetration tended to be more uniform with increasing time.

A chromium iron oxide layer could be detected with Alloy HR3C. Combustion gas had a much greater effect on these coupons. With increasing time, the oxide layer became as thick as 2 microns $(0.1 \mathrm{mil})$ and began to form a highly irregular interface with the raw alloy. With coupons covered with potassium sulfide and slag, sulfide compounds were not formed but rather iron and chromium oxides. Sulfur appeared to have no effect on the alloy. Corrosive attack of the alloy was minimal, and maximum penetration of oxides was only 5 microns ( 0.2 mil). Most of the niobium in the alloy was found to be concentrated in small spherical "nodules" rather than evenly dispersed throughout the alloy. It is unclear what effect this has on the alloy's corrosive resistance.

Alloy 347HFG showed the formation of a thin iron oxide layer with some chromium. Much like Alloy HR3C, combustion gas had a great effect on the corrosion of the coupon's surface. With the increase in time, the iron oxide layer increased in thickness. Some areas of the layer were as thick as 5 microns ( 0.2 mil). Sulfur compounds did affect the coupon's corrosion resistance, but oxides played the greater role. Niobium in the sample also was similar to that of Alloy HR3C. 


\section{DRAFT}

The concentrated nodules near the surface of the coupon were more susceptible to oxidation than the surrounding alloy. This created networks of oxidized channels which loosened zones of lowniobium alloy and allowed them break away from the coupon. The resulting pitting and irregular surface varied as much as 25 microns (1 mil).

\subsection{REFERENCES}

1. Raask, E. Mineral Impurities in Coal Combustion - Behavior, Problems, and Remedial Measures; Hemisphere Publishing Corporation: Washington, 1985; pp 137-140.

2. Bellehumeur, C.T.; Bisaria, M.K.; Vlachopoulos, J. “An Experimental Study and Model Assessment of Polymer Sintering," Polymer Engineering and Science 1996, 36 (17), 2198-2207.

3. Hopper, R.W. "Coalescence of Two Equal Cylinders: Exact Results for Creeping Viscous Plane Flow Driven by Capillarity," Communications of the American Ceramic Society 1984, 67, 262-264.

4. Pokluda, O.; Bellehumeur, C.T.; Vlachopoulos, J. "Modification of Frenkel's Model for Sintering," AIChE Journal 1997, 43 (12), 3253-3256.

5. Bansal, N.P.; Doremus, R.H. Handbook of Glass Properties; Academic Press: New York, 1986; p 103.

6. Kalmanovitch, D.P.; Frank, M. “An Effective Model of Viscosity for Ash Deposition Phenomena," In Proceedings of Mineral Matter and Ash Deposition from Coal; Bryers, R.W.; Vorres, K.S., Eds.; Engineering Foundation, Santa Barbara, CA, Feb. 22-26, 1988; pp 89-101.

7. Srinivasachar, S.; Helble, J.J.; Boni, A.A. "Mineral Behavior During Coal Combustion 1. Pyrite Transformations," Prog. Energy Combust. Sci. 1990, 16, 281-292.

8. Benson, S.A.; Sondreal, E.A. "Impact of Low-Rank Coal Properties on Advanced Power Systems," in Proceedings of 13th Annual Pittsburgh Coal Conference; Chiang, S.-H., Ed.; 1996; Vol. 1, pp 484-498.

9. Groen, J.C.; Craig, J.R. "The Inorganic Geochemistry of Coal, Petroleum, and their Gasification/Combustion Products." Fuel Process Technol. 1994, 40, pp 15-48. 


\title{
DRAFT
}

\section{PRELIMINARY SUMMARY OF KEY ISSUES IN ASH BEHAVIOR}

\author{
ISSUE: COAL GRINDABILITY \\ EERC Expertise (0-5): 4 \\ Research Priority (0-5): 2
}

\begin{abstract}
Summary
Prediction of grindability of coal and coal blends is a useful although not a high-priority focus area. Blending of coals generally results in the concentration of the harder material in larger size fractions and softer material in the finer size fractions, affecting the distribution of ash and volatile matter. Moisture has a profound effect on the grindability and handling properties of western subbituminous coals and is not well modeled. Other factors, in particular the effect of moisture on mill temperature and throughput, often are of more significance in fuel switching than grindability.

\section{Research Questions}

- Quantitative relationship of moisture to grindability of western coals

- Effect of hard-soft coal blends on ash distribution in coal fractions

- Inclusion of mill capacity as a function of moisture into performance indices
\end{abstract}

\section{Applicable EERC Research \\ Development of Fireside Performance Indices}

A relationship was found relating sulfur and moisture content to the Hardgrove grindability of 11 western subbituminous coals. The Hardgrove grindability index (HGI) values and properties for eleven coals were examined. Selected mineral abundances and the degree of mineral- maceral association, represented by the ratio of included to excluded minerals, for six of the test coals (Antelope, Big Sky, Black Thunder, Caballo Rojo, Rochelle, and Spring Creek [MNPL]) were also examined as possible predictors of grindability. A correlation analysis was performed to identify the coal properties that are most significantly related to the HGI; correlation coefficients with absolute values of $\geq 0.7$ were considered significant. The coal moisture contents showed some degree of correlation to the HGI, even though the range in moisture content represented by most of the coals was limited. For example, the moisture contents for seven of the coals (Antelope, Big Sky, Black Thunder, Caballo Rojo, Dietz, Rochelle, and Spring Creek) range from only $21 \%$ to $25 \%$, yet the HGI values range from 39 to 53, indicating that other factors are involved in the HGI variation. Grindability correlates best to the total sulfur and ash contents of the coals. The correlation of ash with HGI improves greatly (coefficient increases to 0.866 ) when the Wyodak coal is excluded from the linear regression analysis. The maceral and mineral abundances and included-excluded mineral ratio are insignificantly correlated to coal grindability. An equation for predicting the HGI of subbituminous coals was derived from a multiple regression analysis of the ash and total sulfur variables; the predicted values compared favorably to the analytically determined HGI values. The regression equation was incorporated into the PCQUEST computer program to calculate a grindability index. Application of the index should be restricted to comparing the grindabilities of subbituminous coals that have similar moisture contents to those used in this study, i.e., 21 to $33 \mathrm{wt} \%$ on an as-received basis. 


\section{DRAFT}

\section{Technology Assessment for Blending Western and Eastern Coals for $\mathrm{SO}_{2}$ Compliance}

An assessment of mill performance primarily related to mill capacity and temperature limitations. Grindability was not called out as an issue.

\section{Pilot Plant Assessment of Blend Properties}

A series of tests were performed to determine the effects of blending eastern bituminous coals with western subbituminous coals on utility boiler operation. Mill performance tests were performed by CONSOL, Inc., at its facility in Library, PA. Mill performance tests indicated that at design pulverizer conditions (relative to pulverization of bituminous coal), the decreased thermal input of the subbituminous coals resulted in derates on the mill of up to $55 \%$ of the maximum thermal input of the bituminous coals. One Pittsburgh seam bituminous coal, one Illinois No. 6 seam bituminous coal, and two Powder River Basin (PRB) subbituminous coals were tested. By raising the mill outlet temperature between $5^{\circ}$ and $25^{\circ} \mathrm{F}$, thermal throughput for the subbituminous coals could be increased by $10 \%$ to $20 \%$. Increasing the air/fuel ratio also tended to increase thermal throughput, but at the expense of a coarser product. At the maximum thermal throughput for the subbituminous coals and at the highest air/fuel ratio, product fineness (less than 200 mesh) decreased by up to 15 percentage points. Interestingly, the lowest heat content subbituminous coal exhibited the lowest thermal derate of the two PRB coals tested, but required much higher mill energy input.

\section{Fuel Quality Advisor}

The coal handleability model rates the dust handling for coal by making a correlation between type of coal, particle size distribution, and moisture content. Early attempts were made to use maceral content to help group the various lignite, subbituminous, and bituminous coals. However, maceral data were inconclusive and varied dramatically within each region. The as-received moisture content relative to the coal's original bed moisture content was the main factor in determining the overall coal handleability indices. A slacking index was used to further enhance the indices. The slacking index was based upon information compiled by the Bureau of Mines for various ranks of coal.

\section{Validation of Fireside Performance Indices - Fouling Assessment of Coal and Soil-Waste Blends}

The PCQUEST predicted grindability corresponds to the Hardgrove grindability and was developed for Western subbituminous coals. The predicted Hardgrove grindability of five Eastern bituminous coals and the expected grindability based on experience were compared. Also included was a calculated Hardgrove grindability based on a formula developed by Gomez and Hazen based on 735 coal samples. The PCQUEST grindability index significantly underestimates the Hardgrove grindability, while the formula of Gomez and Hazen significantly overestimates it. It is to be noted that with the exception of one coal, the Gomez and Hazen formula produces values which bear a linear relation to the expected Hardgrove values. Both predictive methods perform very poorly when compared to the expected values. Significant further improvement was seen to be needed in the PCQUEST grindability algorithms to allow them to accommodate bituminous coals. 


\section{DRAFT}

\section{Key Literature}

Zygarlicke, C.J.; Galbreath, K.C.; McCollor, D.L. "Development of Fireside Performance Indices," final topical report for U.S. DOE DE-FC21-93MC30098; EERC publication, Nov. 1995.

Gunderson, J.R.; Moe, T.A.; Selle, S.J.; Harding, N.S. “Technology Assessment for Blending Western and Eastern Coals for $\mathrm{SO}_{2}$ Compliance,” EPRI Final Report TR-105748; May 1996.

Gunderson, J.R.; Moe, T.A.; Abbott, M.; Douglas, B.; Selle, S.J. "Pilot Plant Assessment of Blend Properties," final report; Oct. 1996.

Allan, S.E; Anderson, C.M.; Erickson, T.E.; Jensen, R.R.; McCollor, D.P.; Zygarlicke, C.J. "Fuel Quality Advisor," final report for the period Jan. 1, 1995 - Sept. 30, 1996 U.S. DOE DE-FC2193MC30097; Nov. 1996.

Zygarlicke, C.J.; McCollor, D.P. "Fouling Assessment of Coal and Soil-Waste Blends," final report for Duke Power Company, March 1996.

Vecci, S.J.; Moore, G.F. “Determine Coal Grindability,” Power 1978, March, 74.

The article is a discussion of industry approaches to obtaining reliable Hardgrove grindability indices for western coals. One method is to obtain grindability indices at a range of moisture levels from as received to the ASTM air-dried levels. A second standard continuous grindability index has also been developed.

Gomez, M.; Hazen, K. "Prediction of Coal Grindability from Exploration Data," U.S. Bureau of Mines Report of Investigations R1, 7421, 1970.

A general prediction model for the Hardgrove grindability index was constructed for 735 coal samples using the proximate analysis, heating value, and sulfur content. The coals used to develop the general index ranged in volatile matter from 12.8 to 49.2 percent, dry basis, and had grindability indexes ranging from 35 to 121 . A restricted model applicable to bituminous coals having grindabilities in the 40 to 110 range was developed from the proximate analysis and the petrographic composition of the coal. The prediction of coal grindability within a seam was also investigated. The results support the belief that mechanical properties of the coal are related to both chemical and petrographic factors of the coal.

Cho, H.; Luckie, P.T. “Grinding Behavior of Coal in a Standard Ball-and-Race Mill,” Energy Fuels 1995, 59-66.

An investigation was carried out to predict size-composition makeup of the product of a coal blend ground in a ball-and-race mill using the breakage characteristics of the individual components. The composition of the product size intervals is generally different from the weighted sum of the two products from separate grinding. An empirical equation was used to predict the change in breakage parameters as a function of the blending ratio and the difference between the relative strengths of the two materials. A locked-cycle simulation for grinding a binary mixture shows that the content of the mill charge becomes richer in the stronger component. The system attains steady state when the absolute production rates of 


\section{DRAFT}

both materials are the same, although the ratio of materials in the mill charge is not necessarily the same as the ratio in the feed. As a result, the production rate can be lower than expected based on the feed ratio.

CQ Inc. "Development of a Coal Blending Model," final report for ESEERCO; Aug. 1994. This project developed models for engineers to use in calculating blend properties for coal blends and also investigated blending volatile matter. It was found that the HGI for a blend can be approximated by a weighted average of the parent coal HGI values. However, this blended HGI may not be the most important property related to grindability for a coal blend. The hardest coals are concentrated in the coarsest fractions of the pulverized blend, while the softest coals are concentrated in the finest fractions. This segregation causes variations in the volatile matter, sulfur, ash composition, and ash fusion temperature by size and can affect performance in the boiler. This segregation is masked by evaluating only the composite values for these properties.

Dougan, D.R.; Peters, G.W. "MPS Pulverizer Operating and Maintenance Experience on Texas Lignites," Gulf Coast Lignite Conference Proceedings; Chas. T. Main, Inc.: Houston, TX, 1984; pp 123-133.

Pulverizer operating experience on Texas lignites indicates that problems of erosion and corrosion unique to lignite have been resolved by ceramic linings and dipped coating on critical metal parts, such as springs. A test for "apparent grindability" is performed on 1-ton samples in a MPS-32 pulverizer to obtain a reliable relationship between feed rate, fineness, and power. Differences between these results and the Hardgrove grindability index are attributed to coal moisture.

Duzy, A.F. "American Coal Characteristics and Their Effects on the Design of Steam Generating Units," ASME Annual Meeting, Atlantic City, NJ; No. 59-A242, Nov. 1959; 8 p.

Rank, volatile matter (VM), Btu, and ash importantly affect boiler design. Property/effect relationships for pulverizers include Btu/amount, grindability/capacity, moisture/drying, VM/air temperature, ash-sulfur/abrasion. Suitability for cyclone firing is determined by VM and slag viscosity; pc-firing by VM, and fineness. Heat release and furnace exit gas temperature must be matched with ash properties. Wide tube spacings are required above $0.4 \% \mathrm{Na}_{2} \mathrm{O}$ in dry coal. Corrosion is related to coal $\mathrm{Na}, \mathrm{K}, \mathrm{S}$, and $\mathrm{Cl}$.

Ellman, R.C.; Belter, J.W.; Dockter, L. "Lignite Pulverization: A Status Report," in Technology and Use of Lignite; IC 8376; U.S. Bureau of Mines: 1968; pp 29-39.

Pilot- and commercial-scale grindability studies indicated variations in pulverization within and between seams. In-mill drying increased pulverizer capacity and reduced power requirements. Data are presented on Hardgrove Index versus coal moisture and petrographic constituents. 


\section{DRAFT}

Luckie, P.T.; Austin, L.G. Coal Grinding Technology; U.S. DOE FE-2475-25; 1980; 92 p. This report is a source of data on the Hardgrove grindability of U.S. coals, including subbituminous coals from Colorado, New Mexico, Utah, and Wyoming. It reviews the fundamental physics of coal fracturing, the selection and sizing of equipment, operating characteristics, and costs.

Piepho, R.R. "Handling and Pulverizing Lignite at Monticello," Gulf Coast Lignite Conference Proceedings; Chas. T. Main, Inc.: Houston, TX, 1980; pp 155-166.

Handling and pulverization problems and their solutions are presented, based on experience at the Monticello plant burning a Texas lignite containing 22\% ash (dry basis). Grindability tests are run by a continuous feed method using a MPS-32 laboratory mill to augment the batch test data on Hardgrove grindability index, which is strongly influenced by coal moisture. Causes for fluctuations in the flow of lignite from the bunkers to the mills are discussed.

Piepho, R.R.; Dougan, D.R. "Grindability Measurements on Low-Rank Fuels," Coal Technology '81; 1981; Vol. 3, pp 111-121; 4 ${ }^{\text {th }}$ International Coal Utilization Exhibition \& Conference, Houston, TX, Nov. 1981.

The results of laboratory grindability tests are related to full-scale experience, with emphasis on low-rank U.S. coals. The relationship between grindability and moisture content for lowrank coals is discussed.

Thiede, R.L.; Rogers, W.C. "Using High-Moisture Western Coals in Power Boilers Designed for Pulverized Bituminous Coal Firing," Proceedings of the American Power Conference; 1975; Vol. 37, pp 393-400.

A 4-day test substituting a low-alkali Wyoming subbituminous coal $\left(1.5 \% \mathrm{Na}_{2} \mathrm{O}+\mathrm{K}_{2} \mathrm{O}\right.$ in ash) for Illinois bituminous produced no adverse effects on fouling and slagging and demonstrated that mill capacity was more than adequate if the air to the mill was increased. Testing a crusher-dryer ahead of the pulverizer substantially increased mill capacity and reduced power requirements. 


\section{DRAFT}

\section{ISSUE: COAL ORGANIC MINERAL ANALYSIS \\ EERC Expertise (0-5): 5 \\ Research Priority (0-5): 2}

\section{Summary}

Determination of organically bound coal inorganic content using chemical fraction methods is a mature analysis procedure. It is of particular importance with subbituminous and lignite coals which contain substantial amounts of $\mathrm{Ca}$ and $\mathrm{Na}$ attached to coal carboxylic acid groups. Some questions remain with the technique, including the effect of $\mathrm{pH}$ change during extractions, methods to account for extractable $\mathrm{Si}$, and the significance of possible ammonium acetate extractable $\mathrm{Fe}$ and $\mathrm{Al}$ in tropical coals.

\section{Research Questions}

- The amount and effect of soluble Si species on the chemical fraction normalization

- The effect of $\mathrm{pH}$ changes during extractions on the chemical fractionation results

- The role of water and ammonium acetate soluble Al and Fe species in soils and coals mined in a tropical setting.

\section{Applicable EERC Research \\ Project Sodium}

The project final report contains a description of the chemical fractionation procedure along with the mineral species expected to be removed at each step. The CHF procedure has been modified to include an initial water extraction to remove water-soluble minerals prior to extraction with ammonium acetate.

\section{Combustion Inorganic Transformations}

The chemical fractionation technique was further refined and developed in this project and with the combination of computer controlled scanning electron microscopy (CCSEM) mass balances of total coal inorganic constituents were performed. Over ten different U.S. coals were part of this inorganic characterization.

\section{Advanced Combustion Engineering Research Center - Brigham Young University and University of Utah \\ Chemical fraction and coal mineral inorganic mass balances were performed and the information and data was used in devising predictive ash transformation models as supplemental algorithms for the Advanced Combustion Engineering Research Center (ACERC) computational fluid dynamics codes termed PCGC-2 and PCGC-3.}

\section{Validation of Fireside Performance Indices - Fouling Assessment of Coal and Soil-Waste Blends}

Three samples of soil-waste (soil contaminated with organics) were examined by CHF analysis as part of a program to determine the slagging and fouling impacts of cofiring the soil-waste with coal in a cyclone-fired utility boiler. It was noted that the bulk chemistry calculated from CCSEM data differed significantly from the XRFA bulk chemistry of two of the soils. The CHF analysis of these soils gave very high levels of aluminum and iron extraction by ammonium acetate. The soils appear to be laterites, with high concentrations 


\section{DRAFT}

of iron and aluminum hydroxides present. Although not stated, similar behavior may appear in coals mined in tropical locations.

\section{Key Literature}

Benson, S.A.; Fegley, M.M.; Hurley, J.P.; Jones, M.L.; Kalmanovitch, D.P.; Miller, B.G.; Miller, S.F.; Steadman, E.N.; Schobert, H.H.; Weber, B.J.; Weinmann, J.R.; Zobeck, B.J. "Project Sodium: A Detailed Evaluation of Sodium Effects in Low-Rank Coal Combustion Systems," final technical report; EERC publication, July 1988.

Benson, S.A.; Hurley, J.P.; Jones, M.L.; Kalmanovitch, D.P.; Ness, S.R.; Nowok, J.; Puffe, W.; Ramanathan, M.; Steadman, E.N.; Toman, D.L.; Zygarlicke, C.J. "Project Sodium: Follow-On Work to the Original Evaluation of Sodium Effects in Low-Rank Coal Combustion Systems," final technical report and executive summary; EERC publication, Jan. 1992.

Zygarlicke, C.J.; Katrinak, K.A. "Combustion Inorganic Transformations," final technical progress report for the period April 1, 1986 - Dec. 31, 1992, for U.S. DOE DE-FC2186MC10637; EERC publication, 1992.

Zygarlicke, C.J.; Jones, M.L.; Steadman, E.N.; Benson, S.A. "Characterization of Mineral Matter in ACERC Coals," report for Brigham Young University and the University of Utah Advanced Combustion Engineering Research Center; EERC publication, 1990; 32 p.

Miller, R.N.; Given, P.H. "Variations in Organic Constituents of Some Low-Rank Coals," in Ash Deposits and Corrosion Due to Impurities in Combustion Gases; Bryers, R.W., Ed.; Engineering Foundation: 1977; pp 39-50.

Twenty to thirty elements were determined in four drill cores. The elements $\mathrm{Ca}, \mathrm{Na}, \mathrm{K}, \mathrm{Sr}$, $\mathrm{Mg}, \mathrm{Mn}$ are present in ion-exchangeable form bound to carboxylic acid groups in the coal. $\mathrm{Al}, \mathrm{Ti}, \mathrm{Be}, \mathrm{V}$ are present as chelated organometallic complexes. The paper contains a description of the $\mathrm{CHF}$ procedures and mineral associations.

Benson, S.A.; Holm, P.A. "Comparison of Inorganic Constituents in Three Low-Rank Coals," Indust. Eng. Chem. Prod. Res. Develop. 1985, 24, 184-189.

The association of fourteen elements (Al, Ba, Ca, Cr, Cu, Fe, K, Mg, Mn, Na, Ni, Si, Sr, and Ti) in a North Dakota lignite, a Texas lignite and a Montana subbituminous coal were examined by chemical fractionation. Ion-exchangeable elements associated with carboxylic acid groups and extracted by $1 \mathrm{M}$ ammonium acetate were $\mathrm{Ba}, \mathrm{Ca}, \mathrm{Mg}, \mathrm{Mn}, \mathrm{Na}$, and $\mathrm{Sr}$. $\mathrm{Al}$, $\mathrm{Ba}, \mathrm{Cr}, \mathrm{Cu}, \mathrm{Fe}, \mathrm{Ni}, \mathrm{Sr}$, and $\mathrm{Ti}$ were extracted by $1 \mathrm{M} \mathrm{HCl}$ and are present either as coordination complexes or as acid-decomposable minerals. Remaining inorganics are present as quartz, clays, and sulfides. The three coals show significant differences in the amounts and mode of occurrence of the elements present.

Karner, F.R.; Zygarlicke, C.J.; Brekke, D.W.; Steadman, E.N.; Benson, S.A. "New Analysis Techniques Help Control Boiler Fouling," Power Eng. 1994, 98, 35-38.

A good applied approach to using chemical fractionation data, CCSEM mineralogy, and scanning electron microscopy analysis on coal boiler ash fouling deposits is demonstrated in this paper. The mechanics of how organically bound inorganics interact with aluminosilicate 


\section{DRAFT}

clays to form tenacious fouling deposits in the convective pass region of a boiler are described.

Benson, S.A.; Jones, M.L.; Harb, J.N. “Ash Formation and Deposition,” in Fundamentals of Coal Combustion for Clean and Efficient Use; Smoot, L.D., Ed., Elsevier: New York; pp 299-374.

A fairly good book article is put forward here which summarizes the development and application of chemical fractionation and CCSEM techniques for determining inorganic quantities in several different types and ranks of coal. The CCSEM technique is described as a research tool for characterization of coal and ash byproducts and as an important technique for providing sound modeling input data.

Hurley, J.P.; Schobert, H.H. “Ash Formation During Pulverized Subbituminous Coal Combustion: 1. Characterization of Coals and Inorganic Transformations During Early Stages of Burnout," Energy Fuels 1992, 6, 45-58.

Hurley, J.P.; Schobert, H.H. "Ash Formation During Pulverized Subbituminous Coal Combustion: 2. Inorganic Transformations During Middle and Late Stages of Burnout," Energy Fuels 1993, 7, 542-553.

Katrinak, K.A.; Hurley, J.P. "Origins of Fine Particles in a Power Plant Plume as Determined Using Individual Particle Analysis," In Proceedings of the 51st Annual Meeting of the Microscopy Society of America; Bailey, G.W.; Rieder, C.L., Eds.; San Francisco Press: 1993.

Hurley, J.P. “Sodium in Low-Rank Coal,” J. Coal Qual. 1986, Oct., 146-149.

Hurley, J.P.; Steadman, E.N.; Kleesattel, D.R. "Distribution of Inorganics," final report for the period ending March 31, 1986, for DOE/FE/60181-2094; EERC publication, June 1986; 56 p.

Falcone, S.K.; Hurley, J.P.; Schobert, H.H. "The Effects of the Ion-Exchangeable Cations on Coal Ash Mineralogy,” AIChE Div. Fuel Petrochem. Prepr. 1985.

Lignite samples having high and low sodium content were ion exchanged and ashed at $150^{\circ}, 750^{\circ}$, and $1000^{\circ} \mathrm{C}$. Ashes produced were analyzed by XRD to determine crystalline phases. The mineral phases identified for $150^{\circ}$ ash were quartz, pyrite, and kaolinite; at $750^{\circ} \mathrm{C}$, anhydrite, hematite, magnetite, nosean, and melilite; additional phases at $1000^{\circ} \mathrm{C}$, hauyne and pyroxene. Significant differences in melilite formation were noted for highsodium coal before and after ion exchange.

Higgins, R.S.; Kiss, L.T.; Allardice, D.J.; George, A.M.; King, T.N.W. Properties of Brown Coals from the Latrobe Valley - Basis for the Evaluation of Quality; Report No. SC/80/17, State Electricity Commission of Victoria, Australia, Aug. 1980, 120 p.

Physical and chemical properties of Latrobe Valley brown coals are evaluated. Physical properties include maceral structure, moisture forms, density, surface area, porosity, hardness, and color. Moisture, heating value, volatile matter, and $\mathrm{H} / \mathrm{C}$ ratio are related to lithotype; $\mathrm{S}$ and $\mathrm{N}$ are not. Carboxyl oxygen content of about $2.5 \mathrm{meq} / \mathrm{g}$ is $10 \%$ to $50 \%$ combined with ions of $\mathrm{Na}, \mathrm{Mg}, \mathrm{Ca}, \mathrm{Fe}$, and $\mathrm{Al}$. Small amounts of mineral content are 


\section{DRAFT}

primarily clay and pyrite. Ash content averages $1.8 \%$ on a dry basis. Derived ash fouling indices are presented.

Paulson, L.E.; Fowkes, W.W. Changes in Ash Composition of North Dakota Lignite Treated by Ion Exchange; U.S. Bureau of Mines RI 7176, 1968, 18 p.

Lignite was washed with various ionic solutions to investigate the alteration of the inorganic component by ion exchange. A major portion of the inorganic material in the lignite was shown to be combined in an ion exchangeable form with the organic component. Ions of higher valance substituted preferentially at equal concentrations. Coal particle size was a critical factor in determining the rate of exchange.

Zygarlicke, C.J.; McCollor, D.P. "Fouling Assessment of Coal and Soil-Waste Blends Phase I," final report to Duke Power; Sept. 1995. 


\section{DRAFT}

\section{ISSUE: CCSEM DETERMINATION OF COAL MINERAL CONTENT EERC Expertise (0-5): 5 \\ Research Priority (0-5): 3}

\section{Summary}

The CCSEM technique has provided a significant advancement in the understanding of ash transformation processes in coal combustion systems. Early work by Huggins et al. (1980) has been refined and applied by others, including the EERC, to provide a necessary technique for acquiring detailed analysis coal minerals for model predictions. Some refinement is still needed, particularly in standardization of procedures and improvement in agreement between laboratories. CCSEM provides size and inference of mineral species from point elemental analyses for mineral particles routinely between 1-100 $\mu \mathrm{m}$. A special fine-particle technique has been developed for analysis in the $0.1-1 \mu \mathrm{m}$ size range.

\section{Research Questions}

- Development of standardized CCSEM calibration procedures

\section{Applicable EERC Research}

\section{Combustion Inorganic Transformations}

The development and improvement of the CCSEM technique to quantify coal minerals is reviewed. Improvements included standards, three magnification protocol, image analysis to determine mineral grain juxtaposition, and ZAF correction. A small particle analysis method was also developed to quantify particles as small as $0.1 \mu \mathrm{m}$.

\section{Key Literature}

Benson, S.A.; Fegley, M.M.; Hurley, J.P.; Jones, M.L.; Kalmanovitch, D.P.; Miller, B.G.; Miller, S.J.; Steadman, E.N.; Schobert, H.H.; Weber, B.J.; Weinmann, J.R.; Zobeck, B.J. "Project Sodium: A Detailed Evaluation of Sodium Effects in Low-Rank Coal Combustion Systems," final technical report; EERC publication, July 1988.

Benson, S.A.; Hurley, J.P.; Jones, M.L.; Kalmanovitch, D.P.; Ness, S.R.; Nowok, J.; Puffe, W.; Ramanathan, M.; Steadman, E.N.; Toman, D.L.; Zygarlicke, C.J. "Project Sodium: Follow-On Work to the Original Evaluation of Sodium Effects in Low-Rank Coal Combustion Systems," final technical report and executive summary; EERC publication, Jan. 1992.

Zygarlicke, C.J.; Katrinak, K.A. “Combustion Inorganic Transformations,” final technical progress report for the period April 1, 1986 - Dec. 31, 1992, for U.S. DOE DE-FC2186MC10637; EERC publication, 1992.

Zygarlicke, C.J.; Jones, M.L.; Steadman, E.N.; Benson, S.A. "Characterization of Mineral Matter in ACERC Coals," report to Brigham Young University and the University of Utah Advanced Combustion Engineering Research Center; EERC publication, 1990; 32 p.

Galbreath, K. et al. "Collaborative Study of Quantitative Coal Mineral Analysis Using ComputerControlled Scanning Electron Microscopy,” Fuel 1997, 75 4, 424-430. 


\section{DRAFT}

Six laboratories participated in a comparative study of CCSEM analysis of coal minerals. Five analyses were performed by most laboratories on Pittsburgh No. 8, Illinois No. 6, and Prince bituminous coals. Repeatability relative standard deviation was $<20 \%$ for calcite, pyrite, kaolinite, and quartz. Reproducibility of kaolinite was the poorest, and that of pyrite was the best. Although pyrite determination was the most precise, mineral calculations indicate that the results are overbalanced. A standardized calibration procedure is needed to improve agreement between laboratories.

Kong, L.; Zygarlicke, C.J.; Benson, S.A. "Computer-Controlled Analyses of Minerals in Coal," in Proceedings of the Thirteenth Annual International Pittsburgh Coal Conference: Coal-Energy and the Environment; Chiang, S.H., Ed.; Vol. 1, pp 228-233.

The paper describes the precision and accuracy of CCSEM results as studied by two different laboratories. Quartz, kaolinite, are some of the coal minerals that were compared for size and quantity between the two laboratories, for two different coals. It was concluded that CCSEM methods for quantifying coal minerals have improved greatly since the inception of the method and are an excellent tool for providing input into predictive coal and ash evaluation models.

Katrinak, K.A.; Zygarlicke, C.J. "Size-Related Variations in Coal Fly Ash Composition as Determined Using Automated Scanning Electron Microscopy," Fuel Process. Technol. 1995, 44, 71-79.

The CCSEM capabilities for examining fly ash particles that are below 1 micron in average diameter are described in this paper. Normal coal and fly ash analysis of mineral and ash particles using CCSEM is limited to about 1 micron of greater due to beam spot sizes and obtaining accurate chemical information. A new techinque minimizes the SEM beam spot size while optimizing chemical information gained by adjusting SEM acceleration voltage and beam current. Results include calibration of the technique on known compounds. The technique has far reaching applications with the increased interest in reducing levels of fine particulate in the less than 2.5 micron range from the earths atmosphere.

Huggins, F.E.; Kosmack, D.A.; Huffman, G.P.; Lee, R.J. "Coal Mineralogies by SEM Automatic Image Analysis,” Scan. Elect. Microsc. 1980, 1, 531-540.

Procedures for using SEM automatic image analysis to obtain quantitative mineral descriptions are delineated. Experimental tests indicate that the precision and accuracy are comparable to other methods, but that pyrite is overestimated. The technique is more sensitive to minor components than other methods and also provides mineral particle size information. Results are summarized describing the effects of coal washing and the reconstruction of paleoenvironments for coal quality determination.

Jones, M.L.; Kalmanovitch, D.P.; Steadman, E.N.; Zygarlicke, C.J.; Benson, S.A. "Application of SEM Techniques to the Characterization of Coal and Coal Ash Products," in Advances in Coal Spectroscopy; Meuzelaar, H., Ed.; Plenum: New York, 1989.

The book article is a good synopsis of a the variety of CCSEM, point count, and SEM morphological analyses that were used for understanding the mechanisms of ash and deposit formation during coal combustion. Several ACERC program coals were part of the study 


\section{DRAFT}

and much of the data was used for developing predictive fouling and slagging models in conjunction with the ACERC PCGC codes.

Zygarlicke, C.J.; Steadman, E.N. "Advanced SEM Techniques to Characterize Coal Minerals,"

Scan. Microsc. 1990, 4 (3), 579-590.

The paper describes some of the earlier work performed at the EERC using SEM methods for coal mineral analysis. Much effort is put forth describing the technical aspects of CCSEM and the methods for pigeonholing minerals chemically using the energy dispersive spectral data.

Skorupska, N.M.; Carpenter, A.M. "Computer-Controlled Scanning Electron Microscopy of Minerals in Coal," IEA Coal Research Perspectives, Dec. 1993; IEAPER/07.

The paper is a summary report of CCSEM technique at the time, covering methods, reproducibility, and the analysis results and their significance in predicting coal ash deposition behavior.

Benson, S.A.; Jones, M.L.; Harb, J.N. “Ash Formation and Deposition,” in Fundamentals of Coal Combustion; Smoot, L.D., Ed.; Elsevier: New York, 1993; pp 299-373.

This book article summarizes the development and application of chemical fractionation and CCSEM techniques for determining inorganic quantities in several different types and ranks of coal. The CCSEM technique is described as a research tool for characterization of coal and ash byproducts and as an important technique for providing sound modeling input data.

Hurley, J.P.; Schobert, H.H. "Ash Formation During Pulverized Subbituminous Coal Combustion: 1. Characterization of Coals and Inorganic Transformations During Early Stages of Burnout," Energy Fuels 1992, 6, 45-58.

Hurley, J.P.; Schobert, H.H. "Ash Formation During Pulverized Subbituminous Coal Combustion: 2. Inorganic Transformations During Middle and Late Stages of Burnout," Energy Fuels 1993, 7, 542-553.

Nsakala, N.Y.; Patel, R.L.; Raymond, D.R.; Hargrove, M.J.; Hurley, J.P.; Benson, S.A. "Effects of Coal Natures and Cleaning Processes on the Physicochemical and Reactivity Characteristics of Beneficiated Coal-Based Products," Presented at the 16th International Conference on Coal and Slurry Technologies, Clearwater, FL, April 22-25, 1991.

Hurley, J.P.; Zygarlicke, C.J.; Chow, O.K.; Hargrove, M.J. "Physical and Chemical Changes in Fly Ash and Deposits Caused by Coal Beneficiation," in Inorganic Transformations and Ash Deposition During Combustion; Benson, S.A., Ed.; American Society of Mechanical Engineers: New York, 1992; pp 345-366.

Katrinak, K.A.; Brekke, D.W.; Hurley, J.P. "Freeze-Dried Dispersions for Automated Scanning Electron Microscope Analysis of Individual Submicron Airborne Particulates," in Proceedings of the 50th Annual Meeting of the Electron Spectroscopy Society of America; Bailey, G.W.;

Bentley, J.; Small, J.A., Eds.; San Francisco Press: 1992. 


\section{DRAFT}

O'Keefe, C.A.; Strobel, T.M.; Hurley, J.P. "Development of Advanced Scanning Electron Microscopy Techniques for Characterization of Submicron Ash," Presented at the Control of particulate Processes IV, Alberta, Canada, May 14-19, 1995.

Hurley, J.P.; Benson, S.A. “Ash Deposition at Low Temperatures in Boilers Burning HighCalcium Coals: 1. Problem Definition,” Energy Fuels 1995, 9, 775-781. 


\title{
DRAFT
}

\author{
ISSUE: HIGH-TEMPERATURE COMBUSTION DEPOSITION $\left(>1050^{\circ} \mathrm{C}\right)$ \\ EERC Expertise (0-5): 5 \\ Research Priority (0-5): 3
}

\section{Summary}

There has been a plethora of research and published results both from the EERC and other research institutions over the last century pertaining to high temperature zone $\left(>1050^{\circ} \mathrm{C}\right)$ silicate and sulfate based ash deposition. Research in the area of slag formation in the radiant portion of a conventional combustion system has probably been more prevalent than for research in fouling deposits that are more associated with the convective heat absorbing sections of a boiler. Lower rank coals and U.S. Powder River Basin (PRB) coals have by far the least amount of published and studied information, however, the last 25 years has seen a great influx of research in ash fouling deposition for western U.S. coals. In general, the mechanisms of ash transformation from coal minerals to fly ash, ash transport to deposition surfaces, ash sticking and surface viscosity development, and deposit strength development have been studied the most intensely for high temperature regimes. Various models or algorithms have been proposed to help predict the behavior of ash from coals, but a reliable all inclusive model has yet to be configured.

\section{Research Questions}

- A major unanswered question is the actual relationship of calculated viscosity and percentage of liquid phase material to ash deposition behavior, particularly in the high-viscosity regime of $10^{7}$ poise where conventional rotating-bob viscosity measurements are not possible.

- A second major unanswered question is the prediction of ash removability by sootblowing from fundamental coal ash chemistry.

\section{Applicable EERC Research \\ U.S. Bureau of Mines and U.S. DOE Grand Forks Energy Technology Center Low-Rank Coal Research}

A great deal of experimental information has been assimilated over the years regarding hightemperature fouling behavior during combustion under programs conducted by the U.S Bureau of Mines and the U.S Department of Energy at the Grand Forks Energy Technology Center, concentrating primarily on low-rank western coals. Data from several hundred pilot-scale combustion tests, along with supporting coal and ash analyses are archived and available for examination. Key contributions include the proposed mechanisms for ash deposition from low-rank coals and the recognition of the role of sodium in the deposition process for high-sodium lignite fuels. The following key literature references include the significant findings of these programs.

\section{Project Sodium}

Project Sodium dealt with deposition issues specifically related to high-sodium lignite coals. Results were obtained from laboratory studies, pilot-scale testing, and limited full-scale testing. In the high-temperature regime, deposit initiation by the classic sodium sulfate inner white layer on the tube surface, followed by transition to a silicate-based deposit was reaffirmed. A key finding was that the chemical association of sodium was crucial to the degree of fouling experienced. Early chemical fractionation experiments indicated that 


\section{DRAFT}

organically-bound sodium contributed to severe deposition, while sodium aluminosilicate clays were relatively benign. In the deposits, sodium was found to be associated with amorphous glass phases, indicative of sodium having formed low-melting eutectics with aluminosilicate ash material.

\section{ACERC Project}

Studies were performed under the project to examine factors that influence initiation of ash deposition. Five coals, including lignite, subbituminous, and bituminous, were combusted and the initial deposits formed along with the bulk fly ash examined using scanning electron microscopy techniques. Initial adhering particles consisted primarily of iron- iron-calciumand iron-silica-aluminum-rich particles. The enriched particles were common to all the initial deposits with abundance determined by concentration in the original coal ash. The great majority of particles clustered in groupings above a certain critical mass and below a critical viscosity regardless of individual compositions. The propensity for initial ash deposition could be related to the fraction of bulk fly ash particles with sufficient kinetic energy to inertially impact the substrate and with sufficiently low viscosity to adhere on impact.

\section{Coal Beneficiation Project}

A U.S. DOE Clean Coal project involving ABB-CE and EERC focused on coal beneficiation using floating methods. EERC performed coal mineral and deposit characterization using CCSEM and other advanced methods of inorganic analysis. Fly ash and deposits were generated from several baseline and beneficiated fuels and the properties of the ash components were correlated to the coal processing. In some instances, coal cleaning reduced the amount of ash but concentrated coal inorganics that were instrumental in causing tenacious fouling deposits.

\section{Development of Fireside Performance Indices Project}

Ash deposition indices (slagging and high-temperature fouling) were formulated from existing bench-, pilot-, and full-scale combustion testing data and knowledge of inorganic transformations, entrained ash formation, and ash deposition. Additional bench-scale testing in drop-tube furnaces (DTFs) was performed on eight Powder River Basin (PRB) subbituminous coals to refine and verify the ash deposition indices and to develop ash removability indices (slag tapping and sootblowing). Slagging and conventional and low$\mathrm{NO}_{\mathrm{x}}$ high-temperature fouling were simulated. Deposit growth rates, sticking coefficients, in situ adhesion strengths, crushing strengths, initial slagging temperatures, porosities, and chemical and phase compositions were determined. In general, the low- $\mathrm{NO}_{\mathrm{x}}$ combustion conditions produce high-temperature fouling deposits that have less adhesion and crushing strengths relative to those produced in conventional combustion conditions.

\section{Development Fouling Algorithms for the Coal Quality Expert}

Dynamic fouling algorithms were developed to predict ash transformations during conventional coal combustion, ash transport to convective pass fouling heat exchange surfaces, rate of fouling deposition, deposit strength development, and deposit shedding or sootblowing effectiveness. The algorithms were developed based in part on ash deposition theory and empirical data and were part of a comprehensive coal quality impact model for conventional boilers called the Coal Quality Expert (CQE). Coal mineral data and boiler 


\section{DRAFT}

design and dynamic operating data were used as inputs. The models were hooked to a boiler engine in the $\mathrm{CQE}$ so that ash deposition occurred in a particular region of the boiler, flue gas temperatures would also increase in that temperature and ash deposit mechanisms could be updated.

\section{Key Literature}

Sondreal, E.A.; Tufte, P.H.; Beckering, W. "Ash Fouling in the Combustion of Low-Rank Western U.S. Coals,” Combust. Sci. Technol. 1977, 16, 95-110.

Honea, F.I. "Studies of Ash-Fouling Potential and Deposit Strength in the GFTEC Pilot Plant Test Furnace," in Fouling and Slagging Resulting from Impurities in Combustion Gases; Bryers, R.W.; Cole, S.S., Eds.; In Proceedings of the Engineering Foundation Conference; Henniker, NH, July 12-17, 1981; pp 117-142.

Honea, F.I. "Survey of Ash-Related Losses at Low-Rank Coal-Fired Utility Boilers," in Fouling and Slagging Resulting from Impurities in Combustion Gases; Bryers, R.W.; Cole, S.S., Eds.; In Proceedings of Engineering Foundation Conference; Henniker, NH, July 12-17, 1981; pp $527-539$.

Rindt, D.K.; Jones, M.L.; Schobert, H.H. "Fouling and Slagging Resulting from Impurities in Combustion Gases," Proceedings of the Engineering Foundation Conference; Bryers, R.W., Ed.; Henniker, NH, July 12-17, 1981; pp 17-35.

Tufte, P.H.; Beckering, W. "A Proposed Mechanism for Ash Fouling Burning Northern Great Plains Lignite," J. Eng. Power 1975, July, 407-412.

Sondreal, E.A.; Kube, W.R.; Elder, J.L "Analyses of the Northern Great Plains Province Lignites and Their Ash: A Study of Variability," Bureau of Mines RI 7158, 1968, 94 p.

Benson, S.A.; Fegley, M.M.; Hurley, J.P.; Jones, M.L.; Kalmanovitch, D.P.; Miller, B.G.; Miller, S.J.; Steadman, E.N.; Schobert, H.H.; Weber, B.J.; Weinmann, J.R.; Zobeck, B.J. "Project Sodium: A Detailed Evaluation of Sodium Effects in Low-Rank Coal Combustion Systems," final technical report; EERC publication, July 1988.

Benson, S.A.; Hurley, J.P.; Jones, M.L.; Kalmanovitch, D.P.; Ness, S.R.; Nowok, J.; Puffe, W.; Ramanathan, M.; Steadman, E.N.; Toman, D.L.; Zygarlicke, C.J. "Project Sodium: Follow-On Work to the Original Evaluation of Sodium Effects in Low-Rank Coal Combustion Systems," final technical report and executive summary; EERC publication, Jan. 1992.

Hurley, J.P.; Zygarlicke, C.J. "Physical and Chemical Changes in Fly Ash and Deposits Caused by Coal Beneficiation," in Inorganic Transformations and Ash Deposition During Combustion; Benson, S.A., Ed.; American Society of Mechanical Engineers: New York, 1992; pp 345-366.

Zygarlicke, C.J.; Katrinak, K.A. "Combustion Inorganic Transformations," final technical progress report for the period April 1, 1986 - Dec. 31, 1992, for U.S. DOE DE-FC2186MC10637; EERC publication, 1992. 


\section{DRAFT}

Benson, S.A.; Jones, M.L.; Harb, J.N. “Ash Formation and Deposition,” in Fundamentals of Coal Combustion; Smoot, L.D., Ed.; Elsevier: New York, 1993; pp 299-373.

An excellent explanation of the physical and chemical transformations of mineral and organically bound inorganics into entrained ash and ash deposits, and the associated mechanisms of formation and deposition are given in this book chapter. Ash formation and deposition results for several different U.S. coals are given based on laboratory and pilot scale combustion testing. This work was primarily based on the DOE CIT and ACERC projects.

Srinivasachar, S.; Helble, J.J.; Boni, A.C. "An Experimental Study of the Inertial Deposition of Ash Under Coal Combustion Conditions," Twenty-Third Symposium (International) on Combustion; The Combustion Institute: 1990; pp 1305-1312.

The study identified particle viscosity as the dominant ash variable in determining inertial deposition of ash. A critical viscosity for adhesion was identified which was dependent on particle kinetic energy. The critical viscosity range was several orders of magnitude higher than currently used to predict slagging propensity in boilers. Deposition experiments were conducted with a San Miguel lignite coal to verify the applicability to coal ash deposition.

McCollor, D.P.; Zygarlicke, C.J.; Allan, S.E.; Benson, S.A. "Ash Deposition Initiation in a Simulated Fouling Regime," Energy Fuels 1993, 7, 761-767.

The paper describes the significant results of work performed under the ACERC project.

Allan, S.E.; Erickson, T.A.; McCollor, D.P. "Modelng of Ash Deposition in the Convective Pass of a Coal-Fired Boiler," in Application of Advanced Technology to Ash-Related Problems in Boilers, Baxter, L.; DeSollar, R., Eds.; Plenum Press: New York, 1996; pp 451-470.

Bryers, R.W. "Fireside Behavior of Mineral Impurities in Fuels from Marchwood 1963 to the Sheraton Palm Coast 1992," in Inorganic Transformations and Ash Deposition During Combustion; Benson, S.A., Ed.; American Society of Mechanical Engineers: New York, 1992; pp $3-70$.

His summary of recent work in understanding he impact of coal impurities on boiler systems revealed that most of the work performed in ash deposition behavior is in response to critical boiler events or catastrophic events and little study is actually performed methodically. Areas identified as needing more attention include coal mineral variability; coal beneficiation, blending, and switching; in situ remedial measures; age hardening of deposits; and loss in thermal effectiveness and thermal properties in general.

Zygarlicke, C.J.; Benson, S.A.; Borio, R.W.; Mehta, A.K. "Examination of Ash Deposition in Full-, Pilot-, and Bench-Scale Testing," Presented at the 3rd International Conference on the Effects of Coal Quality on Power Plants, San Diego, CA, Aug. 25-27, 1992.

Zygarlicke, C.J.; Benson, S.A.; Borio, R.W. "Pilot- and Bench-Scale Combustion Testing of a Wyoming Subbituminous/Oklahoma Bituminous Coal Blend," in Coal-Blending and Switching of Low-Sulfur Western Fuels; Bryers, R.W.; Harding, N.S., Eds.; American Society of Mechanical Engineers: New York, 1994; pp 281-300. 


\section{DRAFT}

McCollor, D.P.; Zygarlicke, C.J.; Benson, S.A. "Mechanisms of Ash Fouling during Low-Rank Coal Combustion," in Applications of Advanced Technology to Ash-Related Problems in Boilers; Baxter, L.; DeSollar, R., Eds.; Plenum Press: New York, 1996; pp 223-235.

Erickson, T.A.; Allan, S.E.; McCollor, D.P.; Hurley, J.P.; Srinivasachar, S.; Kang, S.G.; Baker, J.E.; Morgan, M.E.; Johnson, S.A.; Borio, R. "Modeling of Fouling and Slagging in Coal-Fired Utility Boilers," Fuel Process. Technol. 1995, 44, 155-172.

Nowok, J.W.; Hurley, J.P.; Bieber, J.A. "The Cause of Surface Tension Increase with Temperature in Multicomponent Aluminosilicates Derived from Coal Ash Slags," J. Mat. Sci. 1994, 30, 361-364.

Nowok, J.W.; Hurley, J.P.; Steadman, E.N. "A New Approach to Calculating Coal Ash Viscosity," in The Impact of Ash Deposition on Coal Fired Plants; Williamson, J.; Wigley, F., Eds.; Taylor \& Francis: Bristol, PA, 1994; pp 527-528.

Benson, S.A.; Sondreal, E.A.; Hurley, J.P. "Status of Coal Ash Behavior Research,” in Ash Chemistry in Fossil Fuel Processes, Special Issue of Fuel Process. Technol. 1995, 44 (1-3), $1-12$.

Hurley, J.P.; Watne, T.M.; Nowok, J.W. "The Effects of Atmosphere and Additives on Coal Slag Viscosity," Prepr. Pap.-Am. Chem. Soc., Div. Fuel Chem. 1996, 41 (2), 691-694.

Nowok, J.W.; Hurley, J.P.; Benson, S.A. "The Role of Physical Factors on Mass Transport and Phase Transformation in Melts During Slag Flow and Sintering of Coal Ashes," Prepr. Pap.-Am. Chem. Soc., Div. Fuel Chem. 1996, 41 (2), 676-680.

Strobel, T.M.; Hurley, J.P.; Breder, K.; Holowczak, J.E. "Coal Slag Corrosion and Strength Degradation of Silicon Carbide/Alumina Composites," in Ceramic Engineering \& Science Proceedings; American Ceramic Society: 1994; Vol. 15, No. 4.

Strobel, T.M.; Hurley, J.P.; Senior, C.L.; Holowczak, J.E. "Coal Slag Corrosion of Silicon Carbide-Based Ceramics in a Combustion Environment," in Silicon-Based Structural Ceramics; Sheldon, B.W.; Danforth, S.C., Eds.; The American Ceramic Society: Westerville, OH, 1994; Vol. 42, pp 327-334.

Gronhovd, G.H. "Progress and Problems in Combustion of Lignite from the Northern Great Plains Area," SME/AIME Meeting, Minneapolis, MN, Sept. 1968; No. 68-F-351, 15 p.

Fouling rates determined in the GFERL test furnace were increased by a factor of three as sodium oxide in ash increased from about $1 \%$ to $6 \%$. Fouling rates were comparable at similar levels of sodium, whether the sodium content was the amount naturally occurring in the coal or the sodium had been adjusted by ion exchange or addition of sodium carbonate. Design specifications are given for three new 200-MW class boilers. 


\section{DRAFT}

Gronhovd, G.H.; Wagner, R.J.; Wittmaier, A.J. "A Study of the Ash Fouling Tendencies of a North Dakota Lignite as Related to Its Sodium Content," Society of Mining Engineers Transactions; Sept. 1967, pp 313-322.

Ash deposition was measured on a 54-MW pc-fired boiler burning four lots of North Dakota lignite having sodium contents between $2 \%$ and $9 \%$ ash. The $800^{\circ}$ and $1000^{\circ} \mathrm{F}$ probes were positioned in three locations in the convection section, covering gas temperatures from $1600^{\circ}$ to $2350^{\circ} \mathrm{F}$. Fouling increased linearly with sodium up to $6 \%$ before leveling off; it approximately doubled between $75 \%$ and $90 \%$ of rated load. Only $17 \%$ to $44 \%$ of input ash reached the air heater during nonsootblowing periods.

Schobert, H.H. "Ash and Slag Characterization for Low-Rank Coals," UND Energy Research Center DOE/FE/60181-9; June 1983, 12 p.

Viscosities of 17 lignite and subbituminous coal ash slags were measured between $2100^{\circ}$ and $2700^{\circ} \mathrm{F}$. Correlations based on the $\mathrm{SiO}_{2}-\mathrm{CaO}-\mathrm{Al}_{2} \mathrm{O}_{3}$ phase system, using a modified Watt-Fereday equation, were obtained for three subsets of data categorized by silica content.

Schobert, H.H.; Streeter, R.C.; Diehl, E.K. "Flow Properties of Low-Rank Coal Ash Slags, Implications for Slagging Gasification," Fuel 1985, 64, 1611-1617.

Viscosities of lignitic slags are correlated using a modified Watt-Fereday equation based on the $\mathrm{SiO}_{2}-\mathrm{Al}_{2} \mathrm{O}_{3}-\mathrm{CaO}$ phase system. Effects of heating/cooling hysteresis, oxidizing versus reducing atmospheres, phase separation, and formation of metallic iron are discussed.

Hein, K. "Methods of Prediction of Mineral Matter Behaviour in the Furnace," Pulverized Coal Firing Mineral Matter and Its Effects; University of Newcastle, NSW, Australia: 1979; pp L11.1-6.

This paper reviews the theoretical, analytical, and pilot-scale combustion methods used to evaluate the behavior of coal ash in boilers. Laboratory methods include procedures for ashing, mineral transformation, fusion, sintering, viscosity, emittance, and conductance. The review of theoretical analysis includes thermodynamic calculations and multicomponent phase diagrams. Thus far, practical evaluation relies heavily on pilot-scale combustion tests.

Higgins, R.S.; Johnson, T.R.; Morley, W.J. "Relating Experimental Furnace Results to Full-Scale Boiler Performance," Fouling and Slagging Resulting from Impurities in Combustion Gases; Bryers, R.W., Ed.; Engineering Foundation: New York, 1983; pp 515-525.

Boiler availability, measured as length of time between off-line cleaning, correlated with the SECV fouling index for the range of Latrobe Valley brown coals for which the index was developed. However, availability was not satisfactorily predicted for other coals of more widely varying ash content. It is believed that a measurement of deposit hardness is needed, along with the index of deposit weight, to predict performance for the wider range of ash content.

Rindt, D.K.; Jones, M.L.; Schobert, H.H. "Investigations of the Mechanism of Ash Fouling in Low-Rank Coal Combustion," Fouling and Slagging Resulting from Impurities in Combustion Gases; Bryers, R.W., Ed.; Engineering Foundation: New York, 1983; pp 17-35. 


\section{DRAFT}

A summary of SEM, XRD, and heated stage microscope (HSM) studies on ash deposits. Physical, chemical, and mineralogical characteristics of bonding materials are presented. Interparticle bonding by surface tension due to low melting $\mathrm{Na}_{2} \mathrm{SO}_{4}$ or $\mathrm{Na}-\mathrm{Ca}-\mathrm{SO}_{4}$ eutectic may occur near the tube, and due to sodium melilite in the outer deposit. Crystallization of $\mathrm{CaSO}_{4}$ and calcium melilites from melts may also strengthen deposits. Sodium was vaporized by heating to $950^{\circ} \mathrm{C}$ on the HSM. 


\section{DRAFT}

ISSUE: LOW-TEMPERATURE COMBUSTION DEPOSITION $\left(<1050^{\circ} \mathrm{C}\right)$

EERC Expertise (0-5): 5

Research Priority (0-5): 3

\section{Summary}

Low-temperature deposition in combustion systems is primarily the result of calcium deposition by thermophoresis and impaction followed by subsequent sulfonation, although other alkali and alkaline earth elements may also contribute. Measurements have been made which allow estimates of deposition rate and sulfate strength development.

\section{Research Questions}

- Definition of the temperature range most favorable for sulfonation and sulfate strength development producing the most problematic deposits.

- Calcium in silicate structures and impact on sulfation.

- Methods for mitigation of sulfation and bridging in hot gas filters.

\section{Applicable EERC Research Project Calcium}

The project involved field tests at five full-scale utility boilers, combined with coal and deposit analysis, and bench-scale studies of calcium sulfate-based low-temperature deposition. Four types of low-temperature deposits were identified: upstream massive, upstream enamel, upstream double-crested, and downstream powder deposits. All contain large amounts of sulfur fixed from the gas stream by alkali and alkaline earth elements, particularly calcium. The massive deposits form as fins to windward of the lead tubes of the reheat steam banks, sulfonate and become hard rapidly, and are difficult to remove by sootblowing. Upstream enamel deposits are comprised of particles $<3 \mu \mathrm{m}$ diameter and are highly enriched in calcium. The deposits remain relatively thin, but are very difficult to remove either by sootblowing or offline cleaning. The double-crested deposits are similar to the enamel deposits. The downstream powder deposits form due to gas eddies downstream of the tubes. The deposits are powdery and quite easy to remove, as well as shedding due to their own weight at a thickness of approximately $1 \mathrm{~cm}$. However, these deposits cause the greatest reduction in heat transfer of the low-temperature types, and the location in the economizer often does not permit effective sootblower coverage. Estimations of deposit growth rates at full-scale utility boilers and lab-scale sintering strength development were developed for use in the LEADER program.

\section{Development of Fireside Performance Indices Project}

In the course of the project, low-temperature fouling deposits were produced from three subbituminous coals under conditions simulating conventional and low- $\mathrm{NO}_{\mathrm{x}}$ combustion conditions. The low-temperature fouling deposits generally did not show a significant difference between the conventional and the low- $\mathrm{NO}_{\mathrm{x}}$ condition. This was ascribed to sulfonation of the calcium-rich deposits which is in contrast to the melting and sintering mechanism of deposit strength development that dominates in the high-temperature fouling deposits. The low-temperature fouling deposits were generally depleted in $\mathrm{SiO}_{2}$ and $\mathrm{Na}_{2} \mathrm{O}$ 


\section{DRAFT}

but enriched in $\mathrm{CaO}$ and $\mathrm{MgO}$. Apparently, the amount of organically bound $\mathrm{Ca}$ and $\mathrm{Mg}$ in a coal is an important variable to consider in predicting low-temperature fouling propensity. The low-temperature fouling deposits are also enriched in $\mathrm{SO}_{3}$, as evidenced by the relatively high concentrations of anhydrite. It appeared that deposit porosity was unrelated to deposit crushing or adhesion strength.

\section{Hot-Gas Filter Project}

The EERC performed chemical and physical analyses of ash bridges formed between candle filters in advanced particulate filters. The purpose of the analyses was to quantify the changes in the ash that led to the reduction in bridging. Analyses included advanced SEM techniques to determine the size and composition of ash particles down to 0.1 microns in diameter and high-temperature tensile strength testing. Ash bridges between filters showed greater age and quantities of sulfur and sulfation is one proposed mechanism by which hard bridging deposits form and force apart filter structures causing failure.

\section{Key Literature}

Hurley, J.P.; Benson, S.A.; Erickson, T.A.; Allan, S.E.; Bieber, J. "Project Calcium,” final report, 1992.

Project Calcium involved field tests at five full-scale utility boilers, combined with coal and deposit analysis, and bench-scale studies of calcium sulfate-based low-temperature deposition. Four types of low-temperature deposits were identified: upstream massive, upstream enamel, upstream double-crested, and downstream powder deposits. All contain large amounts of sulfur fixed from the gas stream by alkali and alkaline earth elements, particularly calcium. The deposits tend to be very difficult to remove either by sootblowing or offline cleaning. Estimations of deposit growth rates at full-scale utility boilers and labscale sintering strength development were developed for use in the EERC LEADER program.

Zygarlicke, C.J.; Galbreath, K.C.; McCollor, D.P.; Toman, D.L. "Development of Fireside Performance Indices," final topical report for U.S. DOE DE-FC21-93MC30098; Nov. 1995. In the course of the project, low-temperature fouling deposits were produced from three subbituminous coals under conditions simulating conventional and low- $\mathrm{NO}_{\mathrm{x}}$ combustion conditions. The low-temperature fouling deposits generally did not show a significant difference between the conventional and the low- $\mathrm{NO}_{\mathrm{x}}$ condition. This was ascribed to sulfonation of the calcium-rich deposits which is in contrast to the melting and sintering mechanism of deposit strength development that dominates in the high-temperature fouling deposits. The low-temperature fouling deposits were generally depleted in $\mathrm{SiO}_{2}$ and $\mathrm{Na}_{2} \mathrm{O}$ but enriched in $\mathrm{CaO}$ and $\mathrm{MgO}$. Apparently, the amount of organically bound $\mathrm{Ca}$ and $\mathrm{Mg}$ in a coal is an important variable to consider in predicting low-temperature fouling propensity. The low-temperature fouling deposits are also enriched in $\mathrm{SO}_{3}$, as evidenced by the relatively high concentrations of anhydrite. It appeared that deposit porosity was unrelated to deposit crushing or adhesion strength.

Hurley, J.P.; Erickson, T.A.; Benson, S.A.; Brobjorg, J.N. “Ash Deposition at Low Temperatures in Boilers Firing Western U.S. Coals," Presented at the International Joint Power Generation Conference, San Diego, CA, 1991, 8 p. 


\section{DRAFT}

Benson, S.A.; Hurley, J.P.; Zygarlicke, C.J. "Studies on Calcium-Based Deposition in Utility Boilers," In Proceedings of the Conference on Effects of Coal Quality on Power Plants; St. Louis, MO, Sept. 1990.

Benson, S.A.; Hurley, J.P.; Zygarlicke, C.J.; Steadman, E.N.; Erickson, T.A. "Predicting Ash Behavior in Utility Boilers: Assessment of Current Status," Presented at the Conference on Effects of Coal Quality on Power Plants, Electric Power Research Institute, San Diego, CA, Aug. 1992.

Hurley, J.P.; Watne, T.M.; O’Keefe, C.A.; Katrinak, K.A.; Nowok, J.W.; Roling, T.A.; Dockter, B.A. "Chemical and Physical Analyses of Tidd Hot Gas Filter Ash," In Proceedings of the 13th Annual Pittsburgh Coal Conference; Pittsburgh, PA, Sept. 3-7, 1996; Vol. 1, pp 241-246.

Dockter, B.A.; Hurley, J.P. “Tensile Strength of Ash Cake Beds at High-Temperature Conditions," in High Temperature Gas Cleaning; Schmidt, E.; Gäng, P.; Pilz, T.; Dittler, A., Eds.; Institut für Mechanische Verfahrenstechnik UND Mechanik, Universität Karlsruhe: Karlsruhe, Germany, 1996; pp 157-168.

Hurley, J.P.; Nowok, J.W.; Strobel, T.M.; O'Keefe, C.A.; Bieber, J.A.; Dockter, B.A. "Rates and Mechanisms of Strength Development in Low-Temperature Ash Deposits," in Application of Advanced Technology to Ash-Related Problems in Boilers; Baxter, L; DeSollar, R., Ed.; Plenum Press: New York, 1996; pp 83-96.

Nowok, J.W.; Hurley, J.P.; Benson, S.A. "The Role of Sulphate-Silicate Phase Separation in Sintering Propensities of Coal Fly Ash at 800E-1000EC," J. Inst. Energy 1996, 69, 12-14.

Benson, S.A.; Sondreal, E.A.; Hurley, J.P. "Status of Coal Ash Behavior Research,” in Ash Chemistry in Fossil Fuel Processes, Special Issue of Fuel Process. Technol. 1995, 44 (1-3), $1-12$.

Bieber, J.A.; Hurley, J.P. "Characterization of Ash Deposits in Particulate Filter Systems by Electron Spectroscopy," In Proceedings of the 12th Annual International Pittsburgh Coal Conference; Pittsburgh, PA, Sept. 12-15, 1995; pp 819-824.

Hurley, J.P.; Benson, S.A. “Ash Deposition at Low Temperatures in Boilers Burning HighCalcium Coals: 1. Problem Definition,” Energy Fuels 1995, 9, 775-781.

Hurley, J.P.; Benson, S.A. "Ash Deposition at Low Temperatures in Boilers Burning HighCalcium Coals," in The Impact of Ash Deposition on Coal Fired Plants; Williamson, J.; Wigley, F., Eds.; Taylor \& Francis: Bristol, PA, 1994; pp 19-30.

Senior, C.L.; Boni, A.A.; Helble, J.J.; Srinivasachar, S.; Johnson, S.A.; Hurley, J.P.; Strobel, T.M. "Ash Corrosion Studies of Ceramic Materials for Advanced Coal-Fired Power Generation Cycles," in The Impact of Ash Deposition on Coal Fired Plants; Williamson, J.; Wigley, F., Eds.; Taylor \& Francis: Bristol, PA, 1994; pp 767-778. 


\title{
DRAFT
}

\author{
ISSUE: HIGH-TEMPERATURE GASIFICATION DEPOSITION $\left(>900^{\circ} \mathrm{C}\right)$ \\ EERC Expertise (0-5): 3 \\ Research Priority (0-5): 5
}

\section{Summary}

The current state of knowledge of ash-related issues in gasification systems significantly lags that for conventional combustion. The projected increasing use of gasification in advanced power systems places a high priority on increasing this understanding. High-temperature gasification deposits can result from deposition of lower viscosity iron sulfides, iron aluminosilicates and calcium or calcium-iron aluminosilicate species analogous to high-temperature fouling deposits. The presence of water vapor and a lower ash viscosity relative to combustion system deposits. Much is not yet known regarding ash partitioning, deposition mechanisms, and sintering mechanisms in these systems.

\section{Research Questions}

- The sintering mechanisms for deposit growth and strength development, in particular the role of heterogeneous versus homogeneous condensation.

- Initial ash deposition mechanisms for high-temperature regimes.

- Impacts of various reducing environments on slag or deposit viscosity.

- Key mineral phases affecting deposition in reducing environments.

\section{Applicable EERC Research \\ CABRE I Project}

The CABRE project focused on the development of analytical techniques, production and analysis from bench-scale deposits, measurement of deposit strength, and stability of sulfides under gasification conditions. The formation and strength development of hightemperature deposits appear to result from the low-viscosities of silicate-based phases. Viscosities are generally lower under gasification conditions relative to combustion conditions and the presence of water vapor was shown to further lower the viscosity.

\section{Gasification Ash and Slag Characterization Project}

The project was directed toward the understanding the sintering processes in the temperature range $700^{\circ}-1100^{\circ} \mathrm{C}$. The mass transport in the melt was found to be dependent on both melt composition and local silicate structure, which was highly temperature dependent. A relationship was developed between surface tension/viscosity ratio and base/acid ratio as well as compressive strength development. A method was developed to predict crystalline phases formed at higher temperatures from melts based on minimization of Gibbs free energy. Deposit thermal conductivity was also measured and found to be significantly dependent on chemical and mineralogical composition as well as on deposit porosity. 


\section{DRAFT}

\section{Fuel Utilization Properties}

The project was directed toward mineral and ash transformations under lower oxygen combustion conditions. Several different coals were fired under varying degrees of reducing conditions. With one particular set of Illinois No. 6 fly ash and deposit samples generated in a DTF, reduced iron oxide species were observed using Mössbaur analysis and more iron aluminosilicate versus iron oxide material was generated. Severe gasification reducing conditions, however, were not studied in this project.

\section{Transport Reactor Development Projects}

The Department of Energy has sponsored ongoing research looking at the effectiveness of hot gas filtration systems and fuel processing performance in the Kellog designed Transport Reactor Develop Unit at the EERC. Ash deposits that are typical of full-scale gasification systems have been formed in this unit in various parts of the system. Most of the deposits have been more like agglomerates of silica or dolomite bed material bonded by calcium magnesium aluminosilicate ash from western U.S. PRB subbituminous coal or iron rich oxides or iron rich aluminosilicates with associated alkali from eastern U.S. bituminous coal.

\section{Key Literature}

Koyama, S.; Morimoto, T.; Ueda, A.; Matsuoka, H. "A Microscopic Study of Ash Deposits in a Two-Stage Entrained-Bed Coal Gasifier," Fuel 1996, 75 4, 459-465.

Deposits collected in both high and low-temperature regimes consisted primarily of calcium-aluminosilicate, silica, and carbon. Small amounts of aluminosilicate and calcium silicate were present. Iron was present in all deposits, although no iron sulfide was found. The char carbon acted as a high-melting dispersant, preventing complete sintering and producing weak friable deposits. The effect was marked, increasing the sintering temperature from $780^{\circ} \mathrm{C}$ to $1000^{\circ} \mathrm{C}$.

Mills, K.C.; Rhine, J.H. "The Measurement and Properties of the Physical Properties of Slags Formed During Coal Gasification. 1. Properties Relevant to Fluid Flow," Fuel 1989, 68, 193-200.

The physical properties of the slags studied are highly dependent on the $\mathrm{FeO}-\mathrm{Fe}_{2} \mathrm{O}_{3}-\mathrm{Fe}$ distribution of iron. Models were developed to estimate surface tension and viscosity, but require improvement in predictability.

Nowok, J.W.; Hurley, J.P.; Benson, S.A. "The Role of Physical Factors in Mass Transport During Sintering of Coal Ashes and Deposit Deformation Near the Temperature of Glass

Transformation," American Chemical Society Symposium, New Orleans, LA, March 1996.

The role of melt physical properties such as viscosity, diffusion, and surface and interfacial tension in ash deposits above the glass transformation temperature is discussed. Sintering properties of ash and superplastic like deformations above the glass transformation temperature depends on mass transport phenomena in the intergranular liquid phase.

Zygarlicke, C.J.; McCollor, D.P.; Hurley, J.P.; Swanson, M.L. "Studies in Ash Behavior for Advanced Power Systems," EPRI Gasification Technologies Conference, San Francisco, CA, Oct. 5-8, 1997, 9 p. 


\section{DRAFT}

Research aimed at understanding the mechanisms of ash formation and deposition in coalfired advanced power systems such as integrated gasification combined cycle, entrained flow gasification, and pressurized combustion is crucial for current successful operation and future design of these systems. Work has been done extensively at the Energy \& Environmental Research Center to focus on key governing factors in ash deposit formation in advanced power systems. One key factor in the formation of troublesome deposits is the development of viscous flow properties in partially molten ash. The ability for material to flow and encapsulate or bond ash particles is the most important factor in ash deposit formation in any system. Advanced systems produce ash in highly reducing environments where viscosities are usually driven to lower magnitudes and potential for interaction between mineral components is greater. Current design and operation also tend to produce ash deposits that form as a result of low temperature-high viscosity types of ash sintering that is difficult to predict. Tensile strength of filter blinding deposits increases due to more efficient particle packing of certain particle sizes. Slight sintering was noted in these types of filter blinding deposits at temperatures beginning at $700^{\circ} \mathrm{C}$, with sintering at $750^{\circ} \mathrm{C}$ creating even stronger deposit strengths. Alkali sulfate liquids and the sintering mechanisms associated with low liquid phase viscosities play development play a major role in causing the formation of liquid bridging or neck areas between fly ash particles in a filter blinding deposit, the generation of coatings around particles either being deposited or already deposited, and the encapsulation of fly ash matrix particles by flowing material.

Benson, S.A.; Sondreal, E.A. "Impact of Low-Rank Coal Properties on Advanced Power Systems," Proceedings of Thirteenth Annual International Pittsburgh Coal Conference - Coal, Energy, and the Environment; Chiang, S., Ed.; Vol. 1, pp 484-498.

Deposits formed in the riser and disengager of the TRDU consisted of calcium and magnesium rich coatings on the surface of the aluminosilicate bed material. The bed material appeared to react with the coal ash and sulfided dolomite to form coatings of lowmelting calcium-magnesium aluminosilicates.

Zygarlicke, C.J.; McCollor, D.P.; Folkedahl, B.C.; Swanson, M.L.; Musich, M.A. “Advanced Power Systems: Subtask 3.18 - Ash Behavior in Power Systems," semiannual report for the period June 30 - Dec. 31, 1997, for U.S. DOE DE-FC21-93MC30097; 36 p.

Low temperature deposition in TRDU for Wyodak, SUFCo, and Illinois No. 6 coals was observed with calcium aluminosilicate cementing material and some evidence of iron spinels forming in melt structure.

Hurley, J.P.; Dockter, B.A.; Roling, T.A.; Nowok, J.W.; Swanson, M.L. "Hot Gas Filter Ash Characterization," In Proceedings of Engineering Foundation Conference on Impact of Mineral Impurities in Solid Fuel Combustion, Kona, HI, Nov. 2-7, 1997; Wall, T.F.; Baxter, L.L., Eds. Mechanisms of sticking for fine particles in hot gas filtration devices include electrostatic and van der Waals attractions and mechanical, liquid, and solid bridging. Size and composition of particles, cake porosity, gas composition, and system temperature influence magnitude of filter caking, deposit bridging, and deposit tenacity.

Erickson, T.A.; Brekke, D.W.; Nowok, J.W.; Tibbetts, J.E.; Allan, S.E.; Benson, S.A.; Steadman E.N. "Coal Ash Behavior in Reducing Environments," final report; Jan. 1995. 


\section{DRAFT}

The CABRE project focused on the development of analytical techniques, production and analysis from bench-scale deposits, measurement of deposit strength, and stability of sulfides under gasification conditions. The formation and strength development of hightemperature deposits appear to result from the low-viscosities of silicate-based phases. Viscosities are generally lower under gasification conditions relative to combustion conditions and the presence of water vapor was shown to further lower the viscosity.

Zygarlicke, C.J.; Nowok, J.W.; Kiel, J. "Coal Ash Behavior in Reducing Environments (CABRE) II, Year 1," final report; Dec. 1997, 41 p.

Mechanisms of ash deposit formation, sintering, and liquid phase viscosity-temperature relationships and are being investigated for several coals using mostly laboratory scale experimentation with comparisons to limited field data.

Payonk, R.J.; Stultz, J. “Operating Experience at the Wabash River Coal Gasification Repowering Project," EPRI Gasification Technologies Conference, San Francisco, CA, Oct. 5-8, 1997, p. 12.

The DOE Clean Coal Technology program is in-part funding a repowering project with PSI Energy and Destec. In integrated coal gasification combined cycle power plant, using Destec's coal gasification technology to repower a coal combustion unit at West Terre Haute, Indiana. Syngas containing entrained particulate and sulfur exits the gasifier and ice cooled in a firetube heat recovery boiler system. Raw gas leaving the boiler passes through a barrier filter unit to remove particulate (char) for recycle to the first stage of the gasifier. Problems were experienced in initial gasification runs with ash deposition at the inlet to the firetube boiler (higher temperature deposition) and in the barrier filter system where ceramic candle filters elements failed causing particulate breakthrough.

Steadman, E.N.; Nowok, J.W. "Gasification Ash and Slag Characterization," final technical progress report for the period April 1, 1986 - June 30, 1993, for U.S. DOE DE-FC2186MC10637, July 1993.

The project was directed toward the understanding the sintering processes in the temperature range $700^{\circ}-1100^{\circ} \mathrm{C}$. The mass transport in the melt was found to be dependent on both melt composition and local silicate structure, which was highly temperature dependent. A relationship was developed between surface tension/viscosity ratio and base/acid ratio as well as compressive strength development. A method was developed to predict crystalline phases formed at higher temperatures from melts based on minimization of Gibbs free energy. Deposit thermal conductivity was also measured and found to be significantly dependent on chemical and mineralogical composition as well as on deposit porosity. 


\section{DRAFT}

ISSUE: LOW-TEMPERATURE GASIFICATION DEPOSITION $\left(<900^{\circ} \mathrm{C}\right)$

EERC Expertise (0-5): 3

Research Priority (0-5): 5

\section{Summary}

The current state of knowledge of ash-related issues in gasification systems significantly lags that for conventional combustion. The projected increasing use of gasification in advanced power systems places a high priority on increasing this understanding. Low-temperature deposition in reducing systems appears primarily sulfide-based, analogous to sulfate-based deposition in conventional systems. Iron sulfide appears to play a prominent role, although the presence of char may inhibit this. Calcium-magnesium-iron aluminosilicates and alkali species also are of significance, with water and hydrogen sulfide increasing deposit strength. Much is not yet known regarding ash partitioning, deposition mechanisms, and sintering mechanisms in these systems.

\section{Research Questions}

- The role of sulfides, particularly of vapor-phase species, as well as the presence/absence of iron sulfide in deposits.

- The sintering mechanisms for deposit growth and strength development, in particular the role of heterogeneous versus homogeneous condensation.

- The mechanisms of concentration of particular species, including heavy metals in filtration devices and on turbine blades.

\section{Applicable EERC Research \\ CABRE I \& II}

The CABRE project focused on the development of analytical techniques, production and analysis from bench-scale deposits, measurement of deposit strength, and stability of sulfides under gasification conditions. A drop-tube furnace was used to determine the size and composition distributions from five coals under gasification conditions. The viscosities of ashes were generally lower under gasification conditions relative to oxidizing conditions. Water vapor further lowered the viscosity. Strength development of low temperature deposits appeared to result from the sulfidation of already deposited ash particles. Sulfide based strength was correlated to alkali and alkaline earth elements in the ash. The formation of calcium, iron, and sodium sulfides promotes deposit strength development below $900^{\circ} \mathrm{C}$, and increases in the presence of water vapor and hydrogen sulfide. Strength increases in the presence of water vapor and hydrogen sulfide, and decreases in the presence of vapor-phase sulfides. Some evidence was found for volatile $\mathrm{FeS}$ above $800^{\circ} \mathrm{C}$. Sintering experiments were performed for varieties of coal derived ash materials under reducing conditions at low temperatures and the mechanisms of sulfide surface migrations and silicate crystallization were studied. 


\section{DRAFT}

\section{Key Literature}

Brekke, D.W.; Erickson, T.A.; Nowok, J.W.; Tibbetts, J.E.; Allan, S.E.; Benson, S.A.; Steadman, E.N. "Coal Ash Behavior in Reducing Environments (CABRE)," final report; Jan. 1995.

Scandrett, D.A.; Clift, R. "The Thermodynamics of Alkali Removal From Coal-Derived Gases," J. Inst. Energy 1984, 391-397.

Thermodynamic calculations indicate that in a reducing environment sodium and potassium will persist as vapor-phase volatile species. The calculations also suggest that aluminosilicate "getters" should remove alkalis to acceptable turbine inlet levels when reacting below $930^{\circ} \mathrm{C}$.

Brooker, D. "Chemistry of Deposit Formation in a Coal Gasification Syngas Cooler," Fuel 1993, $725,665-670$.

Initial deposition under reducing conditions in the range $300^{\circ}-556^{\circ} \mathrm{C}$ was initiated by very fine $\mathrm{FeS}$, along with minor sulfide species and halide species. The FeS content decreases from the surface into the bulk material containing primarily calcium magnesium iron aluminosilicate, calcium magnesium iron silicate, and calcium aluminosilicate. Iron and sulfur were enriched on the surface of most ash particles in the deposit.

Brooier, D.D.; Myongsook, S.O. "Iron Sulfide Deposition During Coal Gasification," Fuel Process. Technol. 1995, 44, 181-190.

Deposits in the temperature range $870^{\circ}-932^{\circ} \mathrm{C}$ consisted of particles $5-10 \mu \mathrm{m}$ diameter comprised of calcium-potassium-aluminosilicate in the more porous sintered layers and < $2 \mu \mathrm{m}$ calcium-aluminosilicate in the denser layers, both with interstitial and coatings of iron sulfide. Iron sulfide is the most likely bonding phase for the ash. The mechanism may occur by formation of iron sulfide during gasification, formation of iron sulfide from vapor-phase species during cooling, or formation from iron in the glassy ash during cooling. The first and third are believed most plausible. No sodium or calcium sulfides were observed.

Koyama, S.; Morimoto, T.; Ueda, A.; Matsuoka, H. "A Microscopic Study of Ash Deposits in a Two-Stage Entrained-Bed Coal Gasifier,” Fuel 1996, 75 4, 459-465.

Deposits collected in both high and low-temperature regimes consisted primarily of calcium-aluminosilicate, silica, and carbon. Small amounts of aluminosilicate and calcium silicate were present. Iron was present in all deposits, although no iron sulfide was found. The char carbon acted as a high-melting dispersant, preventing complete sintering and producing weak friable deposits. Although not stated, the presence of char carbon may have inhibited the formation of iron sulfide in the deposits.

Benson, S.A.; Sondreal, E.A. "Impacts of Low-Rank Coal Properties on Advanced Power Systems," in Proceedings of the Thirteenth Annual International Pittsburgh Coal Conference; Chiang, S.-H., Ed.; Vol. 1, pp 484-498.

Deposits formed in the riser and disengager of the TRDU consisted of calcium and magnesium rich coatings on the surface of the aluminosilicate bed material. The bed material appeared to react with the coal ash and sulfided dolomite to form coatings of lowmelting calcium-magnesium aluminosilicates. 


\section{DRAFT}

\section{ISSUE: ASH AND DEPOSIT RADIATIVE PROPERTIES \\ EERC Expertise (0-5): 3 \\ Research Priority (0-5): 4}

\section{Summary}

Qualitative accounts of highly reflective ash from several subbituminous coals have been invoked to explain lack of heat transfer in the lower furnace box of utility boilers. Ash emissivity strongly increases with decreasing particle size, with chemical composition having only an indirect effect. Measurements of actual surface emissivities simulating those on an actual boiler wall are difficult to recreate at bench- or pilot-scale. To date, no good prediction of ash and deposit emissivity from coal ash physical and chemical properties is available.

\section{Research Questions}

- A major unanswered research question is the prediction of ash and deposit radiative properties from coal ash chemistry and mineralogy. Although the ash chemistry and physical properties do not affect radiative properties directly, parameters such as particle size distribution and ash melting point distribution should be predictable and related to radiative properties.

\section{Applicable EERC Research}

FT-IR Spectroscopic Investigation of Fireside Deposits in A Pilot-Scale Combustor

A probe was designed for a FT-IR spectrometer to monitor deposit formation in the convective pass of a pilot-scale combustor, providing a means of monitoring infrared emissions within the furnace duct. Tests were conducted on deposits formed from Antelope subbituminous and Illinois No. 6 bituminous coals. The instrument appeared to have promise for monitoring deposit thickness. No information was obtainable on deposit chemistry, and no attempt was made to quantify deposit emissivity.

\section{Project Sodium}

Radiative and convective heat transfer from a coal-fired flame or combustion flue gas in a pilot-scale combustor were used to measure heat transfer both on a water wall and on a convective pass steam tube.

\section{CQE Project}

Research was performed in conjunction with $\mathrm{ABB}-\mathrm{CE}$ to develop heat flux degradation as a function of ash deposit thickness and other properties.

\section{Key Literature}

Zygarlicke, C. J.; McCollor, D.P.; Toman, D.L.; Wall, T.F.; Gupta, R.P.; Razaei, H. “A Comparison of Ash Produced under Conventional and Low $\mathrm{NO}_{\mathrm{x}}$ Combustion Conditions," Presented at the International Joint Power Generation Conference \& Exposition, Minneapolis, MN, Oct. 1996.

Entrained fly ash has been produced from a bituminous, a subbituminous, and a lignite coal under both conventional and low- $\mathrm{NO}_{\mathrm{x}}$ conditions. These were collected and examined by scanning electron microscopy to compare structural and mineral composition. The major effect of low- $\mathrm{NO}_{\mathrm{x}}$ conditions on fly ash composition appears to be a decrease in the amount of pure mineral phases present, with a concurrent increase in amorphous and mixed mineral 


\section{DRAFT}

phases. Preliminary sizing results also indicates an increase in ash mean particle size under low- $\mathrm{NO}_{\mathrm{x}}$ conditions for the three coals tested. Particle size and chemistry differences of the fly ash produced from conventional and low- $\mathrm{NO}_{\mathrm{x}}$ combustion were evaluated for impacts on ash emissivity.

Wall, T.F.; Bhattacharya, S.P.; Zhang, D.K.; Gupta, R.P.; He, X. "The Properties and Thermal Effect of Ash Deposits in Coal-Fired Furnaces: A Review," Prog. Energy Combust. Sci. 1993, 19, 487-504.

The properties influencing heat transfer, absorptivity, and thermal conductivity are shown from many measurements to depend on the processes by which deposits form and react internally and with furnace gasses. The literature values of properties depend principally on the physical ash character and whether the deposits are particulate or are sintered or fused. Bounds for the range of properties and expected variations with temperature and deposit porosity and other physical properties are suggested and compared with those for pure oxides and salts. Theoretical predictions of radiative properties are shown to predict trends with temperature and particle size for ash and the observed transfer to higher emittance values for slags formed at higher temperatures. The significance of the variation of these properties on radiative transfer is quantified using mathematical modeling of furnaces.

Zygarlicke, C.J.; Benson, S.A.; Borio, R.W. "Pilot- and Bench-Scale Combustion Testing of a Wyoming Subbituminous/Oklahoma Bituminous Coal Blend," in Coal-Blending and Switching of Low-Sulfur Western Fuels; Bryers, R.W.; Harding, N.S., Eds.; American Society of Mechanical Engineers: New York, 1994; pp 281-300.

Heat transfer measurements through waterwall panels showed differences based on deposit composition and thickness as determined by different blends of Wyoming subbituminous coal and Oklahoma bituminous coal.

Benson, S.A.; Jones, M.L.; Kalmanovitch, D.P.; Steadman, E.N. "In Situ Determination of Temperature Distributions in Ash Deposits in a Pilot-Scale Furnace," Presented at the Engineering Foundation Conference on Mineral Matter and Ash Deposition from Coals, Santa Barbara, CA, 1988.

The paper is a summation of the in-situ deposit temperature measurement study performed under Project Sodium.

Benson, S.A.; Hurley, J.P.; Jones, M.L.; Kalmanovitch, D.P.; Ness, S.R.; Nowok, J.; Puffe, W.; Ramanathan, R.; Steadman, E.N.;, Toman, D.L.; Zygarlicke, C.J. "Project Sodium: Follow-On Work to the Original Evaluation of Sodium Effects in Low-Rank Coal Combustion Systems," final technical report and executive summary; EERC publication, Jan. 1992.

Gupta, R.P.; Wall, T.F. "The Thermal Conductivity of Ash Deposits: Particulate and Slag Structures," In Proceedings of Engineering Foundation Conference on Impact of Mineral Impurities in Solid Fuel Combustion; Kona, HI, Nov. 2-7, 1997; Wall, T.F.; Baxter, L.L., Eds.

Goetz, G.J.; Nsakala, N.Y.; Borio, R.W. "Development of Method for Determining Emissivities and Absorptivities of Coal Ash Deposits," J. Eng. for Power 1979, 101, 607-614. 


\section{DRAFT}

Measurement techniques used to measure radiative properties of deposits involved spectral scans of ash deposits compared with a black body. Deposits were not grey bodies, meaning their emissivity and absorptivity were a function of temperature. Measured emissivities ranged from 0.4 to 0.9 , and were higher for eastern coal than for western coal, and for fused deposits compared to powdery ash.

Wall, T.F.; Becker, H.B. "The Total and Spectral Emissivities of Particulate Coal Ashes," Fouling and Slagging Resulting from Impurities in Combustion Gases; Bryers, R.W., Ed.; Engineering Foundation: New York, 1983; pp 211-224.

The spectral emissivities of coal ashes decrease with increasing temperature, indicating that the ash does not behave as a grey body. For deposits on furnace walls, absorbed radiation should be calculated based on the absorptivity predicted for the high-temperature incident radiation rather than the higher absorptivity value for the deposit temperature. Low-rank coals show the same qualitative radiative properties as high-rank coals. Data for Australian coals are presented.

Wall, T.F.; Becker, H.B. "Total Absorptivities and Emissivities of Particulate Coal Ash from Spectral Band Emissivity Measurements," J. Eng. for Gas Turbines and Power 1984, 106 (4), 771-776.

Previous measurements of the spectral emissivity of coal ashes were converted to total absorptivities and emissivities. Below the temperature at which ash sinters, the total absorptivity of an ash layer-which is necessary to estimate radiant heat transfer-is shown to depend on both the flame temperature and the ash temperature. Synthetic mixtures of the oxides $\mathrm{Al}_{2} \mathrm{O}_{3}, \mathrm{SiO}_{2}$, and $\mathrm{Fe}_{2} \mathrm{O}_{3}$ are shown to ogive the same trends as those for ashes with the same $\mathrm{Fe}_{2} \mathrm{O}_{3}$ content.

Lowe, A. "The Radiative Properties and Effects of Fly Ash Particles," Pulverized Coal Firing Mineral Matter and Its Effects; University of Newcastle, NSW, Australia: 1979; pp L7.1-8.

Fly ash in combustion gas contributes significantly to radiant heat transfer, particularly if water vapor content is low. For short optical paths such as platen zones, scattering effects are negligible and high fly ash loadings increase heat transfer. For longer path lengths, scattering reduces radiant transmission more than fly ash emissivity increases it, and overall heat transfer is reduced.

Smith, J.D.; Smith, P.J.; Smoot, L.D.; Rees, D.P. "Part I. Prediction of the Effects of Coal Quality on Utility Furnace Performance," Third Engineering Foundation Conference on Slagging and Fouling Due to Impurities in Combustion Gases, Copper Mountain, CO, July 1984; Preprint, $40 \mathrm{p}$.

A single-zone model was developed to predict heat transfer and thermal efficiency of the furnace volume in a boiler. The three most important coal-related parameters were deposit thickness, thermal conductivity, and surface emittance. Thermal efficiency was reduced significantly by wall deposits. Thermal efficiency increased with deposit conductivity increase, and to a lesser degree with emissivity. High ash content also reduced efficiency due to sensible heat loss. 


\section{DRAFT}

Wall, T.F.; Wibberley, L.J. "Combustion, Temperature, and Heat Transfer in Pulverized CoalFired Boilers. Part I - Combustion and Radiative Mechanisms and Mineral Matter," Pulverized Coal Firing Mineral Matter and Its Effects; University of Newcastle, NSW, Australia: 1979; pp L5.1-14.

Radiant emitters in pulverized fuel furnaces include large particles of char and ash, small particles of soot or sublimate, and triatomic gases. Radiant interchange can be calculated for subzones of volume and area. Heat absorption is reduced by $30 \%$ to $70 \%$ by ash deposits of 4 to $25 \mathrm{~mm}$ thickness. Devolatilization occurs in less than 20 milliseconds; char burnout is slower and may be either chemically or diffusionally controlled. Reducing conditions in burning char produce corrosive $\mathrm{FeS}$ and volatile $\mathrm{SiO}$. 


\title{
DRAFT
}

\author{
ISSUE: ASH AND DEPOSIT THERMAL CONDUCTIVITY PROPERTIES \\ EERC Expertise (0-5): 3 \\ Research Priority (0-5): 4
}

\section{Summary}

Deposit thermal conductivity has been experimentally determined at the bench, pilot, and fullscale levels for a variety of coal fuels. As with deposit radiative properties, the chemical composition of the ash is only indirectly related to the deposit thermal conductivity. The conductivity is strongly dependent on deposit particle size, porosity, and degree of sintering. Further, deposit conductivity exhibits hysteresis, that is once the deposit conductivity increases due to sintering or slagging at elevated temperature, the conductivity does not decrease to the unsintered level again at lower temperature. Prediction of deposit conductivity is difficult, requiring knowledge of the thermal history of the deposit as well as an estimation of the change in deposit physical properties with temperature.

\section{Research Questions}

- The major unanswered research question is the prediction of deposit conductivity from deposit or coal chemistry. This in turn requires the ability to predict deposit physical properties, including the degree of sintering, based on the thermal history of the deposit. Inclusion of a prediction of deposit thermal conductivity in a model will be difficult without involving a mechanistic model accounting for deposit temperature history.

\section{Applicable EERC Research Project Sodium}

Deposit temperature profiles were obtained as deposits were formed during pilot-scale combustion tests of four lignite coals. Seven thermocouples were arrayed on a probe simulating a heat-exchange tube surface. The results showed a consistent drop in temperature in the interior of the deposits as they grew. In all cases, deposit thicknesses of only a few millimeters resulted in a significant reduction in heat transfer to the probe. Relative thermal conductivities were calculated for the deposits, with the estimate of absolute thermal conductivity close to literature values.

\section{Key Literature}

Mulcahy, M.F.R.; Boow, J.; Gould, P.R.C. "Fireside Deposits and Their Effect on Heat Transfer in a Pulverized-Fuel-Fired Boiler. Part I. The Radiant Emittance and Effective Thermal Conductance of the Deposits,"

The total and spectral emittances and effective thermal conductances of fireside deposits were measured at temperatures to $1150^{\circ} \mathrm{C}$. The values were strongly dependent on the temperature and thermal history of the material. The thermal conductances showed a large increase when sintering occurred. The conductance of solidified slag was similar to that of the sintered deposit after fusion. The deposits behave as fusible particulate material which are partly transparent to infrared radiation, and the effect of fusion on both emittance and conductance is due to the greater transparency of the fused material. 


\section{DRAFT}

Wall, T.F.; Bhattacharya, S.P.; Zhang, D.K.; Gupta, R.P.; He, X. "The Properties and Thermal Effect of Ash Deposits in Coal-Fired Furnaces: A Review" Prog. Energy Combust. Sci. 1993, 19, 487-504.

The properties influencing heat transfer, absorptivity, and thermal conductivity are shown from many measurements to depend on the processes by which deposits form and react internally and with furnace gasses. The literature values of properties depend principally on the physical ash character and whether the deposits are particulate or are sintered or fused. Bounds for the range of properties and expected variations with temperature and deposit porosity and other physical properties are suggested and compared with those for pure oxides and salts. Theoretical predictions of radiative properties are shown to predict trends with temperature and particle size for ash and the observed transfer to higher emittance values for slags formed at higher temperatures. The significance of the variation of these properties on radiative transfer is quantified using mathematical modeling of furnaces.

Benson, S.A.; Jones, M.L.; Kalmanovich, D.P.; Steadman, E.N. "In Situ Determination of Temperature Distributions in Ash Deposits in a Pilot-Scale Furnace," Presented at the Engineering Foundation Conference on Mineral Matter and Ash Deposition from Coals, Santa Barbara, CA, 1988.

The paper is a summation of the in-situ deposit temperature measurement study performed under Project Sodium.

Gupta, R.P.; Wall, T.F. “The Thermal Conductivity of Ash Deposits: Particulate and Slag Structures," In Proceedings of Engineering Foundation Conference on Impact of Mineral Impurities in Solid Fuel Combustion; Kona, HI, Nov. 2-7, 1997; Wall, T.F.; Baxter, L.L., Eds.

The thermal conductivity of ash deposits were compared to powders a porous materials. Particulate based material versus slag types of material have distinct differences in conductivity properties. Particle and pore sizes are important parameters in radiation models. Theoretical estimates and experimental data of thermal properties of well characterized materials are compared. 


\section{COMPUTED VARIABLES FOR HOPPER MODEL AND MODIFIED FRENKEL MODEL}




\section{TABLE B-1}

Computed Variables for Hopper Model

\begin{tabular}{c|c}
\hline$(\gamma \mathrm{t}) /\left(\eta \mathrm{r}_{\mathrm{f}}\right)$ & $\left(\mathrm{x} / \mathrm{r}_{\mathrm{f}}\right)$ \\
\hline 0 & 0 \\
0.00135 & 0.00355 \\
0.00297 & 0.0071 \\
0.00860 & 0.0181 \\
0.01986 & 0.0372 \\
0.0331 & 0.0574 \\
0.0483 & 0.0787 \\
0.0656 & 0.1013 \\
0.0851 & 0.1253 \\
0.1071 & 0.1509 \\
0.1321 & 0.1782 \\
0.1604 & 0.2075 \\
0.1927 & 0.2391 \\
0.2299 & 0.2734 \\
0.2731 & 0.3106 \\
0.3239 & 0.3515 \\
0.3848 & 0.3967 \\
0.4595 & 0.4472 \\
0.5542 & 0.5046 \\
0.6809 & 0.5713 \\
0.8660 & 0.6520 \\
1.1946 & 0.7577 \\
1.4426 & 0.8147 \\
1.6417 & 0.8501 \\
1.9845 & 0.8955 \\
2.5839 & 0.9438 \\
3.1325 & 0.9676 \\
3.7342 & 0.9825 \\
4.2836 & 0.9900 \\
5.4348 & 0.9968 \\
& 1.0000 \\
\hline &
\end{tabular}




\section{TABLE B-2}

Computed Variables for Modified Frenkel Model

\begin{tabular}{c|c}
\hline$(\gamma \mathrm{t}) /\left(\eta \mathrm{r}_{\mathrm{o}}\right)$ & $(\mathrm{x} / \mathrm{r})$ \\
\hline 0.0001 & 0.0100 \\
0.01 & 0.0979 \\
0.02 & 0.1396 \\
0.03 & 0.1713 \\
0.04 & 0.1984 \\
0.05 & 0.2210 \\
0.06 & 0.2419 \\
0.07 & 0.2609 \\
0.08 & 0.2786 \\
0.09 & 0.2949 \\
0.10 & 0.3109 \\
0.20 & 0.4274 \\
0.30 & 0.5060 \\
0.40 & 0.5736 \\
0.50 & 0.6242 \\
0.60 & 0.6721 \\
0.70 & 0.7062 \\
0.80 & 0.7403 \\
0.90 & 0.7666 \\
1.00 & 0.7910 \\
1.50 & 0.8767 \\
2.00 & 0.9241 \\
4.00 & 0.9872 \\
6.00 & 0.9976 \\
\hline .00 & 0.9995 \\
\hline & \\
\hline & \\
\hline
\end{tabular}

